\title{
Austria: Financial Sector Stability Assessment
}

This Financial Sector Stability Assessment on Austria was prepared by a staff team of the International Monetary Fund as background documentation for the periodic consultation with the member country. It is based on the information available at the time it was completed on August 19, 2013. The views expressed in this document are those of the staff team and do not necessarily reflect the views of the government of Austria or the Executive Board of the IMF.

The policy of publication of staff reports and other documents by the IMF allows for the deletion of market-sensitive information.

Copies of this report are available to the public from

International Monetary Fund • Publication Services $70019^{\text {th }}$ Street, N.W. • Washington, D.C. 20431

Telephone: (202) 623-7430 • Telefax: (202) 623-7201

E-mail: publications@imf.org Internet: http://www.imf.org

Price: $\$ 18.00$ a copy

International Monetary Fund Washington, D.C. 


\section{INTERNATIONAL MONETARY FUND}

\section{AUSTRIA}

\section{FINANCIAL SYSTEM STABILITY ASSESSMENT}

August 19, 2013

Approved By

Reza Moghadam and

Ceyla Pazarbasioglu

Prepared By

The Monetary and Capital

Markets Department
The 2013 Austria FSAP team was led by Nicolas Blancher and comprised Jianping Zhou, Atilla Arda, Paul Mathieu, David Parker, Mustafa Saiyid, Siegfried Steinlein, Laura Valderrama, Michael Deasy, Michael Hafeman, and Arnoud Vossen.

- The 2008-2009 crisis led to significant financial sector distress in Austria, due to strains that developed both domestically and in Central Europe and South Eastern Europe (CESEE), where Austrian banks have a systemic role.

- Austrian banks appear well positioned to comply with Basel III requirements, but they need capital buffers above these new norms given their particular risk profiles, and will have to repay government capital.

- The global crisis revealed weaknesses in Austria's financial stability policy framework, and recent changes at the European levels provide an opportunity to address these. In particular, establishing a full-fledged framework for bank resolution would allow Austria to deal with failing banks in an orderly and leastcost way. 


\section{CONTENTS}

GLOSSARY

MACROFINANCIAL BACKGROUND

A. Macroeconomic Background____ 9

B. Financial System Structure___ 9

C. Recent Crisis Experience and Policy Response___ 11

FINANCIAL STABILITY _ 12

A. Financial Soundness _ 12

B. Stress Tests _ـ 16

C. Summary Assessment _ 19

FINANCIAL OVERSIGHT _ 21

A. Banking Oversight _ 22

B. Insurance Oversight _ 23

C. Macroprudential Perspective ___ 24

D. Anti-money Laundering and Combating the Financing of Terrorism (AML/CFT)__ 24

CRISIS PREVENTION _ 25

A. Early Intervention and Liquidity Support __ 25

B. Bank Resolution Framework___ 26

C. Deposit Insurance Scheme __ 27

SYSTEMIC CRISIS MANAGEMENT__ 28

\section{BOXES}

1. Supervisory Guidance on Strengthening the Sustainability of the Business Models of Large Internationally Active Austrian Banks __ 12

2. Asset Quality of Austrian Banks in CESEE Countries __ 13

\section{FIGURES}

1. Market Shares in Banking Sector 10

2. Share of Banks' Assets and Profits in CESEE __ 10

3. Asset Growth in CESEE__ 11 
4. NPL Trends in Austrian Banks Subsidiaries __ 13

5. NPLs Coverage in CESEE _ 13

6. Foreign Currency Lending to CESEE Households __ 14

7. Funding Structure__ 14

8. Breakdown of Operating Income (consolidated basis)__ 15

9. Capitalization Ratios_Peer Banks ___ 15

10. Key Components of the FSAP Stress Tests ___ 17

11. Drivers of Changes in CT1 for the Whole Banking System __ 18

12. Five-year CDS Spreads _ 20

13. Select Euro Area Countries: Bank Branches and Employees per 10000 Inhabitants ___ 21

14. Recent Economic Developments ___ 33

15. Sectoral Debt__ 34

16. Selected Financial Market Indicators __ 35

17. Banking Sector FSI Peer Comparison___ 36

18. Solvency Stress Test Results—CT1 Capital Buckets___ 37

19. Solvency Stress Test Results_CT1 Ratio Distribution ___ 38

20. Capital Adequacy Ratios_Sensitivity Analysis___ 39

21. Systemic Risk in the CESEE Region __ 40

22. Structure of Product Categories of RPVs _ 51

\section{TABLES}

1. FSAP_Key Recommendations___ 8

2. Selected Economic Indicators, 2007-2014__ 29

3. Vulnerability Indicators, 2007-2012___ 30

4. Financial System Structure___ 30

5. Financial Soundness Indicators (FSIs) __ 31

6. Soundness Indicators for the Insurance Sector __ 32

7. Breakdown of RPV's Funding Gap by Product Category ___ 51

8. Stress Test for RPV Yield and CHF Shock by Product Category___ 52

\section{APPENDIXES}

I. Implementation of the Key Recommendations of 2007 FSAP Update____ 41

II. Risk Assessment Matrix (RAM)___ 43

III. Stress Test Matrix (STeM) For the Banking Sector____ 45

IV. Risks to the Financial Sector from Repayment Vehicles__ 50

\section{ANNEX}

I. Report on the Observance of Standards and Codes-Basel Core Principles-Summary 


\section{GLOSSARY}

AFS

AML/CFT

BIS

CAR

CCP

CD

CDS

CESEE

$\mathrm{CHF}$

CIS

$\mathrm{CP}$

DGS

EDF

EEA

ELA

FATF

$\mathrm{FCL}$

FIMBAG

FinStaG

FMK

FSAP

$\mathrm{FCL}$

G-SIFI

IAIS

LCFI

LCR

LRV

LGD

LLP

MoF

MoU

MPO

MTM

NBFI

NCB

NPL

PCA

RPV
Available for Sale

Anti-Money Laundering/Combating the Financing of Terrorism

Bank for International Settlements

Capital Adequacy Ratio

Central Counterparty

Certificate of Deposit

Credit Default Swap

Central Europe and South Eastern Europe

Swiss Franc

Commonwealth of Independent States

Commercial Paper

Deposit Guarantee Scheme

Expected Default Frequency

European Economic Area

Emergency Liquidity Assistance

Financial Action Task Force

Foreign currency loan

Federal Corporation of Financial Market Participation

Federal Act on Measures to Stabilize the Financial Market

Financial Market Committee

Financial Sector Assessment Program

Foreign Currency Loans

Global Systemically Important Financial Institution

International Association of Insurance Supervisors

Large and Complex Financial Institution

Liquidity Coverage Ratio

Loans with Repayment Vehicles

Loss given Default

Loan loss provisions

Ministry of Finance

Memorandum of Understanding

Macroprudential Oversight

Mark to Market

Nonbank Financial Institutions

National Central Bank

Non-Performing Loan

Prompt Corrective Action

Repayment Vehicle 
RWA

SIFI

SME

SSM

$\mathrm{VaR}$
Risk Weighted Assets

Systemically Important Financial Institutions

Small- and Medium-Sized Enterprise

Single Supervisory Mechanism

Value at Risk 


\section{EXECUTIVE SUMMARY}

The 2008-09 global financial crisis exerted significant pressure on Austria's financial system. Substantial liquidity and capital support was provided by the government, and three mid-sized domestic banks were fully or partly nationalized. However, Austrian banks on the whole have benefited from limited exposures to sovereign and market risks, a stable funding structure, and relatively favorable macroeconomic conditions. In CESEE countries, Austrian banks have not resorted to large-scale deleveraging, notwithstanding somewhat weaker growth, recent volatility, and rising vulnerabilities, including high and rising NPLs. The authorities responded to the crisis by enhancing financial oversight and encouraging better risk management in the industry.

Austria's banking system is still facing strains. Bank asset quality is deteriorating and difficult to assess with full confidence owing to shortcomings in data on CESEE exposures. Foreign-currency loans (FCL) remain important, both domestically and in CESEE, and bank profitability has declined due to falling interest margins and higher provisions against non-performing loans. Bank capital ratios are improving, but include a significant share of public participation, and remain slightly below peers. The low interest rate environment has hurt profitability of life insurance companies.

Stress test results indicate that under adverse medium-term scenarios, virtually all Austrian banks, including all internationally-active institutions, would meet regulatory capital requirements (taking into account Basel III implementation), and are resilient to funding and contagion risks. However, these results need to be interpreted with caution given the asset quality data limitations noted above. The upcoming bank asset quality reviews by the ECB should provide a more robust basis for assessing the strength of the balance sheets of Austrian banks and the policy responses that may be needed. More broadly, there is no room for complacency in the current environment, and Austrian banks will need to build stronger capital buffers above regulatory requirements, including in order to repay government capital and meet market expectations. As regards small and medium-size banks, further efficiency gains will be required over the medium-term given the low-profitability domestic environment.

The Austrian Financial Market Authority (FMA) and the central bank (OeNB) collaborate effectively in performing banking supervision, including on a cross-border basis. Nevertheless, some further improvements should be pursued, such as in strengthening FMA governance, cross-border information exchanges, governance standards in the banking industry, and the FMA's supervisory tools and powers for corrective action. The top eight Austrian banks are expected to fall under direct supervision of the European Central Bank (ECB), and preparations are underway to support the implementation of a Single Supervisory Mechanism (SSM).

The FMA also performs well in supervising insurers and pension funds. It should continue to prepare itself and the industry for Solvency II, and to further improve its observance of international best practices in this area, including as relates to cross-sector collaboration, prudential rules, and industry governance requirements. 
Regarding macroprudential policy, priorities include setting up an authority with a clear policy mandate, with the OeNB playing a leading role in close coordination with the Ministry of Finance (MOF) and the FMA at the national level, and the European Systemic Risk Board (ESRB) and ECB at the European level. The need for macroprudential policy instruments that go beyond those included in forthcoming European Union (EU) Directives should be considered.

As highlighted by recent experience during the crisis, Austria needs to put in place a special bank resolution regime to resolve problem banks in a manner that does not endanger financial stability or fiscal sustainability. While the authorities prefer to await the formal adoption of the EU Directive on bank recovery and resolution, it would be in Austria's interest to swiftly introduce a full-fledged bank resolution framework, with a wide range of tools and powers-based on international best practices and consistent with the proposed EU directive-and strengthened resolution arrangements with non-EU countries. The FMA should become Austria's bank resolution authority.

While the current Deposit Guarantee Scheme (DGS) has certain benefits, the authorities should use the opportunity of the forthcoming EU DGS Directive to introduce a unified DGS. Specifically, an ex ante-funded and publicly-administered national DGS would improve risk pooling, transparency and DGS fund management, and prompt payout. A high-level working group should be tasked with designing the new DGS, taking the EU Directive as well as the Basel Committee on Banking Supervision (BCBS) Core Principles for Effective Deposit Insurance Schemes as minimum standards.

The framework governing the OeNB's finances in general, and Emergency Liquidity Assistance (ELA) operations in particular, could be improved to maintain the right balance between financial stability and OeNB's financial autonomy. The mandate of the Federal Corporation of Financial Market Participation (FIMBAG) and the conditions under which capital support is provided to distressed banks should also be strengthened to increase FIMBAG's role in overseeing and negotiating bank restructuring plans. 
Table 1. FSAP—Key Recommendations

\begin{tabular}{|c|c|}
\hline Recommendations & Priority * \\
\hline \multicolumn{2}{|l|}{ Macroprudential Oversight } \\
\hline $\begin{array}{l}\text { Set up a macroprudential authority with a clear legal mandate for policy formulation and rule- } \\
\text { making, chaired by the OeNB, and coordinating with the FMA, ESRB and ECB }\end{array}$ & High \\
\hline $\begin{array}{l}\text { Consider expanding the range of policy tools beyond those envisaged under the CRR/CRD (e.g., } \\
\text { structural measures, LTV, and DTI ratios) }\end{array}$ & Medium \\
\hline \multicolumn{2}{|l|}{ Banking Oversight } \\
\hline Strengthen FMA's governance, including legal protection of its bodies and staff & High \\
\hline $\begin{array}{l}\text { Promote stronger governance in the industry, e.g., through more systematic fit and proper tests } \\
\text { and requirements for compliance and CRO functions }\end{array}$ & Medium \\
\hline $\begin{array}{l}\text { Enhance some of the FMA's supervisory powers related to prior approval, recovery and resolution } \\
\text { plans, and corrective action, including through general rule-making authority }\end{array}$ & Medium \\
\hline $\begin{array}{l}\text { Continue to actively prepare for SSM implementation, including to mitigate operational risks } \\
\text { during the transition and ensure effective coordination }\end{array}$ & High \\
\hline \multicolumn{2}{|l|}{ Insurance and Pension Oversight } \\
\hline $\begin{array}{l}\text { Further prepare for Solvency II implementation and improve the solvency regime in line with } \\
\text { international best practice. }\end{array}$ & Medium \\
\hline $\begin{array}{l}\text { Further develop and enhance the use of risk-rating and stress-testing methodologies, and more } \\
\text { frequent on-site inspections }\end{array}$ & Medium \\
\hline \multicolumn{2}{|l|}{ Early Intervention/Bank Resolution Frameworks } \\
\hline $\begin{array}{l}\text { Enhance the proposed early intervention framework by better identifying the required powers and } \\
\text { widening the range of intervention tools }\end{array}$ & Medium \\
\hline $\begin{array}{l}\text { Introduce a bank resolution framework based on international best practice, consistent with future } \\
\text { EU Directives, and assign FMA as the resolution authority }\end{array}$ & High \\
\hline Strengthen cross-border resolution arrangements with non-EU/EEA countries & Medium \\
\hline \multicolumn{2}{|l|}{ Deposit Guarantee Scheme } \\
\hline $\begin{array}{l}\text { Introduce a unified, ex ante-funded, public DGS, using the BCBS Core Principles and EU Directive } \\
\text { as minimum standards }\end{array}$ & Medium \\
\hline Establish a high-level working group to design and organize the transition to the unified DGS & High \\
\hline \multicolumn{2}{|l|}{ Systemic Crisis Management } \\
\hline $\begin{array}{l}\text { Strengthen crisis preparedness, including by ensuring that FinStaG resources are adequate and } \\
\text { giving the Federal Government standing authorization to take necessary action }\end{array}$ & Medium \\
\hline $\begin{array}{l}\text { Enhance FIMBAG's role in negotiating and overseeing the implementation of bank restructuring } \\
\text { plans for which the Federal Government provides capital support }\end{array}$ & High \\
\hline
\end{tabular}

* The level of priority broadly reflects the recommended timeframe for implementation (high priority: within a year; medium priority: within 1 to 3 years). 


\section{MACROFINANCIAL BACKGROUND}

\section{A. Macroeconomic Background}

1. The lackluster economic recovery has weighed on bank credit. Credit growth had recovered from post-crisis lows but decelerated again since mid-2012 and stood at 0.4 percent $(y-0-y)$ at the beginning of 2013. This appears to have mainly been driven by weak credit demand, although survey results suggest some tightening of credit conditions by banks. The most robust loan segments were in the retail and commercial mortgage sectors, mirroring strong housing demand and price developments in some major Austrian cities and selected tourist areas, notwithstanding limited data availability on real estate prices.

\section{Private debt ratios in the Austrian economy are moderate relative to other euro area} countries, but public debt has increased significantly during the crisis (Figure 15). Corporate debt level hovers around the euro area median, and the Austrian corporate sector is well diversified and competitive, with Germany, the CESEE, and Italy as the main trading partners. ${ }^{1}$ Household debt is lower than for the euro area average, but includes a higher share of foreign currencydenominated debt (predominantly in Swiss francs) and housing loans with variable interest rate loans in housing loans. Public sector debt increased by almost 15 percentage points since 2007, to about 74 percent of GDP at end-2012.

\section{B. Financial System Structure}

3. The financial system is dominated by a large banking sector (Table 4). After a decade of rapid expansion, especially in CESEE countries, the banking sector is large (about 350 percent of GDP and 80 percent of total financial system assets). There are more than 800 banking institutions, but the three largest (Erste, Raiffeisen and UniCredit Bank Austria) account for almost half of total bank assets. $^{2}$

\footnotetext{
${ }^{1}$ The acronym CESEE stands for Central Europe and South Eastern Europe. It includes new EU member states in 2004: Czech Republic, Estonia, Hungary, Latvia, Lithuania, Poland, Slovakia, Slovenia; new EU member states in 2007: Bulgaria, Romania; countries in South-Eastern Europe: Albania, Bosnia and Herzegovina, Croatia, Kosovo, Macedonia, Montenegro, Serbia, Turkey; and Commonwealth of Independent States: Armenia, Azerbaijan, Belarus, Georgia, Kazakhstan, Kyrgyzstan, Moldova, Russia, Tajikistan, Turkmenistan, Ukraine, Uzbekistan.

${ }^{2}$ Non-bank financial institutions hold assets amounting to $€ 300$ billion. They include over 2,000 mutual funds ( $€ 147$ billion) and 50 insurance companies ( $€ 108$ billion). Austria's pension system is heavily dominated by the public pay-as-you-go pension system, and occupational pension plans only hold $€ 16$ billion in assets.
} 


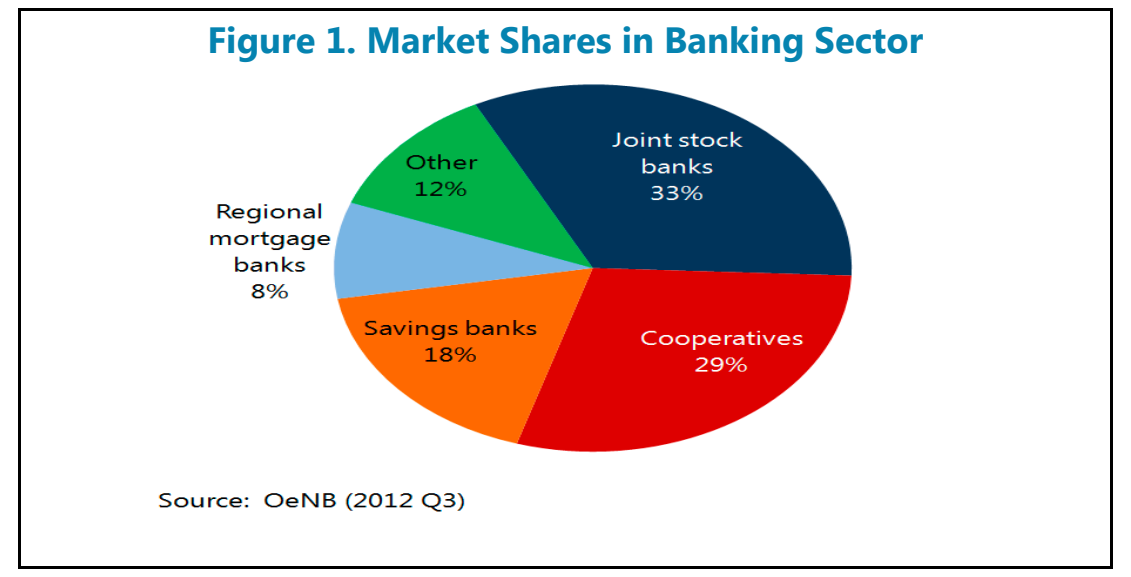

4. The banking system is characterized by extensive cross-border operations, especially in the CESEE region. Partly due to historical links in the region, Austrian banks expanded through an extensive network of local subsidiaries. ${ }^{3}$ CESEE activities have been more profitable than domestic activities, contributing to about 50 percent of total profits since the crisis while representing less than one-quarter of total bank assets (Figure 2). Within CESEE countries, Austria's banking system is the main common lender and plays a "gatekeeper" role, ${ }^{4}$ with market shares above one-third in the Czech Republic, Croatia, Romania, Slovakia and Bosnia. Austria is also a host country for foreign banking groups, which represent more than 20 percent of total bank assets in Austria and are dominated by UniCredit Bank Austria AG, BAWAG, and Sberbank Europe.

Figure 2. Share of Banks' Assets and Profits in CESEE

(in billions)

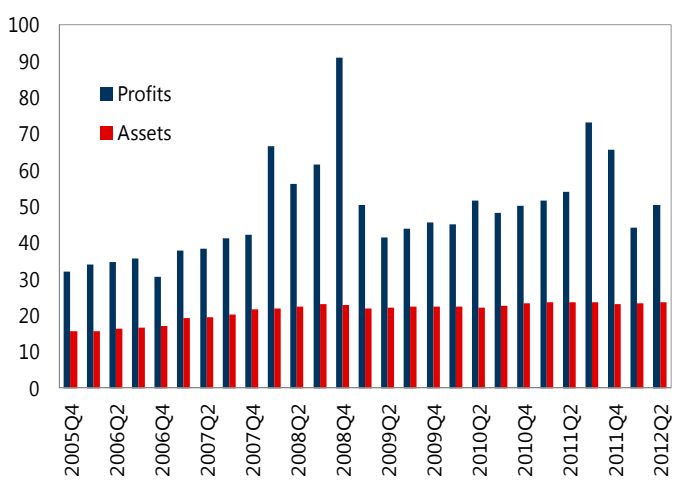

Source: OeNB

5. The insurance industry has gone through a period of consolidation and also acquired a large presence in CESEE. Over the past 15 years, the number of Austrian insurance companies declined by about 20 percent, and at present, two domestic companies represent nearly half of the market. Life insurance companies accounted for more than two thirds of total assets in the sector. After decades of expansion in the CESEE region, a third of their income is now generated in this region.

\footnotetext{
${ }^{3}$ Direct and cross-border foreign lending exposures amount to $€ 513$ billion in 2012 (44 percent of overall banking system assets), of which $€ 326$ billion (105 percent of GDP) are to the CESEE region. The largest internationally-active banks account for about 80 percent of these exposures.

${ }^{4}$ See Enhancing Surveillance: Interconnectedness and Clusters, 2012, and 2012 Spillover Report-Background Papers.
} 


\section{Recent Crisis Experience and Policy Response}

6. The 2008-09 crisis led to financial sector distress in Austria. The high CESEE exposures of its internationally-active banks weakened market confidence and boosted borrowing costs for both Austrian banks and the sovereign (Figure 16). Three medium-sized banks fell into serious distress and have been relying on repeated government financial support since the crisis. Their restructuring has been slow. Austrian banks have been affected by the European sovereign debt crisis to a lesser degree than the banks in other Euro area countries. ${ }^{5}$

7. Large scale deleveraging by Austrian banks away from CESEE countries has not materialized. During 2008-2012, Austrian banks have marginally increased their aggregate asset exposure to CESEE countries (by about $€ 11$ billion), but reallocated their exposures in the region (Figure 3). Austrian bank subsidiaries in CESEE have also partly replaced cross-border funding with local funding in recent years, although their dependence on intra-group funding remains significant.

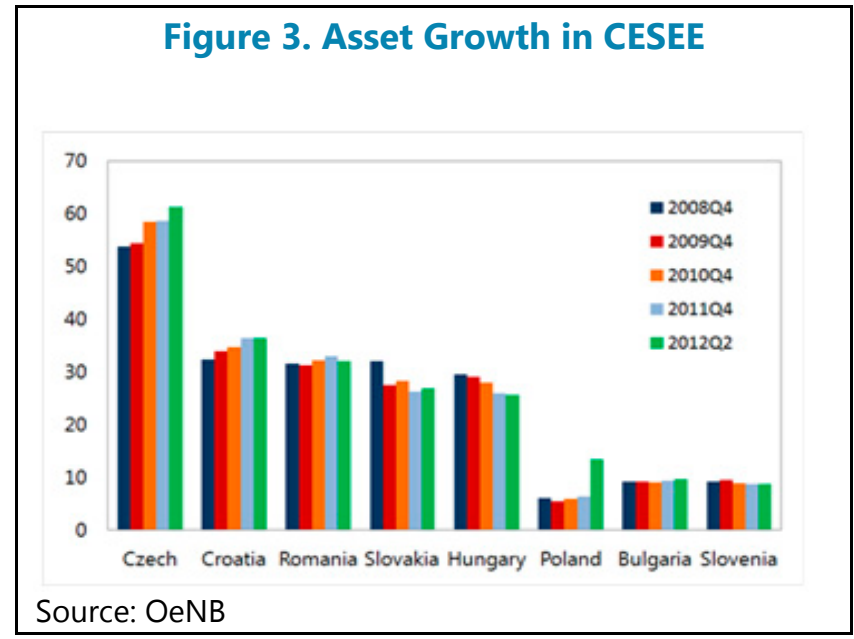

8. In response to the crisis, the authorities took several steps to support the banking system and to strengthen financial oversight. Many of these were in line with the 2007 FSAP recommendations (Appendix II). They include:

- Capital support and funding guarantees. The October 2008 "banking package" included: $€ 15$ billion for bank recapitalization measures; up to $€ 75$ billion of bank funding guarantees; and unlimited deposit insurance until end-2009. A federal entity was created to manage public participations in the banking system.

- $\quad$ Foreign currency liquidity risk management. Measures were introduced in late 2008 to better monitor and contain FC liquidity risks, by encouraging banks to diversify FC funding sources across counterparties and instruments, and lengthen FC funding tenors.

- Supervisory reforms. Cooperation between the FMA and the OeNB was strengthened, including by establishing a Financial Market Committee (FMK). New supervisory guidance was issued for the three largest internationally-active Austrian banks (Box 1).

- Cross-border collaboration. Austria has been an active participant in the Vienna Initiative aiming to bolster coordination among home and host country authorities and avoid disorderly deleveraging.

\footnotetext{
${ }^{5}$ Their combined sovereign exposures to Spain, Portugal, Italy, Ireland, and Greece were halved to about 1 percent of GDP over the last three years.
} 
Box 1. Supervisory Guidance on Strengthening the Sustainability of the Business Models of Large Internationally Active Austrian Banks

The new supervisory guidance for the largest three Austria-based banks issued on March 14, 2012 consists of three pillars:

- Higher capital buffers. Basel III capital rules regarding CET1 capital were to be fully implemented by January 1, 2013 without transitional provisions, except regarding private and government participation capital issued under the Austrian bank support act (which will initially be included in CET1 capital and phased out according to CRR/CRD IV).

- Promotion of stable local funding of subsidiaries. To encourage more reliance on local funding by Austrian bank subsidiaries, a Loan-to-Local-Stable-Funding-Ratio (LLSFR) was introduced (defined as loans to non-banks divided by local stable funding). The subsidiaries were encouraged to reduce it below 110 percent.

- Recovery and resolution plans. Parent banks were required to submit these plans by end-2012.

\section{FINANCIAL STABILITY}

\section{A. Financial Soundness}

9. Bank asset quality on a consolidated basis is deteriorating, and is difficult to assess with full confidence owing to shortcomings in data on CESEE exposures. The NPL ratio for Austrian banks' domestic operations has remained stable at about $4 \frac{1}{2}$ percent in past years, albeit slightly above peer country average (Table 5). However, the NPL ratio for the banks' consolidated balance sheets is above 9 percent, ${ }^{6}$ mainly reflecting the deteriorating quality of CESEE assets, where the NPL ratio reached almost 16 percent. In addition, obtaining a clear picture of Austrian banks' CESEE asset quality remains difficult, including because of different reporting practices across countries in the region (Box 2). In this regard, the bank asset quality reviews by the ECB, expected to be concluded next year, should provide further valuable information on Austrian banks' balance sheets.

\footnotetext{
${ }^{6}$ The NPL data in Table 5 (around 2.8 percent) refer to domestic NPL data before netting out interbank loans.
} 


\section{Box 2. Asset Quality of Austrian Banks in CESEE Countries}

Asset quality is deteriorating in many CESEE countries, in some cases sharply. NPLs have more than doubled in Romania over the past three years and are rising sharply in other countries where Austrian banks have large exposures (Figure 4). While this is partly due to deteriorating macroeconomic fundamentals, lax lending standards before the crisis also played a role. For instance, FCLs were often extended to households that did not have matching FC income, and suffered from the depreciation of CESEE currencies. Since 2008, Austrian banks have cut back FCLs in several countries (Figure 6).

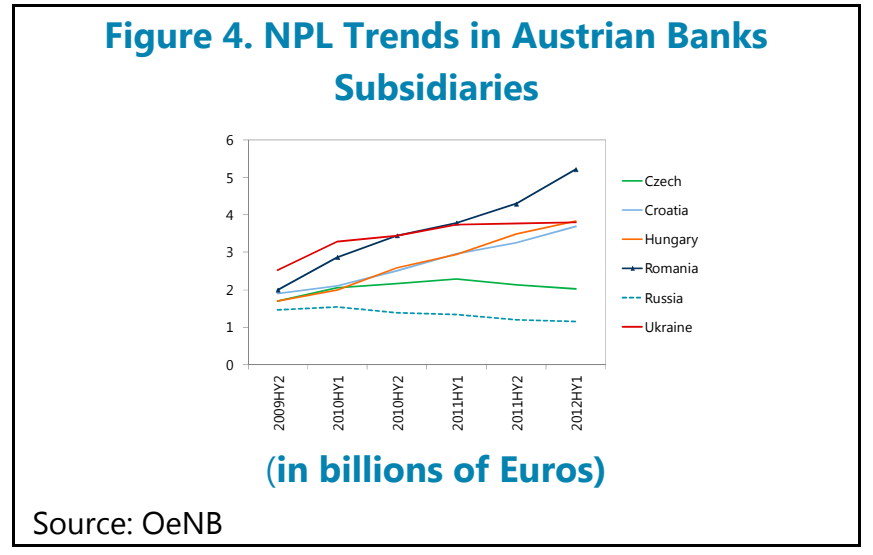

Loan provisioning may be inadequate in some countries. ${ }^{7}$ Loan loss provisions (LLP) are near 50 percent or below in some countries, such as Czech, Romania, Hungary, Croatia and Slovenia (Figure 5). In countries with LLP above 60 percent (e.g., Russia and Slovakia), asset quality evaluation needs to take into account the degree of loan collateralization; for example, loans in Russia are mainly on an unsecured basis, so that LLP of nearly 80 percent still involve high risks.

Obtaining a consolidated view of asset quality in Austrian banks is difficult because of differences in local accounting standards and recovery

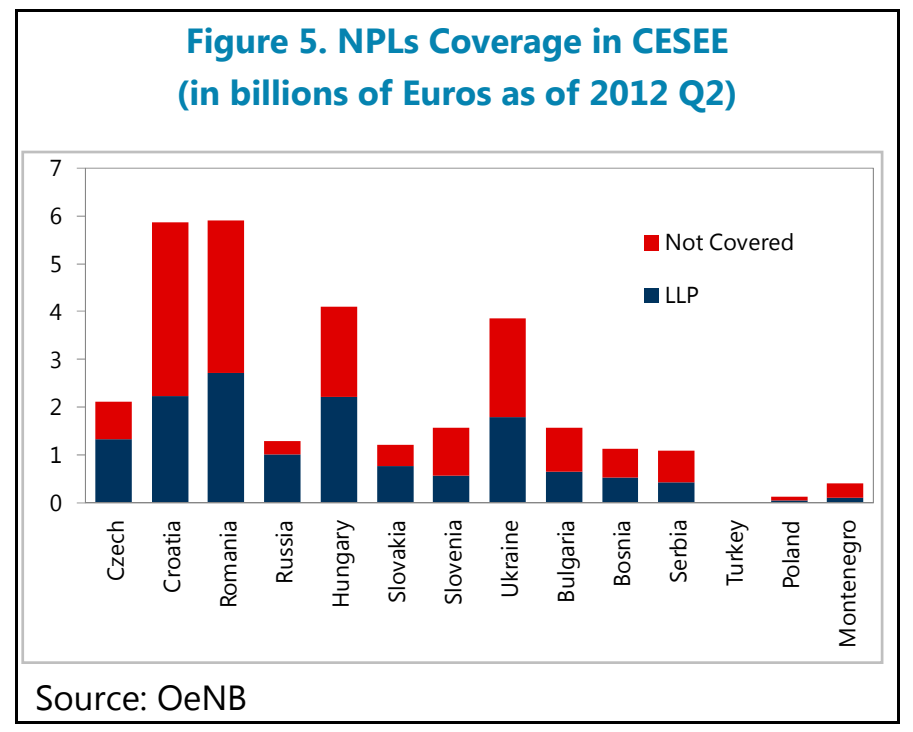

rates. Most CESEE countries define NPLs as loans that are overdue for more than 90 days. However, there are differences in the recording of loans unlikely to receive scheduled payments prior to 90 days; as to whether a debtor's default is recognized across all obligations when loan is impaired; and in the way restructured loans are reclassified. ${ }^{8}$

\footnotetext{
${ }^{7}$ Figures for NPLs and corresponding provisions are for lending from local subsidiaries as well as on a cross-border basis.

${ }^{8}$ See "Working Group on NPLs in Central, Eastern and Southeastern Europe, European Banking Coordination," Vienna Initiative, March 2012. (www.imf.org/external/region/eur/pdf/2012/030112.pdf).
} 


\section{Foreign-currency loan (FCL) exposures are declining both domestically and in CESEE.}

Almost half of the loans extended by Austrian bank subsidiaries in the CESEE region are in foreign currency, of which about 60 percent are denominated in EUR, and the remainder in CHF or USD (Figure 6). ${ }^{9,} 10$ Most FCLs to domestic households are mortgages to be repaid as a lump sum at maturity ("bullet loans") and for this, regular loan installments are directed to repayment vehicles (RPVs) invested in capital market instruments. Borrowers are thus exposed to both exchange rate and asset price risks. Funding gaps could arise as a result. However, sensitivity analyses suggest that the RVP-related risks remain manageable (Appendix IV).

\section{Austrian banks' overall}

\section{funding structure remains} comparatively strong, but foreign currency funding needs create risks

(Figure 7). Deposits represent nearly half of all funding sources, and bonds and interbank liabilities about 20 percent each. ${ }^{11}$ Deposit growth has been strong in both Austria and CESEE, and Austrian banks have not had difficulties in tapping capital markets. Loan-to-deposit ratios have declined from 140 percent to about 120 percent at present. However,

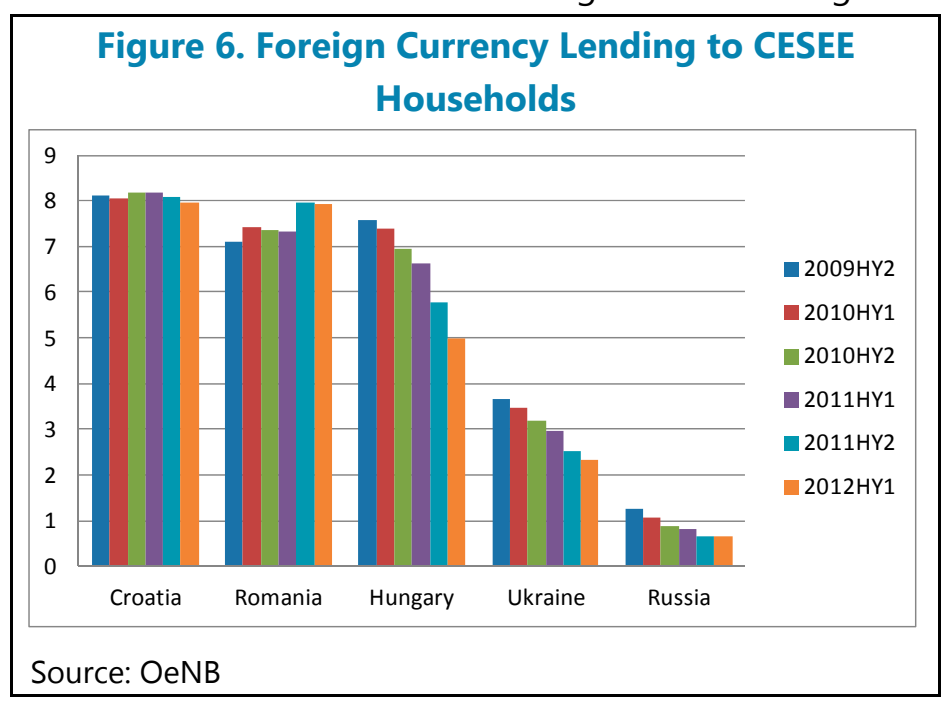
Austrian banks have to rely on wholesale markets to fund large foreign-currency asset portfolios. Such funding is based largely on FX swap markets and could be affected by disruptions in these

\footnotetext{
${ }^{9}$ Unmatched positions in foreign currency originate mostly from foreign currency lending in CHF, both in Austria and the CESEE. On the other hand, foreign currency mismatches from FCL in EUR and USD in the CESEE and CIS regions are less prominent given widespread euroization (CESEE) and dollarization (CIS) in these countries.

${ }^{10}$ In March 2010, the authorities issued new minimum standards providing that FCLs in Austria may be extended only to households and SMEs with the highest creditworthiness or having a natural hedge. Banks were also called on to develop strategies for a sustained reduction in the volume of FCLs and actively support consumers wishing to reduce their foreign currency risk. In spring 2010, restrictions on new FCLs (except EUR) to un-hedged households and SMEs were imposed on Austrian bank subsidiaries in the CESEE. Consumer loans in EUR can only be provided to the highest creditworthiness customers and EUR mortgages extended only in consultation with host country regulators.

${ }^{11}$ Interbank liabilities are mainly comprised of intra-group transactions, especially among cooperative and savings institutions.
} 
markets, although the measures introduced in October 2008 to support enhanced management of foreign currency funding risks have increased banks' resilience to liquidity shocks in USD and CHF.

\section{Bank profitability has recently declined due to falling net interest margins and higher}

risk provisioning. In comparison with their

international peers, Austrian banks are above average on both consolidated return on assets and net interest margin (despite a competitive business environment domestically). Large operations in CESEE countries continue to support the overall profitability of the Austrian banking system (Figure 8). In 2012, however, net income declined in part due to higher provisioning needs against rising NPLS in CESEE countries.

\section{Banks' regulatory capital ratios are improving but remain slightly below average in peer country and bank group comparisons}

Figure 8. Breakdown of Operating Income (consolidated basis)

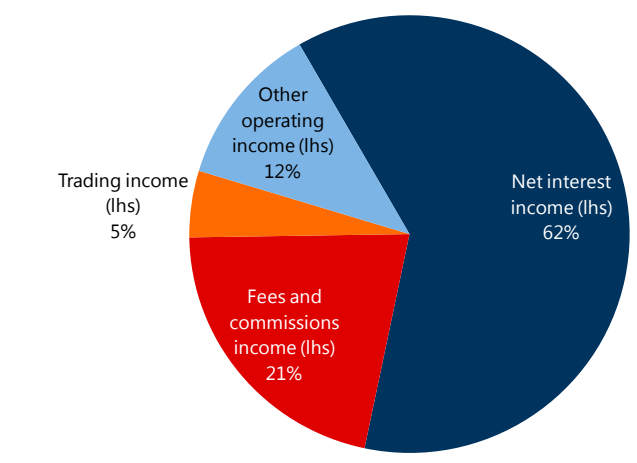

Source: OeNB

(Figure 9). Austrian banks increased their core capital ratios since the crisis through a combination of state capital injections, retained earnings, liability management, and high risk asset disposals. While they are below average in a peer comparison of Tier 1 ratios, they compare more favorably on leverage ratios, reflecting their traditional business focus on retail banking. Capital quality remains an issue however, as Austrian banks' CET1 capital includes a relatively high share of participation capital ( $€ 5.2$ billion, i.e., about 7 percent on aggregate, but concentrated among the largest banks), of which government participations amount to $€ 4.1$ billion.

Figure 9. Capitalization Ratios-Peer Banks

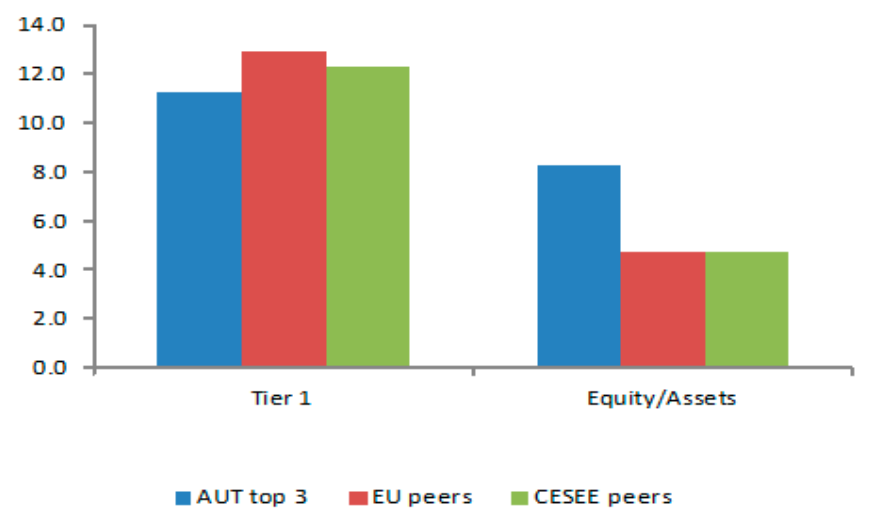

Source: Bankscope and IMF staff calculations

EU peers include 38 largest banks from the 2011 EBA list.

CESEE peers include the 12 foreign banks with largest exposures in the CESEE. 
14. Most insurance companies appear well-capitalized under the current Solvency I regime, but face significant challenges (Table 6). Solvency is not a concern at this point and overall premium revenues remain stable. Most insurance companies appear well-capitalized with solvency ratios near 200 percent as of end-2011 (latest available data point). Life insurers were at about 180 percent; and non-life close to 590 percent. For the industry as a whole, declining premiums on the life insurance sector were mostly covered by rising premiums on non-life business. Key challenges are two-fold:

- Low interest rate environment. Life insurance companies have legacy liabilities guaranteeing rates well above current yields on government bonds which, given their asset/liability duration mismatches, affects their profitability. ${ }^{12}$ Internationally-active insurance companies with diversified product lines have been better insulated from the combined impact of a low interest rate and low growth environment, as they have benefited from rapid growth in premium income in the CESEE region.

- Banking sector exposures. The banking sector's exposure to the insurance industry is small (only 0.2 percent of unconsolidated assets), but the insurance industry holds roughly $€ 20$ billion (about 20 percent of its assets) in capital instruments of European banks, of which 96 percent are bank bonds and the remaining 4 percent bank equity. ${ }^{13}$

\section{B. Stress Tests}

\section{A broad range of stress tests were conducted, covering the entire Austrian banking} system (Figure 10 and Appendix III). The OeNB solvency stress testing platform, which covers all banks in the system, enabled top-down tests that took into account a granular assessment of credit risk exposures in partner countries. These tests were complemented by sensitivity analyses covering in particular indirect credit risk from FCLs, and with bottom-up tests conducted by the top five banks (representing about 60 percent of total bank assets), focusing on market and sovereign risk. Additional stress tests were conducted to assess liquidity and contagion risks, and a combined market and balance sheet-based approach was used to assess potential contagion risks across global banks under extreme distress conditions. ${ }^{14}$

\section{Three adverse scenarios were considered for the top-down solvency stress tests:}

- A global shock and intensification of the euro area economic crisis, generating a two-standard deviation shock to Austrian GDP growth, and spillover effects to the CESEE/CIS region;

\footnotetext{
${ }^{12}$ Life insurance products guarantee a minimum rate of return set by the FMA annually, which corresponds to the average yield on 10-year government bonds.

${ }^{13}$ In addition, some banks provide guarantees on insurance products, which could be in question should banks undergo financial distress. The FMA estimates that technical provisions for products with external guarantors were slightly more than $€ 6$ billion at end-2011.

${ }^{14}$ Using the CoVaR methodology.
} 
- $\quad$ A severe recession in CESEE/CIS, adding aggravated downturns in that region to the previous scenario, ${ }^{15}$

- A global funding scenario reflecting the acute stress conditions observed in late 2008, when Austrian banks faced increased funding costs and restricted access to FX swap markets.

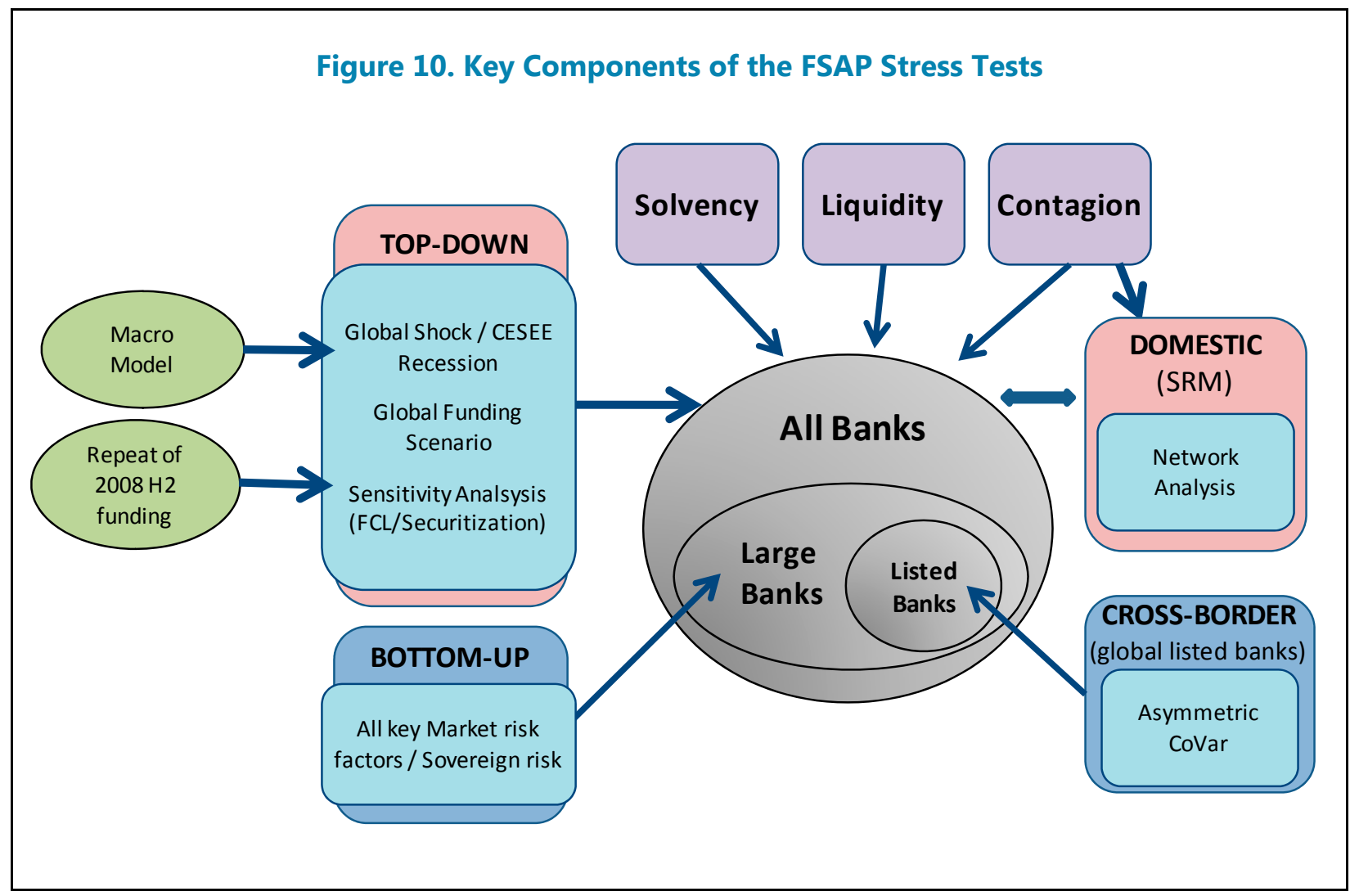

17. For the system as a whole, the analysis suggests that Austrian banks benefit from sufficient capital buffers to meet regulatory requirements by 2015 , including under adverse circumstances (Figures 19-20), although these results need to be interpreted with caution given the existing limitations on asset quality data noted above. Specifically:

- Under the most severe macroeconomic scenario, banks representing less than 7 percent of total bank assets would fall below the current regulatory threshold, and the estimated aggregate capital shortfall would be about $€ 3.4$ billion ( 0.3 percent of total bank assets, or

\footnotetext{
${ }^{15}$ Deviations from baseline growth forecasts for countries to which Austrian banks are most exposed (Croatia, Czech Republic, Poland, Slovak Republic) or with persistent economic imbalances (Hungary, Romania, Ukraine) reached about 2 standard deviations.
} 
one percent of GDP). ${ }^{16}$ Key pockets of vulnerability are thus among smaller Austrian banks, some of which combine low initial capital buffers and weak profitability prospects. ${ }^{17}$

- Separately, sensitivity analyses show a potential for additional credit risk losses from $\mathrm{FCL}$ exposures in Austria and CESEE (from exchange rate appreciation) of up to 35 bps of aggregate capital ratios.

- $\quad$ Full Basel III implementation (including front-loading phase-in capital arrangements and Basel III RWAs) would have an additional impact of 1.4 percentage points of EBA CT1 capital.

- Under the combination of severe macroeconomic stress and assumptions separately used for sensitivity analyses, the capital adequacy ratio of the system would stand at 12.0 percent at end-2015, well above the regulatory capital hurdle rate of 8 percent.

Figure 11. Drivers of Changes in CT1 for the Whole Banking

System

(in percentage points of regulatory capital)

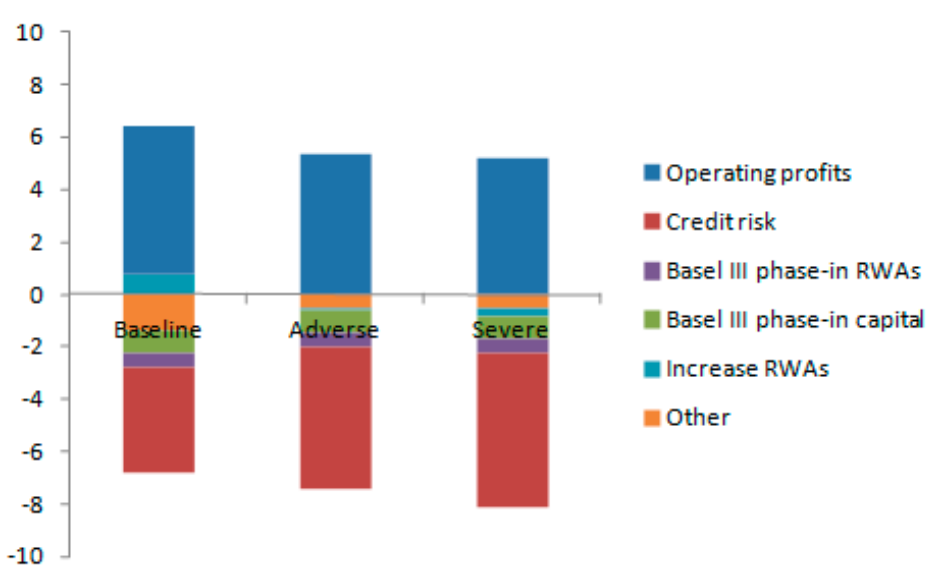

Source: National Bank of Austria and IMF staff calculations

18. More specifically, the large internationally-active Austrian banks remain on aggregate above regulatory hurdles under Basel III implementation by 2015 . Baseline projections of estimated CET1 for this group remain above 7 percent throughout the whole horizon, even netting out the private and state participation capital subscribed under the bank support package. Building in the Basel III implementation of qualitative phase-in arrangements by 2015 for CET1, Tier I, and

\footnotetext{
${ }^{16}$ The stress tests are forward looking and estimate the capital shortfall of the banking system under adverse macroeconomic developments over 2013-2015. They do not capture all unrecognized losses from past developments.

${ }^{17}$ Some small local banks would even fail under the baseline scenario.
} 
Total Capital, large international banks' projected capital ratios are on aggregate above the transitional quantitative hurdle rates even under the most severe scenario.

19. Market, liquidity and contagion risks also appear manageable, although some banks should strengthen further their CHF funding structure. Credit risk from FCL appears to have greater solvency impact than sovereign and market risks combined. The additional credit risk from $\mathrm{FCL}$ would reduce $\mathrm{CT} 1$ capital ratios for the five top banks by 41 bps under the most adverse scenario (Figure 20). ${ }^{18}$ Under a scenario assuming the closure for one year of unsecured interbank and FX-swap markets, and with substantial haircuts in the counterbalancing capacity, the total liquidity shortfall amounts to only 0.5 percent of total liabilities of the 29 banks in the sample. For CHF liquidity, however, about half of Austrian banks need to make further progress to diversify funding sources across counterparties and instruments, and lengthen funding tenors. Finally, according to market-based analyses, the risk that severe distress of the top two Austrian banks may affect other banks in CESEE is not negligible, but less than that potentially introduced by distress of other CESEE peer banks (Figure 21). Inward cross-border spillovers would be most significant from distress of foreign banks that have the highest presence in the region.

\section{Summary Assessment}

20. Austria's large banks seem well positioned to meet Basel III requirements over the medium-term, but will need to replace government participation capital. The impact of Basel III implementation will be mitigated by Austrian banks' very limited capital market activities and exposures (which carry much higher risk weights under Basel III), and by the length of the transitional period. However, banks also face the challenge of repaying recent public capital support. Indeed, government participations must be phased-out between 2014 and 2022, and it is expected that most will be repaid between 2015 and 2017. ${ }^{19}$ The authorities estimate that to comply with Basel III regulatory capital ratios while repaying public capital, Austrian banks may need to raise additional CET1 capital of $€ 1$ billion and up to $€ 7$ billion additional Tier I and Tier II capital by $2022 .{ }^{20}$

\section{Therefore, the risk that Austrian banks may become subject to strong deleveraging} pressures, with potential spillovers to host CESEE countries, appears contained at this point. The need for some banks to repay public support, reduce loans to local stable funding ratios for their subsidiaries, or address asset quality concerns in individual CESEE countries, may lead to

\footnotetext{
${ }^{18}$ In particular, losses from adverse shocks on a range of other market risk factors including interest rates, FX, equity prices, commodities, high yield credit risk, and CVA are insignificant.

${ }^{19}$ Dividend step-ups on government capital are due in 2015 (50 bps). In addition, under Basel III transitional arrangements, grandfathering provisions on public participation capital provided in 2008-09 will expire in 2017thereafter, these participations will no longer qualify as non-core Tier I or Tier II capital.

${ }^{20}$ This amount consists of $€ 1$ billion for additional CET1, $€ 2$ billion for additional Tier I capital, and $€ 5$ billion for the replacement of Tier II capital.
} 
cutbacks in certain CESEE operations. ${ }^{21}$ However, sales of CESEE operations will not necessarily result in reduced credit supply from the new owners. In any case, a broad-based reduction in the overall presence of Austrian banks in the region seems unlikely based on the existing strategy of internationally-active Austrian banks and the importance of CESEE operations to their overall profitability.

\section{Still, Austrian banks will need to build stronger capital buffers above the regulatory} minimum going forward. Additional capital requirements may be imposed on Austrian banks by investors in order to ensure that they keep pace with their peers, and as a result of their specific business model and comparatively large exposures to the CESEE region, where underlying asset quality is subject to significant uncertainty. In this regard, the upcoming bank asset quality reviews by the ECB should provide a more robust basis for assessing the strength of the balance sheets of Austrian banks and the policy responses that may be needed. These concerns may also be exacerbated by an increase in financial market fragmentation across the region, including through the potential introduction of capital or liquidity ring-fencing measures in host countries, which would constrain funding relationships between local subsidiaries and parent Austrian banks, as well as profit repatriation.

\section{While the risk of adverse feedback loops between Austria's banks and sovereign appears limited, sovereign risk perceptions have deteriorated during the crisis (Figure 12).}

Austrian banks have little direct exposure to the public sector (about 2 percent of banking system assets). Nevertheless, a potential downgrade of the sovereign would likely raise market funding costs for Austrian banks. Since the beginning of the crisis, market perceptions of Austria's creditworthiness have become more closely linked to the health of its banking system. For instance, since 2011, the Austrian sovereign has recently shown a higher correlation in CDS spreads with the top two Austrian banks.

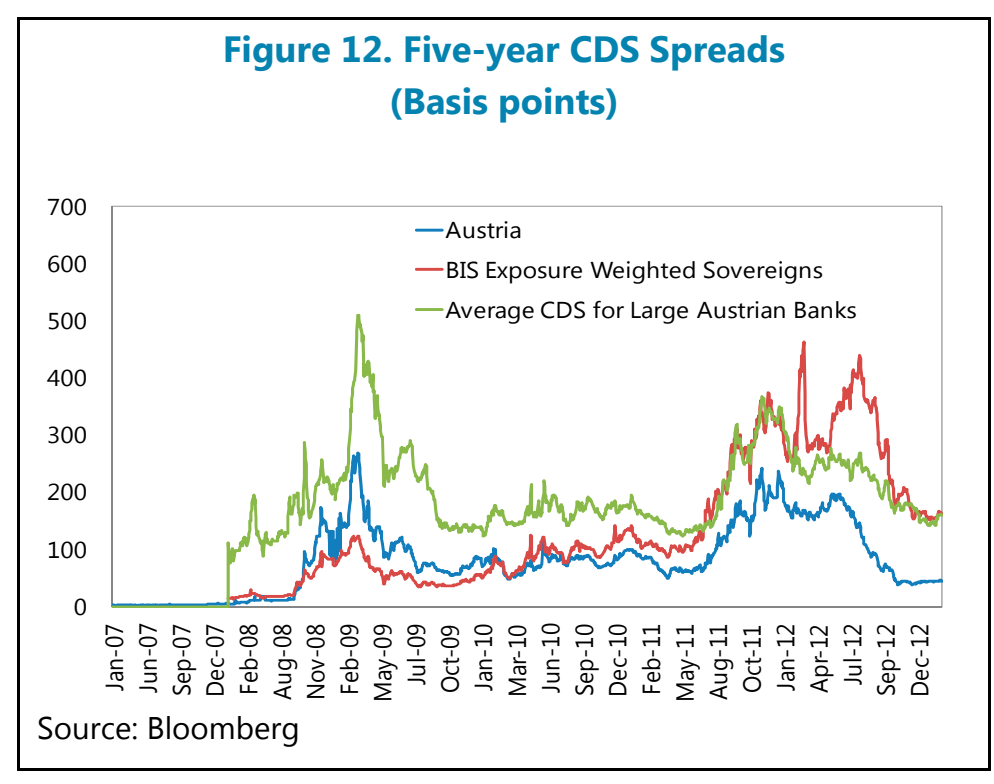

\section{Over the longer term, there are some significant structural challenges in parts of} Austria's banking system, especially smaller banks. Notwithstanding a long-term consolidation

\footnotetext{
${ }^{21}$ Banks indicate that the decision to cut back exposure in a particular country would be based on a number of factors, including market share, local policy considerations and business climate, and not just on immediate concerns about local profitability.
} 
trend in the system, ${ }^{22}$ the domestic market remains crowded with small banks and characterized by a low profitability environment. The large number of small-size banking units implies higher operational costs associated with lower economies of scale and higher bank employee density (Figure 13). Domestically-focused retail banks will also likely face increasing competition and cost pressures in this environment going forward, including due to the increasing penetration of lower cost non-traditional retail banking vehicles, such as mobile branches, co-branching and internet banking.

Figure 13. Select Euro Area Countries: Bank Branches and Employees per 10000 Inhabitants

Selected Euro Area Countries: Bank Branches per 10000 Inhabitants, 2012 1/

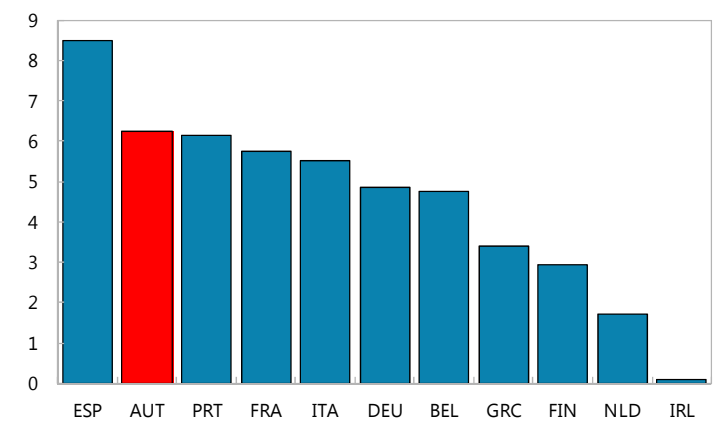

1/ Population data for 2010
Selected Euro Area Countries: Number of Bank Employees per 10000 Inhabitants, 2011 1/

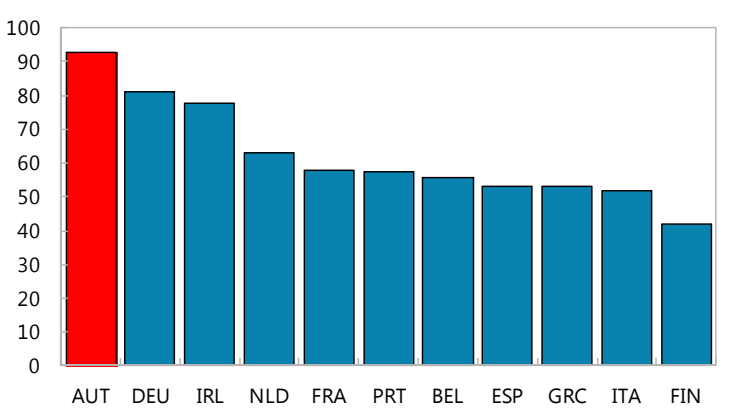

Sources: ECB; World Bank; and IMF staff calculations.

\section{FINANCIAL OVERSIGHT}

25. Financial stability is a shared responsibility of the FMA, OeNB, and MOF. Austria has a dual supervisory system involving the FMA and OeNB, while the Ministry of Finance is responsible for developing financial sector legislations. The FMA, as the integrated supervisory agency, is responsible for supervising all significant providers of financial services (including insurance companies and pension funds, investment funds, and the stock exchange). The OeNB collaborates with the FMA in implementing bank supervision, and is responsible for the oversight of payment systems.

\footnotetext{
${ }^{22}$ For example the number of small rural member cooperatives that belong to the Raiffeisen group has declined from 1,300 in 1979 to 520 at end-2012.
} 


\section{A. Banking Oversight}

26. Overall, bank supervision performed by the FMA and OeNB appears effective. ${ }^{23} \mathrm{Clear}$ responsibilities, objectives and powers are attributed to the FMA as the financial sector supervisor in Austria. A key element of the cooperation between the FMA and the OeNB is the sharing of all supervisory-related data held by both institutions in a single database. In general, the existing supervisory approach, techniques and tools, and reporting systems are adequate.

27. Governance improvements are needed both within the FMA and in the industry. The current liability framework does not sufficiently protect the FMA and its staff, and the FMA's independence could be further strengthened. ${ }^{24}$ As regards the industry, the FMA should have the power to undertake fit and proper tests on all members of bank supervisory boards, including for smaller banks, ${ }^{25}$ and to require changes in the composition of supervisory boards if their members do not fulfill their duties. In keeping with best international practice, it would also be more appropriate for internal auditors to report directly to supervisory committee chairmen, rather than first to the board of directors. Finally, all banks should be explicitly required to have a compliance function, and for the larger and more complex banks, to have a dedicated risk management unit overseen by a chief risk officer or equivalent function.

28. While the current legal and regulatory framework generally supports adequate crossborder supervisory cooperation, legal constraints hamper effective information exchange with some countries. Many Austrian banks operate across borders, and an adequate framework for cooperation with other authorities is implemented, including an adequate protection of confidential information. In particular, for the largest cross-border operating banking groups, fully-fledged colleges are in place, and Austria has played a leading role in this respect. However, it has not been possible to conclude agreements on the exchange of confidential supervisory information with some non-EEA host supervisors, which limits effective supervisory cooperation for the banking groups concerned. ${ }^{26}$

29. The supervisory tools and powers available to the FMA should be further enhanced:

- $\quad$ Prior approval. This process needs to be extended to apply in particular to investments by Austrian banks in non-bank financial institutions outside the EEA or for setting up a credit institution in a third country by means of a greenfield operation.

\footnotetext{
${ }^{23}$ See the April 2013 assessment of Austria's compliance with the Basel Core Principles.

${ }^{24}$ For instance, through an obligation to publicly disclose the reason for dismissing an FMA Executive Board member, and by better disconnecting the terms of FMA Supervisory Board members from the political cycle.

${ }^{25}$ At present, the FMA has such powers only for directors and (for large banks) on chairmen of supervisory boards.

${ }^{26}$ In case of inadequate information exchange, the FMA has authority to order the dissolution of that part of the banking group which is affected by this constraint.
} 
- $\quad$ Recovery and resolution plans. The obligation to draw up such plans currently only exists for the three largest banking groups and may need to be extended to other large banks. Corrective actions. Such actions rely heavily on extra capital requirements and on penalties at present, but the FMA also needs the powers to directly prohibit, limit, or set other conditions on specific business activities or exposures.

- $\quad$ Related party lending. Even though there is no evidence that this is a material issue in Austria, relevant supervisory rules need to be strengthened (e.g., to require that transactions with related parties must not be on favorable terms).

- Rule-making authority. The FMA has only limited authority to issue legally-binding rules.

30. The authorities should continue to actively prepare for the implementation of the SSM. The top eight Austrian banking groups are expected to fall under direct ECB supervision. Although the full modalities of the SSM still need to be finalized, the authorities should further prepare for its implementation, including by taking specific measures to mitigate operational risks from the division of responsibilities between the ECB, the FMA and the OeNB, especially during the transition; enhance cooperation with the ECB for ongoing supervision (especially on-site); and ensure effective coordination with the ECB in validating recovery and resolution plans for SIFIs.

\section{B. Insurance Oversight}

31. Based on international standards, the Austrian regulatory and supervisory regime for insurers and pension funds continues to perform well. ${ }^{27}$ Indeed, the FMA has taken stepsthrough local, regional, EU-wide, and international initiatives-to strengthen insurance and pension regulation and supervision to meet the challenges identified in previous FSAP assessments.

\section{Many of the needed reforms are expected to be dealt with under Solvency II, but the} authorities may need to take swifter action. The FMA should continue to prepare itself, and to ensure that the industry is prepared, to effectively implement Solvency II. Also, while the timing and content of Solvency II remain unsettled, the FMA should nevertheless continue to further improve the level of observance of the ICPs. In particular:

- Prudential requirements should be strengthened, including by revising the liability valuation approach to take fuller account of experience and require consistent provisioning for guarantees; issuing a minimum standard on enterprise risk management; and considering a wider range of risks than Solvency I in assessing capital adequacy.

- Supervisory assessments should be enhanced through improved and harmonized risk-rating methodologies; a more structured internal review of risk assessments; and an increased use of

\footnotetext{
27 This assessment, conducted in February 2013, is based on the IAIS Insurance Core Principles, as adopted in October 2011 and amended in October 2012.
} 
risk ratings in supervisory planning. On-site inspections should be more frequent, depending on risk profiles, and standard stress tests should widen the range of risks tested, including more refined scenarios and based on internal models.

- Supervisory collaboration should be increased through ongoing involvement in macroprudential policy decisions. Cross-border cooperation should also be enhanced through additional MoUs to facilitate the participation of insurance supervisors from all jurisdictions in which Austrian insurers operate in relevant supervisory colleges.

\section{In the industry, governance should be strengthened by enhancing the role of control}

functions. Legislation should be revised to extend suitability requirements to key persons in control functions, to require insurers to establish a compliance function, to require non-life insurers to establish an actuarial function and to appoint a responsible actuary, and to require either that the responsible actuary and the head of internal audit report directly to the supervisory board or guarantee their access to it. Requirements for public disclosure by insurers should also be strengthened.

\section{Macroprudential Perspective}

34. The authorities are about to implement the ESRB recommendation on national macroprudential mandates and to introduce a formal macroprudential framework. Under a recent legislative proposal, it is now envisaged that a joint committee would be created, and would issue recommendations to the FMA under the 'comply or explain' principle. The committee would be chaired by the MOF, and new policy macroprudential instruments would be introduced consistent with the CRD IV directive.

35. The framework envisaged by the authorities could be improved in some respects. Building on the comparative advantages of the FMA ('prudential supervision') and the OeNB ('systemic risk monitoring'), the new joint committee should be designated as the macroprudential regulator formulating macroprudential policies and setting related rules-either on its own initiative, or to implement ESRB or ECB decisions-and be chaired by the OeNB, in line with the ESRB Recommendation to give a leading role to central banks. In addition, and while the envisaged CRR/CRD macroprudential tools are a welcome expansion of existing prudential measures, more tools could usefully be considered, such as structural measures, and LTV and DTI ratios. Finally, the mandate of the FMA will need to be revised to clarify that the FMA will enforce macroprudential rules in addition to continuing to be the microprudential supervisor.

\section{Anti-money Laundering and Combating the Financing of Terrorism} (AML/CFT)

36. Austria's AML/CFT framework is relatively strong, but areas for improvement have been highlighted. Austria's AML/CFT framework was last assessed in 2008 and is scheduled for 
reassessment in the first half of $2015 .^{28}$ Assessors noted in 2008 that the framework was comprehensive and supported by well-developed law enforcement and supervisory bodies. Some shortcomings were identified, in particular with respect to preventive measures (including customer due diligence and suspicious transaction reporting requirements), confidentiality provisions, the financial intelligence unit, and transparency of legal entities. The authorities reported to the Financial Action Task Force (FATF) that they took a number of steps since 2008, such as facilitating their access to confidential information, strengthening customer due diligence and reporting requirements, and increasing the transparency of legal entities. The authorities are encouraged to address the remaining deficiencies, notably with respect to the criminalization of terrorist financing.

\section{CRISIS PREVENTION}

\section{A. Early Intervention and Liquidity Support}

\section{The authorities have proposed to introduce a more comprehensive legal framework} for early intervention, but additional changes may be warranted. Currently, the FMA has some corrective powers at its disposal under its supervisory enforcement framework. ${ }^{29}$ Building on this, the proposal introduces more specific intervention triggers and tools. ${ }^{30}$ However, the tools available to the FMA could be further expanded and better linked to specific (and graduated) triggers. Such powers should also allow the FMA to require an increase in bank loss absorbency (e.g., capital increases, or the issuance of convertible bonds or bail-inable unsecured long-term debt); appoint a special administrator; replace management; and restrict dividend payments. The law should also provide for measures related to banking groups, such as regarding ring-fencing institutions from parent bank decisions or related entities.

38. The OeNB's current ELA framework could be strengthened. In 2006, the OeNB revised its ELA policy framework, and it intends to update it again only once new Eurosystem-wide ELA arrangements for NCBs are introduced. Indeed, the crisis has triggered important changes in the Eurosystem and a move toward more 'rule-based transparency' is underway, aiming to better

\footnotetext{
${ }^{28}$ FSAPs updates should incorporate a full AML/CFT assessment undertaken approximately every five years, and to the extent possible within 18 months before or after the FSAP mission. The planned assessment is beyond this timeframe, but this was seen as acceptable for this FSAP in light of current circumstances. Indeed, the 2011-2013 revision of the $A M L / C F T$ standard and relevant assessment methodology resulted in a suspension of most $A M L / C F T$ assessments and a backlog of countries subject to reassessment for FSAP purposes.

${ }^{29}$ The FMA can appoint a government commissioner, prohibit capital withdrawals, restrict distribution of capital and earnings, or discontinue the institution's operations. For breach of licensing or other legal requirements, it can impose penalties and compliance, remove Directors, and/or revoke a license. In some circumstances, it can require additional capital, restrict the payment of interest and dividends, and order the conversion of hybrid capital.

${ }^{30}$ Triggers would include non-compliance with capital and liquidity requirements or with the requirement to prepare or improve a recovery or resolution plan. Early intervention measures would include the implementation of one or more recovery measures from the recovery plan; carrying out specific improvements to risk management practices; convening a General Meeting; and preparing a negotiation plan for a voluntary restructuring of liabilities with creditors.
} 
balance financial stability and central bank's financial autonomy considerations. In Austria, key steps include formalizing new ELA policies that maintain the discretionary nature of ELA and preserve the autonomy of OeNB's decisions, possibly together with a cap on total outstanding ELA to prevent adverse fiscal consequences; requiring that a capital shortfall be covered by the Federation; ${ }^{31}$ and concluding an agreement with the Federation to promptly indemnify the OeNB for ELA-related losses that cannot be covered by the OeNB's reserves.

\section{B. Bank Resolution Framework}

\section{Recent experience with the three nationalized banks confirms the importance for} Austria to be better prepared to resolve banks going forward. Austria does not have a special framework in place to support orderly resolution of troubled banks and the authorities do not intend to introduce such a framework before the adoption of the EU Bank Recovery and Resolution Directive. Cross-country experience suggests that losses at troubled banks are almost always greater than supervisors estimate, and in the absence of adequate resolution framework, may more likely give rise to pressures for open-ended financial support. Currently, the full details and implementation of restructuring plans for the three nationalized Austrian banks remain uncertain, introducing significant risks as to their eventual cost, even though such a cost appears manageable from a fiscal standpoint. Going forward, these risks could be greatly reduced if a special bank resolution framework were in place to deal with distressed banks, for example by revoking a bank license and creating a bridge bank, and limiting liability for losses to creditors and/or shareholders whose claims go against the bankruptcy estate.

40. Within the current framework, some steps can be taken to reduce the cost of resolving the three nationalized banks. While swift action is essential to limit this cost, the authorities also need to follow a flexible approach in order to maximize recoveries and minimize losses. In particular, due diligence should be performed to assess and monitor on a continuous basis the operations and asset quality of troubled banks. Procedures to collect loans and sell assets as soon as possible should be pursued aggressively, as shrinking the balance sheet lessens the need for capital. Finally, entities that are not viable must be wound down in an orderly fashion, coordinated among domestic and foreign public agencies as necessary, including in order to limit potential spillovers to host countries.

\section{A full-fledged bank resolution regime should be introduced based on international} best practices and consistent with the forthcoming EU directive. Such a regime should allow for out-of-court bank resolution by the resolution authority, which should have at its disposal the full range of resolution tools based on leading international practices, including powers to deal efficiently and expeditiously with distressed assets to maintain business value. The mandate of the resolution authority should be clearly cast in terms of promoting financial stability through depositor protection and continuation of systemic financial functions. The FMA should become Austria's bank resolution authority and the legal protection of FMA's bodies and staff should be strengthened in preparation for this role.

\footnotetext{
${ }^{31}$ This would be consistent with the position taken by the ECB in its Convergence Reports.
} 
42. The authorities should also further strengthen cross-border bank resolution arrangements with non-EU/EEA countries. When in force, the EU Directive will cover cross-border bank resolution within the EU and EEA. In light of Austrian banks' very large cross-border exposures, the authorities will need to take initiatives to strengthen the current MoU-based cross-border arrangements for inter-agency cooperation and effective cross-border resolution. This could be done through bilateral or multilateral international agreements (e.g., as part of the CESEE crossborder stability group), providing for adequate information exchanges and burden-sharing mechanisms.

\section{Deposit Insurance Scheme}

43. While the Austrian DGS system has certain advantages, it falls short of best practice, primarily on account of its private, fragmented, and ex post funded nature. Austria has five private guarantee schemes (DGS), organized by sub-sectors and supplemented by a government guarantee introduced in 2008. This complex two-tranche system provides that private schemes cover deposits up to $€ 50,000$ while the government guarantee covers deposits that exceed $€ 50,000$ and up to $€ 100,000$. $^{32}$ Each private scheme is administered by the respective bank association in the sector, funded ex post, and performs valuable oversight and intervention functions that reinforce and complement the FMA's. Repayment of insured depositors (up to $€ 50,000$ ) is accomplished through a three-stage process, which may ultimately involve the provision of public guarantees, while the cost of repaying the second tranche of insured deposits $(€ 50,000-€ 100,000)$ is borne solely by the government. In times of economic distress, extensive public support may thus be required.

\section{The authorities should use the forthcoming EU DGS Directive as an opportunity to} move to a unified and prefunded national DGS. In line with international best practice, banks should bear the cost of bank failures and help safeguard financial stability, and a unified DGS would allow for a higher degree of risk pooling, greater transparency, prompt payout, and more efficient fund management. The national DGS should be aligned with the EU Directive not only in terms of quantities (through minimum coverage limits), but also in terms of prices, with premiums adjusted for risk as far as practicable, and a shortened length of time to payout.

\section{A high-level working group could be formed to organize transition to the new unified} DGS. Such a group could include officials from the MOF, OeNB, FMA, and the various DGSs. It would facilitate the design and implementation of key initial steps, including (i) determining the appropriate target DGS fund size for Austria, taking the target reserve level specified in the forthcoming EU Directive (currently proposed at 1.5 percent of eligible deposits) as a minimum; ${ }^{33}$

\footnotetext{
${ }^{32}$ At the beginning of the 2008 financial crisis the maximum amount of insured deposits per bank and per customer by the private DGS was set at the EU minimum of $€ 20.000$. During the crisis, unlimited coverage of deposits of natural persons was introduced, which expired at end 2009, when the new EU-wide minimum was raised to $€ 100.000$.

${ }^{33}$ Deposit insurance coverage involves two aspects: scope and level. Scope refers to eligible deposits, i.e. which types of deposits qualify for coverage. Level refers to the insured amount (in case of the EU, $€ 100,000$ ). An eligible deposit could be in excess of the insured amount.
} 
(ii) immediately starting to collect premiums on a flat rate basis to begin building an ex ante fund for the new DGS; (iii) and establishing an appropriate liquidity back-up arrangement with the MoF. The single DGS should also be an integral part of a new bank resolution framework, with DGS personnel involved in the advance preparation of bank resolution procedures.

\section{SYSTEMIC CRISIS MANAGEMENT}

\section{In recent years, the authorities have taken several steps to enhance their crisis} preparedness. A crisis team has been established under the FMK, consisting of experts from the MOF, FMA, and OeNB, in line with the MoU of 2008 on co-operation between the financial supervisory authorities, central banks, and finance ministries of the EU. In addition, a Cross-Border Stability Group (CBSG) was established in 2011 to strengthen crisis management with Bulgaria, Czech Republic, Hungary, Slovakia, and Slovenia, and a crisis simulation exercise was conducted with these countries in 2012. ${ }^{34}$ The FMK also organizes regular meetings of the CBSG in order to identify emerging systemic risks. Finally, the FinStaG legal framework was created to provide government financial support, and in November 2008, FIMBAG was established to hold the government financial interests stemming from recapitalization operations.

\section{Additional steps could be considered to further strengthen Austria's crisis}

management arrangements. The government should have the authority to act promptly and under strict conditions, in cooperation with the FMA and OeNB, and with ex post accountability to Parliament, instead of having to go through regular legislative and budgetary procedures prior to taking action. Key additional steps include increasing the financial envelope under the FinStaG, and introducing in the Federal Organic Budget Act an explicit escape clause for financial crises; giving the government standing statutory authorization to take action to deal with financial crises (including financial support and nationalization powers) with ex post accountability to parliament; mandating the CBSG with the preparation of a multilateral binding framework to ensure effective information exchange and cooperation during crises; and creating a cooperation mechanism with non-EU/EEA countries similar to the CBSG. In parallel, FIMBAG's mandate and the conditions under which public capital support is provided should be strengthened. In the short term, FIMBAG should be made responsible for overseeing the implementation of current restructuring plans, and where necessary negotiating changes in these plans. For future recapitalization operations, FIMBAG should be given a more prominent role in negotiating financial contracts and restructuring plans.

\footnotetext{
${ }^{34}$ The participating countries were selected based on the share ( $>5$ percent) of the four largest Austrian banking groups in their markets.
} 


\begin{tabular}{|c|c|c|c|c|c|c|c|c|}
\hline \multicolumn{9}{|c|}{ Table 2. Selected Economic Indicators, 2007-2014 } \\
\hline $\begin{array}{l}\text { Total area } \\
\text { Total population (2012) } \\
\text { GDP per capita (2012 }\end{array}$ & $\begin{array}{l}83,850 \text { squ } \\
8.5 \text { million } \\
\text { US } \$ 46,64\end{array}$ & $\begin{array}{l}\text { e kilom } \\
(36,264\end{array}$ & $\begin{array}{l}\text { ers } \\
\text { ro) }\end{array}$ & & & & & \\
\hline & \multirow[t]{2}{*}{2007} & \multirow[t]{2}{*}{2008} & \multirow[t]{2}{*}{2009} & \multirow[t]{2}{*}{2010} & \multirow[t]{2}{*}{2011} & \multirow[t]{2}{*}{2012} & & 2014 \\
\hline & & & & & & & \multicolumn{2}{|c|}{ Projections } \\
\hline & \multicolumn{8}{|c|}{ (change in percent unless indicated otherwise) } \\
\hline \multicolumn{9}{|l|}{ Demand and supply } \\
\hline GDP & 3.7 & 1.4 & -3.8 & 1.8 & 2.8 & 0.9 & 0.4 & 1.6 \\
\hline Total domestic demand & 2.5 & 0.7 & -2.0 & 1.4 & 3.2 & 0.1 & 0.2 & 1.5 \\
\hline Consumption & 1.2 & 1.6 & 0.9 & 1.5 & 0.7 & 0.4 & 0.5 & 1.1 \\
\hline Gross fixed capital formation & 3.6 & 0.7 & -7.8 & -1.4 & 8.5 & 1.6 & -0.3 & 2.5 \\
\hline Net exports (growth contribution in pp) & 1.4 & 0.8 & -2.2 & 0.6 & -0.1 & 0.9 & 0.2 & 0.2 \\
\hline Exports of goods and nonfactor services & 8.9 & 1.4 & -15.6 & 9.4 & 6.6 & 1.2 & 1.9 & 4.5 \\
\hline Imports of goods and nonfactor services & 7.1 & 0.0 & -13.6 & 9.1 & 7.6 & -0.3 & 1.6 & 4.7 \\
\hline Output gap (percent of potential GDP) & 3.3 & 3.2 & -2.1 & -1.8 & -0.3 & -0.7 & -1.6 & -1.3 \\
\hline Unemployment rate (in percent; Eurostat definition; & 4.4 & 3.8 & 4.8 & 4.4 & 4.2 & 4.3 & 4.9 & 4.8 \\
\hline \multicolumn{9}{|l|}{ Prices } \\
\hline Consumer price index (period average) & 2.2 & 3.2 & 0.4 & 1.7 & 3.6 & 2.6 & 2.1 & 1.8 \\
\hline \multicolumn{9}{|l|}{ General government finances (percent of GDP) } \\
\hline Revenue & 47.6 & 48.3 & 48.5 & 48.3 & 48.3 & 49.1 & 49.1 & 48.7 \\
\hline Expenditure & 48.6 & 49.3 & 52.6 & 52.8 & 50.7 & 51.7 & 51.7 & 51.1 \\
\hline Balance (EDP-definition) & -0.9 & -0.9 & -4.1 & -4.5 & -2.5 & -2.5 & -2.6 & -2.4 \\
\hline Structural Balance 1/ & -2.5 & -2.4 & -3.0 & -3.0 & -2.1 & -1.3 & -1.7 & -1.7 \\
\hline Gross debt (end of period) & 60.2 & 63.8 & 69.2 & 72.3 & 72.8 & 74.1 & 74.3 & 74.7 \\
\hline \multicolumn{9}{|l|}{ Balance of payments } \\
\hline Current account (percent of GDP) & 3.5 & 4.9 & 2.7 & 3.4 & 1.4 & 1.8 & 2.2 & 2.2 \\
\hline \multicolumn{9}{|c|}{$\begin{array}{l}\text { 1/ The structural balance excludes revenue from the } 2012 \text { tax treaty with Switzerland (estimated at } 0.3 \text { percent of } \\
\text { GDP in 2013) and the following capital transfers to banks (in percent of GDP): } 0.6 \text { in 2010; } 0.2 \text { in 2011; } 0.9 \text { in } 2012 \text {; } \\
\text { and budgeted } 0.4 \text { in } 2013 .\end{array}$} \\
\hline Sources: Austrian authorities; and IMF staff estir & mates anc & ojectic & & & & & & \\
\hline
\end{tabular}


Table 3. Vulnerability Indicators, 2007-2012

\begin{tabular}{|c|c|c|c|c|c|c|}
\hline & 2007 & 2008 & 2009 & 2010 & 2011 & 2012 \\
\hline \multicolumn{7}{|l|}{ External Indicators } \\
\hline Exports (real, percentage change) & 8.9 & 1.4 & -15.6 & 8.7 & 7.2 & ... \\
\hline Imports (real, percentage change) & 7.1 & 0.0 & -13.3 & 8.8 & 7.2 & $\ldots$ \\
\hline Current account balance & 3.5 & 4.9 & 2.7 & 3.4 & 0.6 & $\ldots$ \\
\hline Capital and financial account balance & -4.1 & -5.3 & -3.6 & -1.1 & -1.5 & $\ldots$ \\
\hline of which inward foreign direct investment & 16.6 & 1.6 & 2.9 & -7.0 & 3.6 & $\ldots$ \\
\hline of which inward portfolio investment & 13.2 & 6.0 & -1.4 & -0.2 & 2.2 & $\ldots$ \\
\hline of which inward other investment & 4.4 & 3.8 & -9.5 & -1.8 & 4.3 & $\cdots$ \\
\hline \multicolumn{7}{|l|}{ Financial Markets } \\
\hline 3-month interbank rate (percent, eop) & 4.7 & 2.9 & 0.7 & 1.0 & 1.4 & 0.2 \\
\hline 10-year government bond rate (percent, eop) & 4.4 & 3.9 & 3.7 & 3.5 & 2.9 & 1.7 \\
\hline 10-year government bond spread to German Bund (basis points, 1 & 12.5 & 90.4 & 33.0 & 54.4 & 107.5 & 43.2 \\
\hline ATX stock market index (1/1/2007=100, eop) & 101.1 & 39.2 & 55.9 & 65.1 & 42.4 & 53.8 \\
\hline \multicolumn{7}{|l|}{ Real estate price index (real, $2000=100$, eop) } \\
\hline Austria (excl. Vienna) & 98.4 & 97.0 & 97.6 & 101.4 & 102.5 & 109.8 \\
\hline Vienna & 104.0 & 110.6 & 115.3 & 124.1 & 129.0 & 144.5 \\
\hline \multicolumn{7}{|l|}{ Households and non-financial corporates } \\
\hline \multicolumn{7}{|l|}{ Household sector } \\
\hline Household debt & 54.2 & 55.1 & 56.5 & 57.2 & 55.7 & $\ldots$ \\
\hline Household savings (gross) & 16.3 & 16.3 & 16.1 & 14.2 & 12.6 & $\ldots$ \\
\hline \multicolumn{7}{|l|}{ Corporate sector } \\
\hline Corporate debt & 98.1 & 101.9 & 102.3 & 107.6 & 105.5 & $\cdots$ \\
\hline Profit share (gross) ${ }^{1}$ & 43.7 & 42.6 & 40.3 & 41.2 & 41.8 & $\ldots$ \\
\hline Corporate investment (gross) ${ }^{2}$ & 28.6 & 28.5 & 26.8 & 26.7 & 28.4 & \\
\hline \multicolumn{7}{|l|}{ Sources: Austrian authorities; Bloomberg; Haver and IMF staff calculations. } \\
\hline \multicolumn{7}{|l|}{${ }^{1}$ Operating surplus as percent of value added } \\
\hline${ }^{2}$ Investment as percent of value added & & & & & & \\
\hline
\end{tabular}

Table 4. Financial System Structure

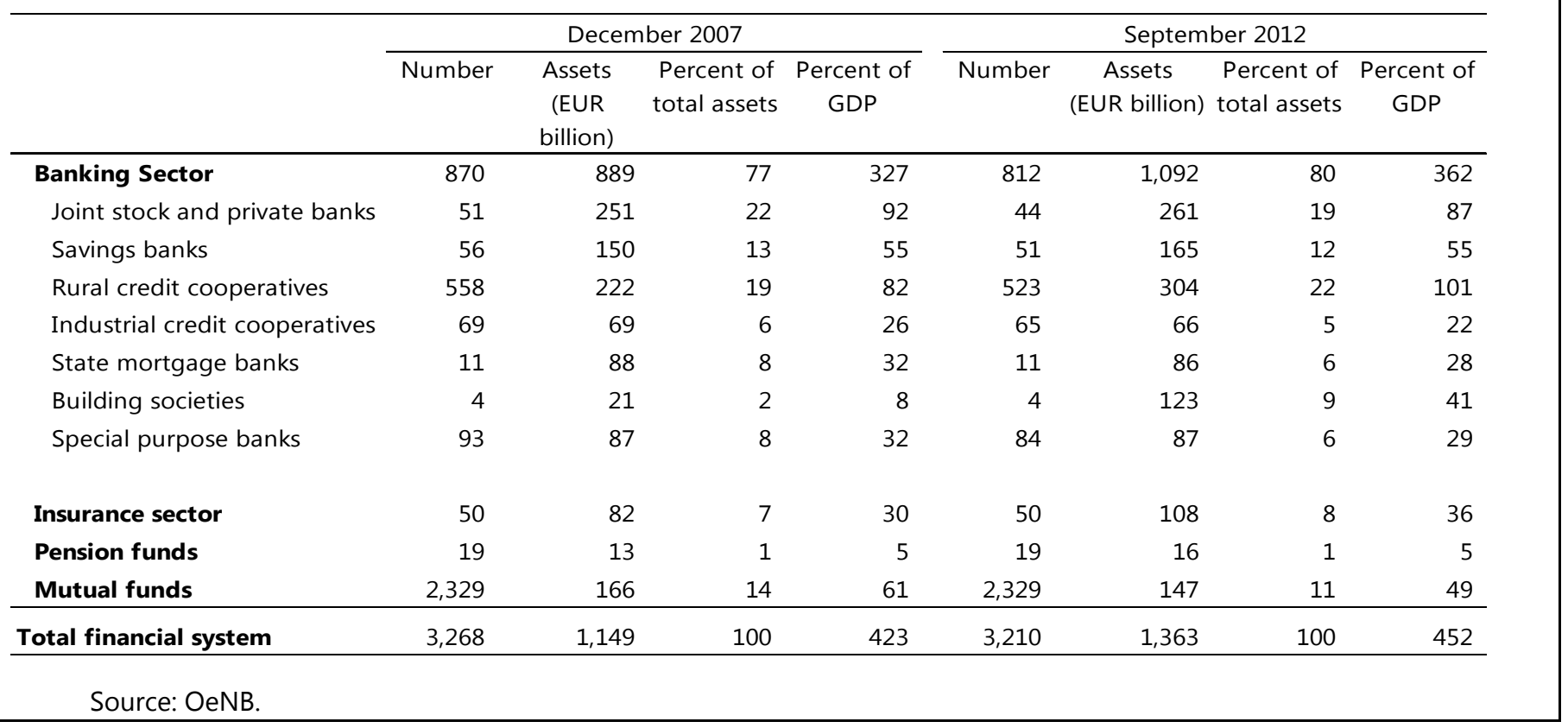




\begin{tabular}{|c|c|c|c|c|c|c|c|c|c|}
\hline \multicolumn{10}{|c|}{$\begin{array}{l}\text { Table 5. Financial Soundness Indicators (FSIs) } \\
\text { (in millions of Euro) }\end{array}$} \\
\hline & $\begin{array}{c}\begin{array}{c}\text { Consolidation } \\
\text { Basis }\end{array} \\
\end{array}$ & 2006 & 2007 & 2008 & 2009 & 2010 & 2011 & 2012Q1 & 2012Q2 \\
\hline Regulatory capital to risk-weighted assets & DCCBS & $13.2 \%$ & $12.7 \%$ & $12.9 \%$ & $15.0 \%$ & $15.4 \%$ & $15.8 \%$ & $16.5 \%$ & $16.5 \%$ \\
\hline Total regulatory capital & & 44,326 & 49,525 & 53,581 & 64,067 & 66,063 & 66,783 & 66,954 & 65,879 \\
\hline Risk-weighted assets & & 335,019 & 390,011 & 415,617 & 426,369 & 427,831 & 421,958 & 405,356 & 400,455 \\
\hline Regulatory Tier 1 capital to risk-weighted assets & DCCBS & $9.0 \%$ & $8.8 \%$ & $9.3 \%$ & $11.1 \%$ & $11.7 \%$ & $12.0 \%$ & $12.7 \%$ & $12.6 \%$ \\
\hline Regulatory Tier 1 capital & & 30,274 & 34,308 & 38,626 & 47,380 & 49,862 & 50,584 & 51,376 & 50,475 \\
\hline Risk-weighted assets & & 335,019 & 390,011 & 415,617 & 426,369 & 427,831 & 421,958 & 405,356 & 400,455 \\
\hline Nonperforming loans net of provisions to capital & DC & $9.5 \%$ & $6.0 \%$ & $8.6 \%$ & $6.3 \%$ & $8.2 \%$ & $8.0 \%$ & $7.8 \%$ & $8.2 \%$ \\
\hline Nonperforming loans net of provisions & & 3,978 & 3,502 & 5,770 & 4,530 & 5,979 & 5,865 & 5,835 & 6,179 \\
\hline Capital & & 41,801 & 58,331 & 67,200 & 72,151 & 73,327 & 72,887 & 74,658 & 75,314 \\
\hline Nonperforming loans to total gross loans $/ 1$ & DC & $2.7 \%$ & $2.2 \%$ & $1.9 \%$ & $2.3 \%$ & $2.8 \%$ & $2.7 \%$ & $2.7 \%$ & $2.8 \%$ \\
\hline Nonperforming loans & & 16,281 & 14,868 & 15,335 & 17,287 & 20,498 & 20,525 & 20,892 & 21,130 \\
\hline Total gross loans & & 594,336 & 663,040 & 805,818 & 768,163 & 724,123 & 758,255 & 766,759 & 767,033 \\
\hline Return on assets (ROA) & DCCBS & $0.7 \%$ & $0.8 \%$ & $0.1 \%$ & $0.1 \%$ & $0.5 \%$ & $0.1 \%$ & $0.2 \%$ & $0.3 \%$ \\
\hline Net income & & 5,099 & 5,835 & 993 & 711 & 3,934 & 697 & 1,880 & 2,502 \\
\hline Total assets & & 712,494 & 747,080 & 831,402 & 879,664 & 857,608 & 875,710 & 884,734 & 873,812 \\
\hline Return on equity (ROE) & DCCBS & $16.8 \%$ & $17.0 \%$ & $2.6 \%$ & $1.5 \%$ & $7.9 \%$ & $1.4 \%$ & $3.7 \%$ & $5.0 \%$ \\
\hline Net income & & 5,099 & 5,835 & 993 & 711 & 3,934 & 697 & 1,880 & 2,502 \\
\hline Capital & & 30,274 & 34,308 & 38,626 & 47,380 & 49,862 & 50,584 & 51,376 & 50,475 \\
\hline Interest margin to gross income & DCCBS & $71.4 \%$ & $70.7 \%$ & $64.6 \%$ & $69.7 \%$ & $67.4 \%$ & $63.3 \%$ & $56.2 \%$ & $56.9 \%$ \\
\hline Interest margin & & 11,311 & 12,540 & 12,977 & 13,749 & 14,624 & 14,651 & 3,523 & 6,777 \\
\hline Gross income & & 15,852 & 17,736 & 20,098 & 19,716 & 21,706 & 23,155 & 6,268 & 11,913 \\
\hline Noninterest expenses to gross income & DCCBS & $68.8 \%$ & $66.6 \%$ & $90.4 \%$ & $86.0 \%$ & $83.0 \%$ & $87.4 \%$ & $71.7 \%$ & $78.4 \%$ \\
\hline Noninterest expenses & & 10,913 & 11,817 & 18,175 & 16,948 & 18,009 & 20,237 & 4,494 & 9,336 \\
\hline Gross income & & 15,852 & 17,736 & 20,098 & 19,716 & 21,706 & 23,155 & 6,268 & 11,913 \\
\hline Liquid assets to total assets & DC & $27.7 \%$ & $26.8 \%$ & $26.8 \%$ & $26.1 \%$ & $23.5 \%$ & $25.4 \%$ & $26.6 \%$ & $26.6 \%$ \\
\hline Liquid assets & & 220,840 & 240,769 & 286,257 & 270,264 & 229,524 & 257,319 & 268,781 & 268,951 \\
\hline Total assets & & 797,758 & 899,542 & $1,069,367$ & $1,034,153$ & 978,638 & $1,014,278$ & $1,011,853$ & $1,011,134$ \\
\hline Liquid assets to short-term liabilities & DC & $68.5 \%$ & $67.1 \%$ & $69.7 \%$ & $76.2 \%$ & $68.0 \%$ & $71.6 \%$ & $76.6 \%$ & $76.3 \%$ \\
\hline Liquid assets & & 220,840 & 240,769 & 286,257 & 270,264 & 229,524 & 257,319 & 268,781 & 268,951 \\
\hline Short-term liabilities & & 322,262 & 358,780 & 410,503 & 354,520 & 337,737 & 359,499 & 350,904 & 352,542 \\
\hline Net open position in foreign exchange to capital & DC & $6.5 \%$ & $2.5 \%$ & $1.6 \%$ & $0.6 \%$ & $0.3 \%$ & $0.1 \%$ & $0.0 \%$ & $0.4 \%$ \\
\hline Net open position in foreign exchange & & 3,906 & 1,971 & 1,432 & 575 & 279 & 105 & 39 & 332 \\
\hline Capital & & 60,428 & 79,933 & 88,559 & 93,248 & 92,162 & 91,367 & 92,417 & 93,029 \\
\hline \multicolumn{10}{|l|}{ Source: National Bank of Austria. } \\
\hline \multicolumn{10}{|c|}{${ }^{1 /}$ It excludes loans to credit institutions as well as debt securities } \\
\hline \multicolumn{10}{|l|}{ Notes: } \\
\hline \multirow{3}{*}{\multicolumn{10}{|c|}{$\begin{array}{l}\text { DCCBS: Domestically controlled, cors-border, cross-sector consolidation basis. This basis covers the data of domestically } \\
\text { incorporated, domestically controlled entities in the sector, their branches (domestic and foreign), and all their subsidiaries } \\
\text { (domestic and foreign) that are classified in the same sector as well as in other sectors. }\end{array}$}} \\
\hline & & & & & & & & & \\
\hline & & & & & & & & & \\
\hline \multicolumn{10}{|c|}{$\begin{array}{l}\text { DC: Domestic consolidation basis including domestic and cross-border operations. This includes the data of resident entities along } \\
\text { with those of their branches and subsidiaries in the same sector that are resident in the domestic economy. }\end{array}$} \\
\hline
\end{tabular}




\begin{tabular}{|c|c|c|c|c|c|c|}
\hline \multicolumn{7}{|c|}{$\begin{array}{l}\text { Table 6. Soundness Indicators for the Insurance Sector } \\
\text { (in percent) }\end{array}$} \\
\hline & 2006 & 2007 & 2008 & 2009 & 2010 & 2011 \\
\hline \multicolumn{7}{|l|}{ Life insurance } \\
\hline Total premimums (euro millions) & 7,136 & 7,157 & 7,317 & 7,356 & 7,467 & 6,928 \\
\hline Pre-tax earnings/net premium & 4.7 & 3.4 & -1.7 & 2.3 & 4.2 & 3.0 \\
\hline Loss ratio & 105.9 & 103.4 & 79.6 & 117.3 & 115.9 & 96.6 \\
\hline Expense ratio & 15.1 & 14.7 & 14.2 & 13.3 & 14.1 & 15.6 \\
\hline Combined ratio & $\ldots$ & $\ldots$ & $\ldots$ & $\ldots$ & $\ldots$ & $\ldots$ \\
\hline Investment income/investment assets & 4.7 & 4.1 & 2.6 & 3.0 & 3.4 & 2.8 \\
\hline Equity/total assets & 8.4 & 8.1 & 4.3 & 4.8 & 4.2 & 4.1 \\
\hline Equity and related assets/total assets & 11.2 & 10.9 & 9.7 & 9.0 & 8.6 & 7.3 \\
\hline Fixed income securities/math Reserves & 54.5 & 55.9 & 58.6 & 59.3 & 60.9 & 60.3 \\
\hline Equity/math Reserves & 9.2 & 8.9 & 4.8 & 5.2 & 4.6 & 4.4 \\
\hline Alternative investments/math Reserves & 0 & 2.1 & 1.8 & 1.3 & 1.1 & 0.8 \\
\hline Solvency ratio & 160.1 & 163.9 & 206.8 & 211.6 & 210.1 & 178.1 \\
\hline \multicolumn{7}{|l|}{ Health insurance } \\
\hline Total premimums (euro millions) & 1,445 & 1,491 & 1,543 & 1,598 & 1,645 & 1,704 \\
\hline Pre-tax earnings/net premium & 5.0 & 2.7 & 3.9 & 5.3 & 7.3 & 4.9 \\
\hline Loss ratio & 72.1 & 71.5 & 71.0 & 69.7 & 68.5 & 67.6 \\
\hline Expense ratio & 14.4 & 14.2 & 14.5 & 13.2 & 14.2 & 15.1 \\
\hline Combined ratio & $\ldots$ & $\ldots$ & $\ldots$ & $\ldots$ & $\ldots$ & $\ldots$ \\
\hline Investment income/investment assets & 4.1 & 3.0 & 2.3 & 2.9 & 3.7 & 3.0 \\
\hline Solvency ratio & 396.6 & 380.0 & 354.8 & 389.7 & 400.3 & 430.4 \\
\hline \multicolumn{7}{|l|}{ Non-life insurance } \\
\hline Total premimums (euro millions) & 8,912 & 9,220 & 9,200 & 9,102 & 9,685 & 10,387 \\
\hline Pre-tax earnings/net premium & 11.0 & 11.6 & 7.1 & 7.9 & 10.3 & 11.0 \\
\hline Loss ratio & 67.6 & 67.1 & 68.7 & 73.2 & 65.2 & 63.9 \\
\hline Expense ratio & 27.4 & 27.9 & 27.8 & 27.4 & 27.4 & 27.9 \\
\hline Combined ratio & 95.0 & 94.9 & 96.5 & 100.6 & 92.7 & 91.8 \\
\hline Investment income/investment assets & 7.1 & 6.2 & 3.7 & 3.8 & 3.9 & 4.1 \\
\hline Solvency ratio & 361.2 & 438.6 & 551.7 & 578.4 & 619.2 & 592.5 \\
\hline
\end{tabular}


Figure 14. Recent Economic Developments

Growth compares favorably to Euro area...

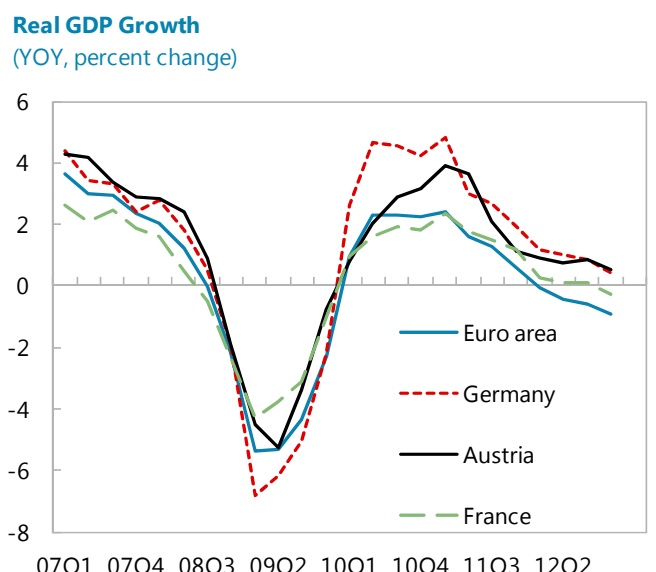

...and unemployment remained low throughout the crisis.

Harmonized Unemployment Rate

(Percent)

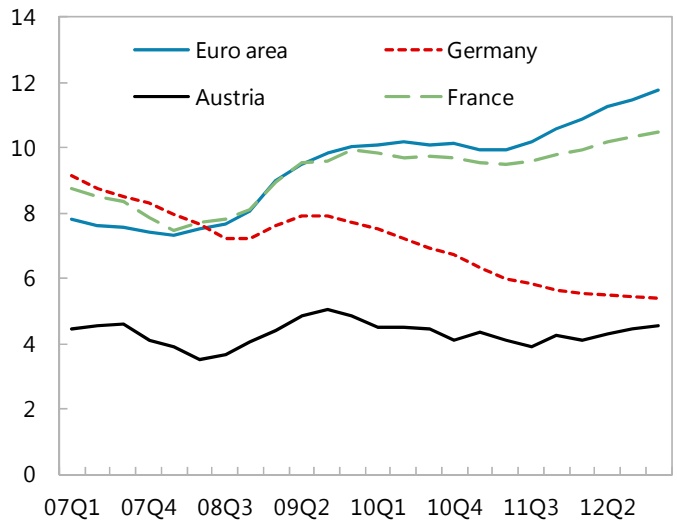

Credit growth remains subdued...
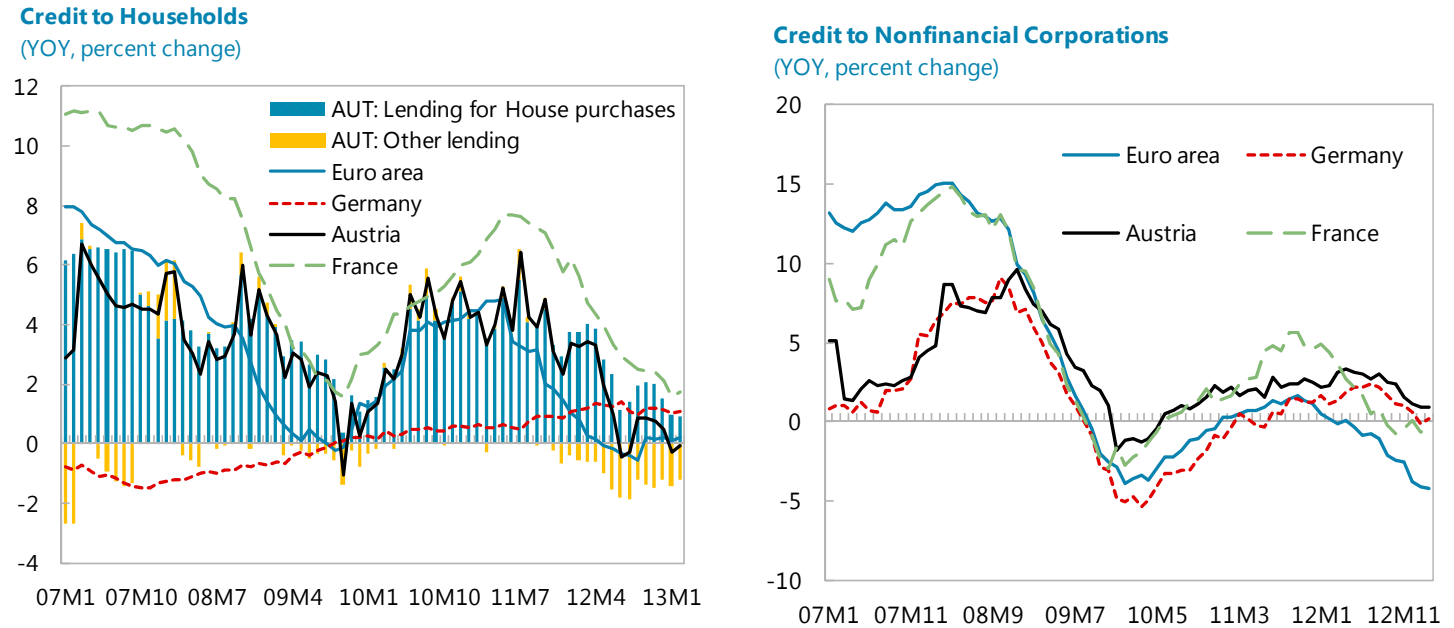

...while there are pockets of house price froth.

Real Property Prices

(Index, $2000=100$ )

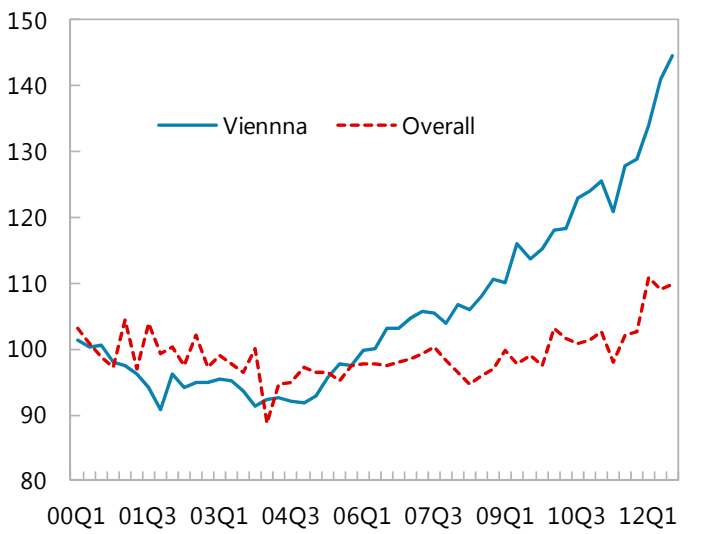

House Price Index - deflated

(YOY, percent change)

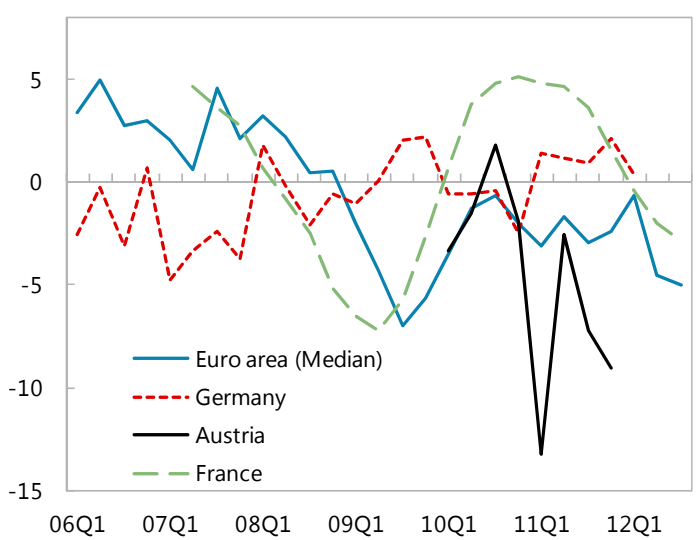

Sources: Haver; Eurostat, ECB; European Commission; and IMF Staff calculations. 
Figure 15. Sectoral Debt

Private debt levels are moderate

Household Debt

(Percent of GDP)

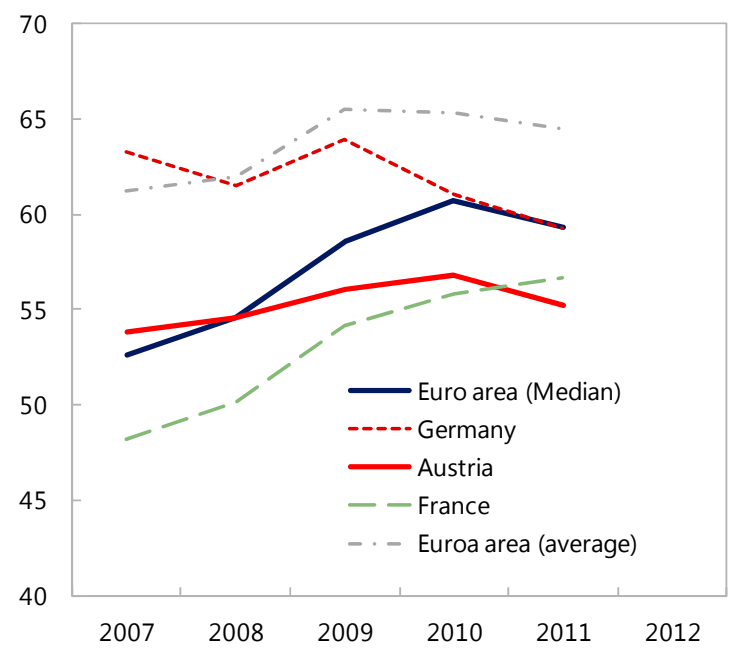

Public debt was propped up during the crisis...

General Government Debt

(Percent of GDP)

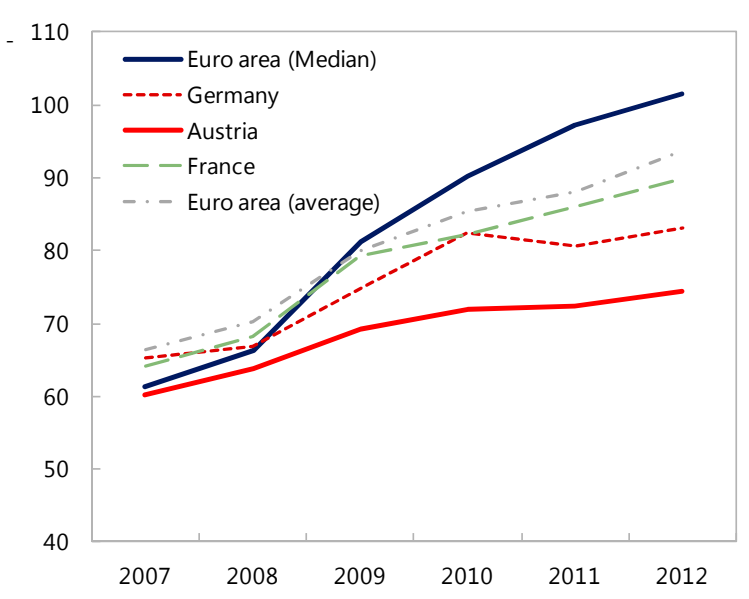

Corporate Debt

(Percent of GDP)

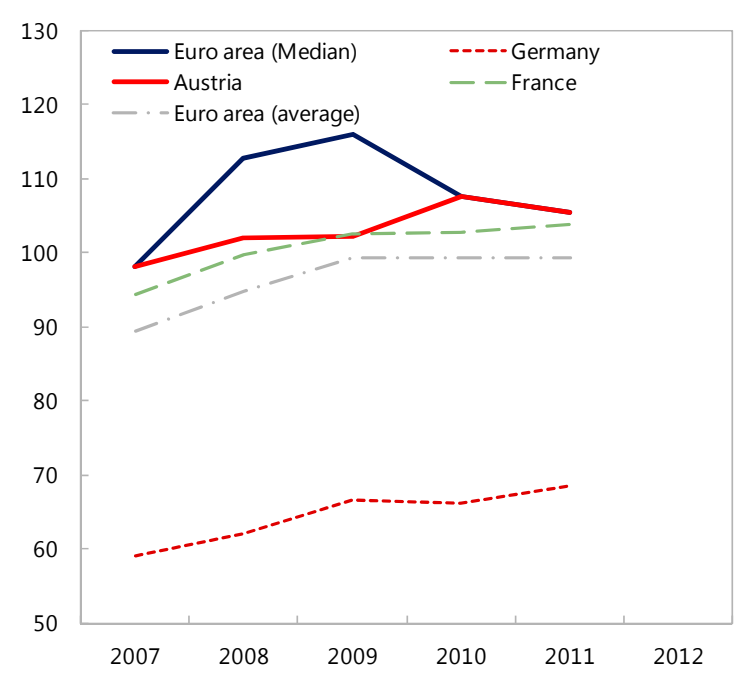

...but fiscal consolidation has strengthened.

General Government Deficit (Percent of GDP)

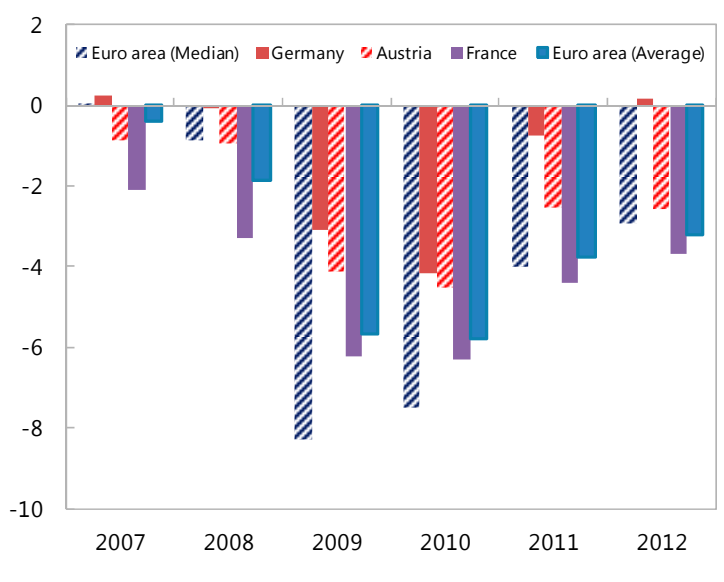

Sources: IMF WEO; and IMF Staff calculations. 


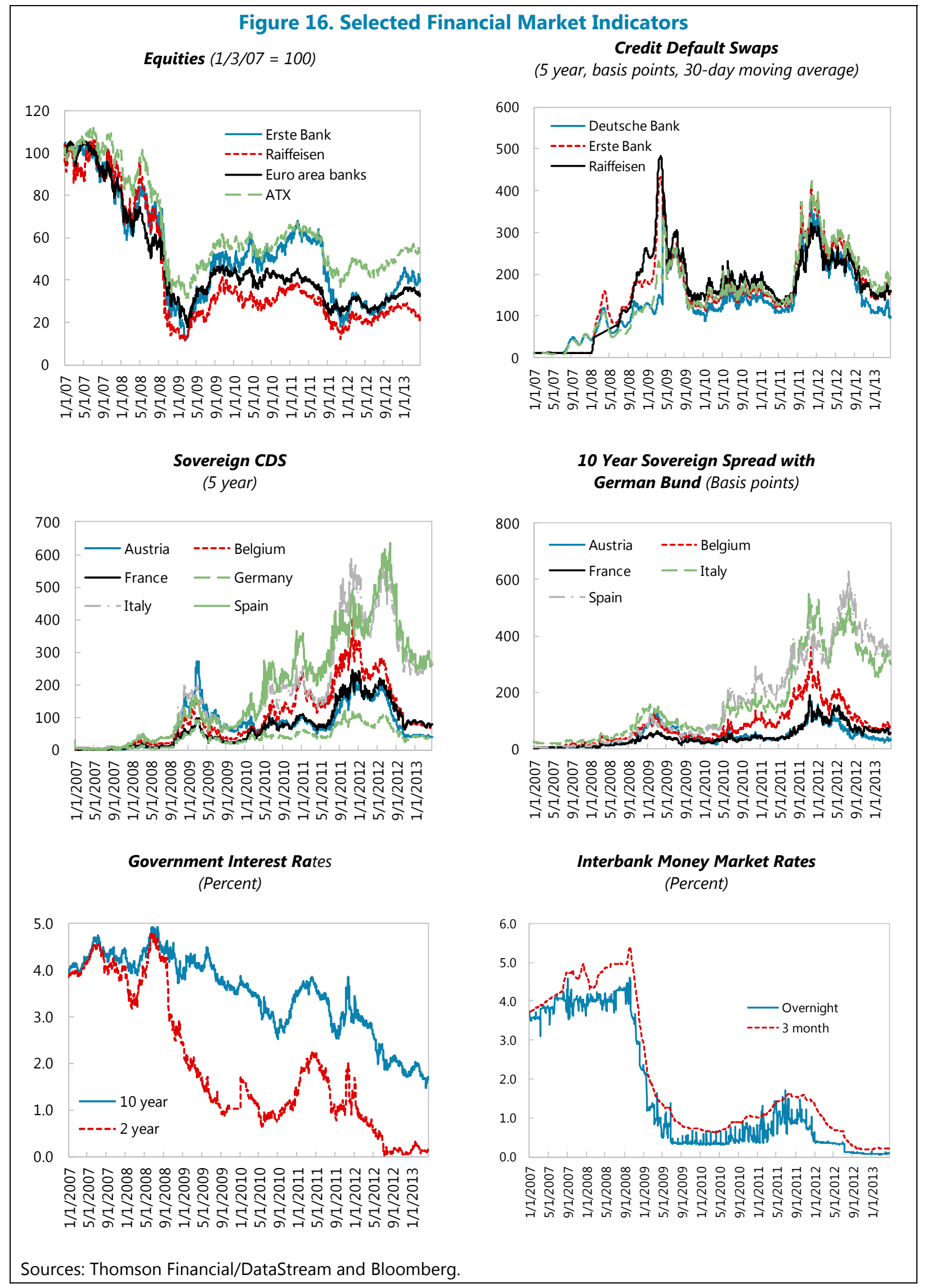




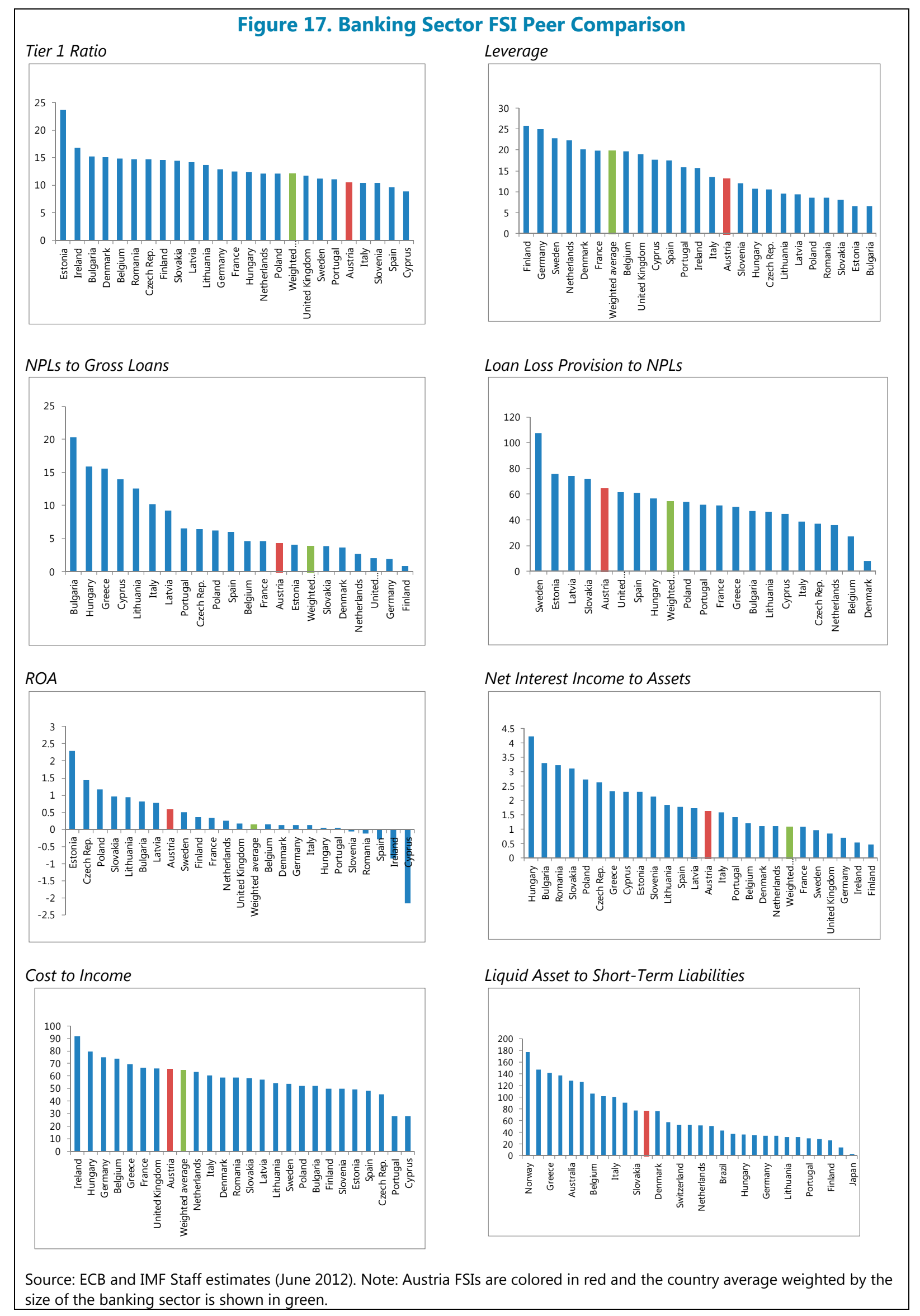


Figure 18. Solvency Stress Test Results-CT1 Capital Buckets Top-Down Test: Baseline Scenario

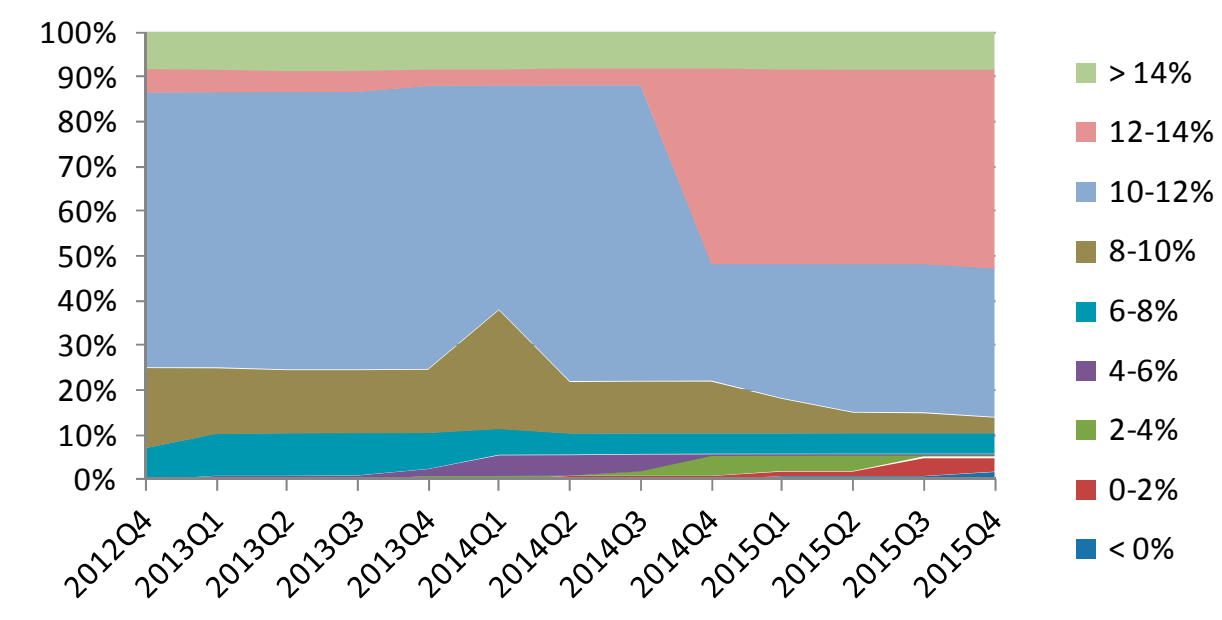

Top-Down Test: Global Shock Scenario

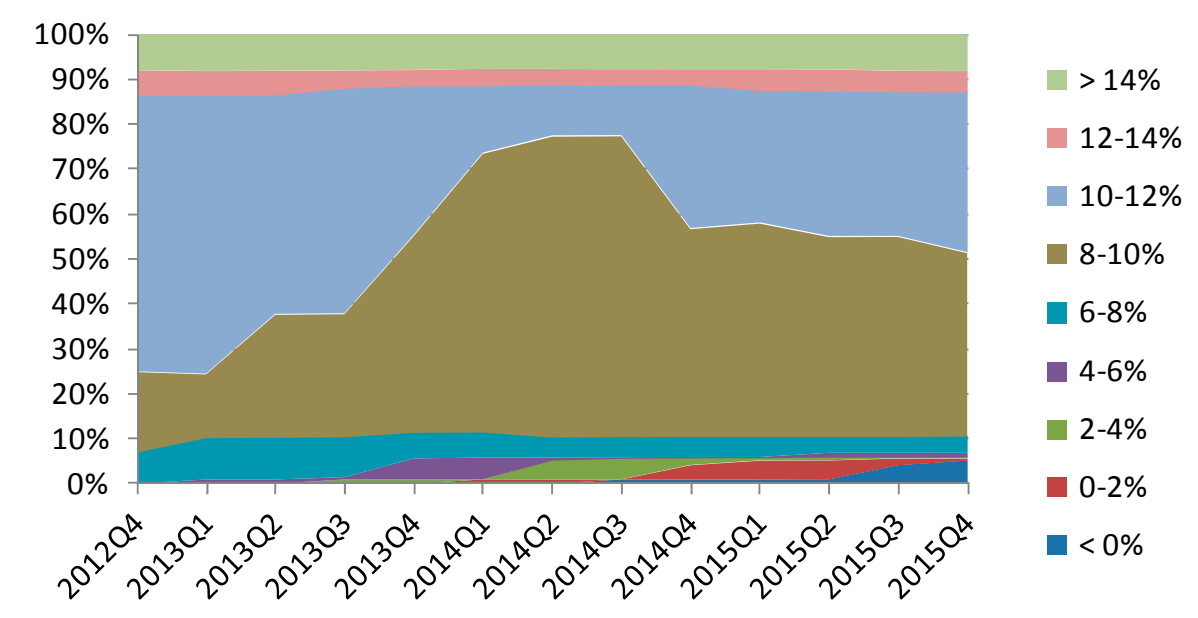

Top-Down Test: Global Shock/Recession in CESEE Scenario

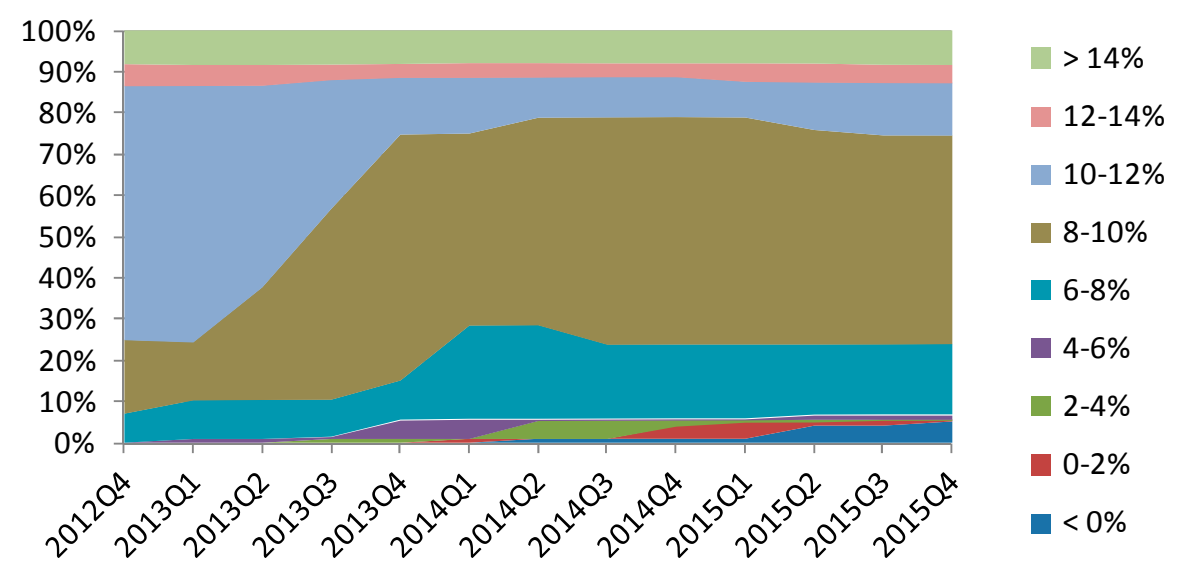

Source: National Bank of Austria and IMF. 
Figure 19. Solvency Stress Test Results—CT1 Ratio Distribution Top-Down Test: Baseline Scenario (in percent)

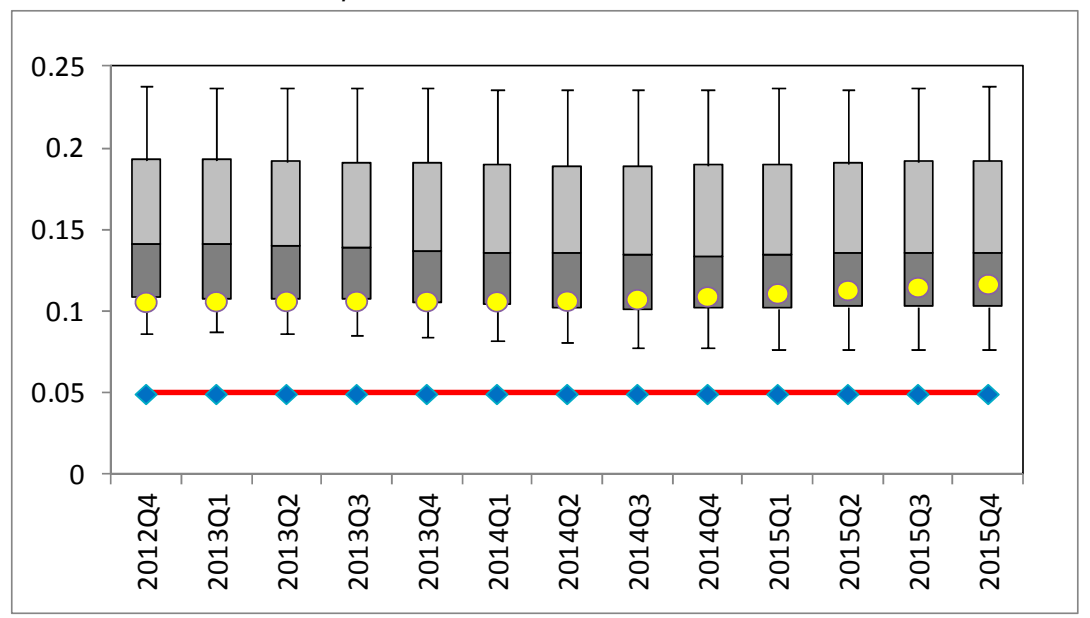

Top-Down Test: Global Shock Scenario (in percent)

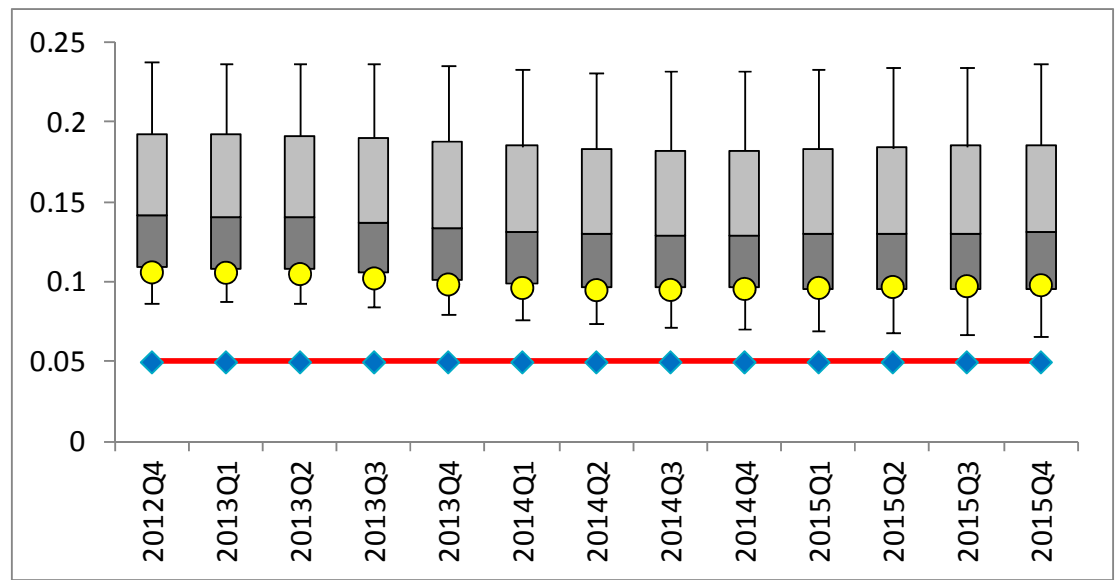

Top-Down Test: Global Shock/Recession in CESEE Scenario (in percent)

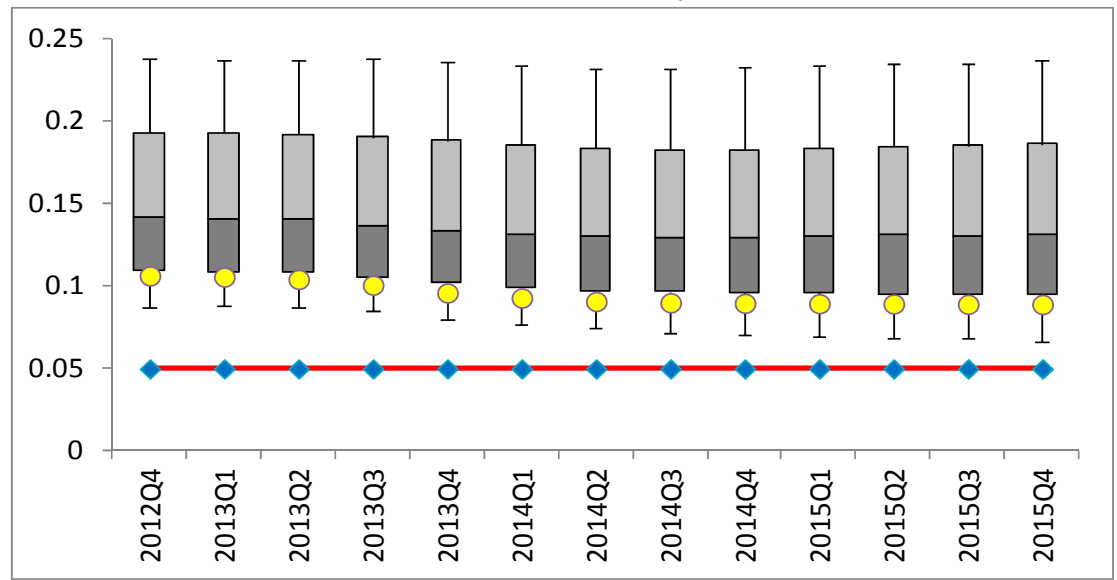

Source: OeNB and IMF estimates. The solvency stress test is conducted over the whole banking sector on a consolidated basis. Box plots include the mean (yellow dot), the 25 th and $75 \%$ percentile (shaded area), and the 10th and 90th percentiles (whiskers). The line reflects the hurdle rate. 
Figure 20. Capital Adequacy Ratios-Sensitivity Analysis

Whole banking sector

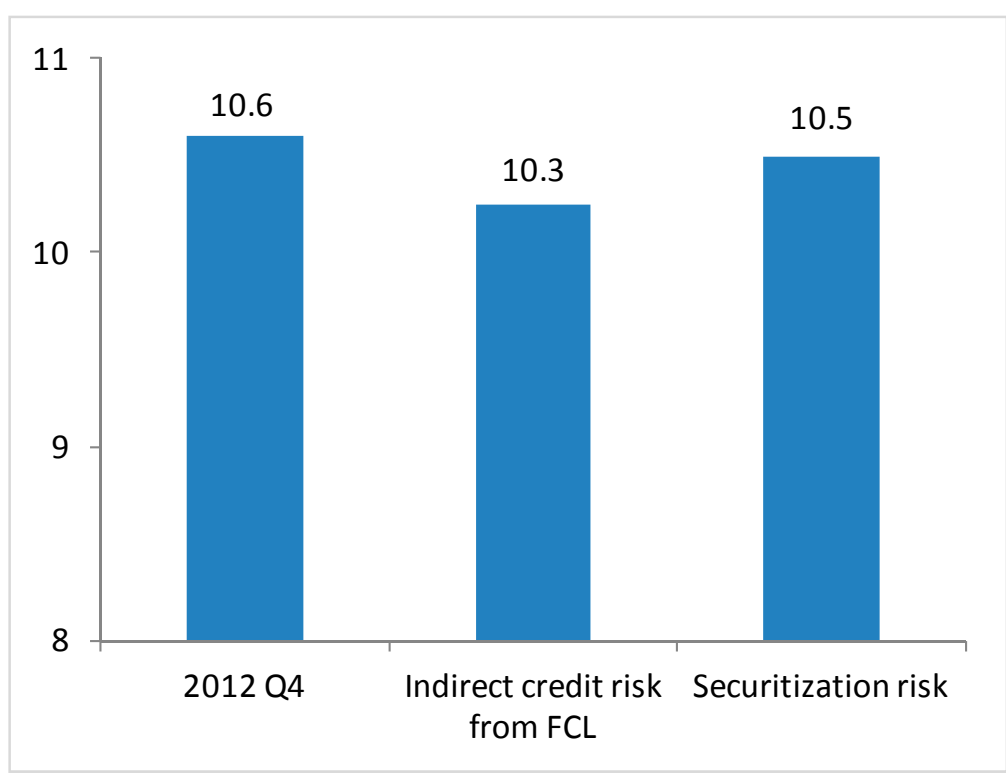

Top 5 banking institutions

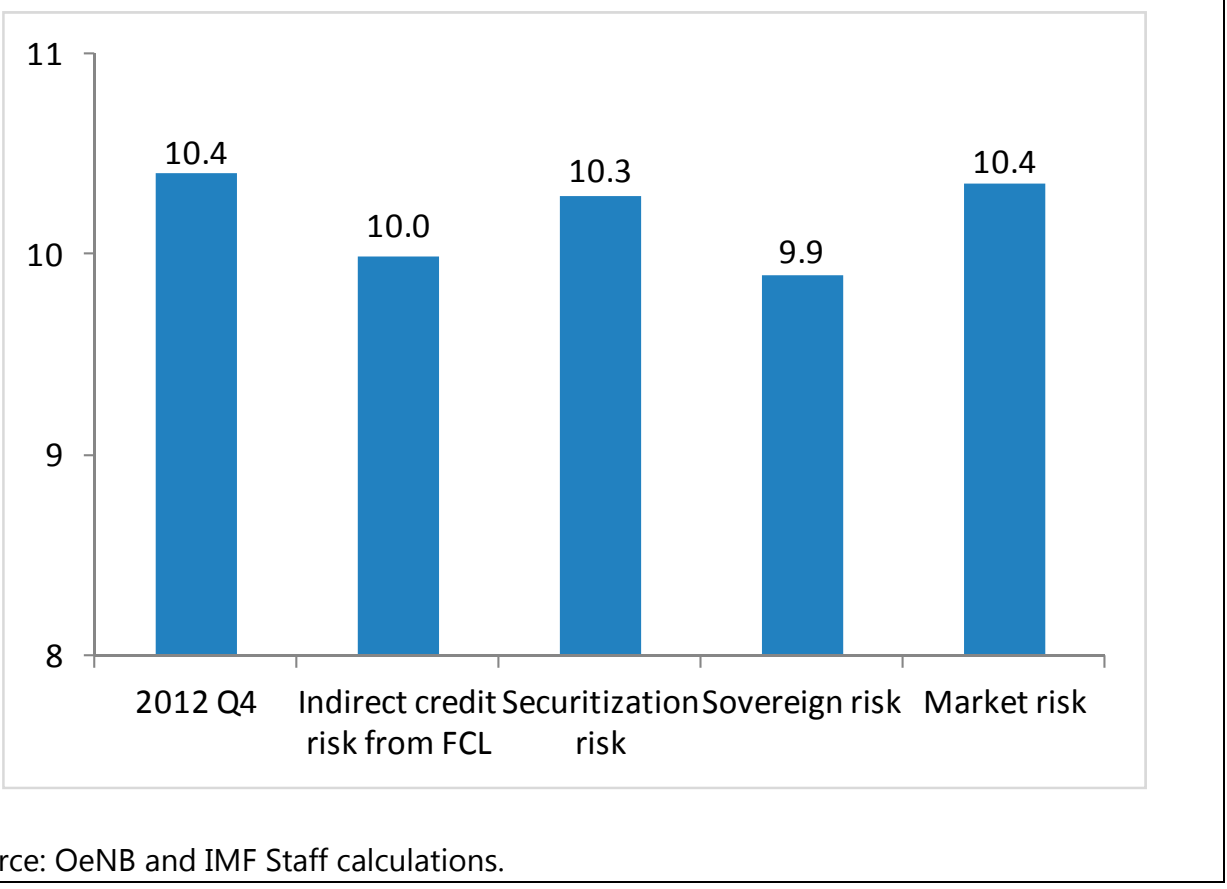


Figure 21. Systemic Risk in the CESEE Region

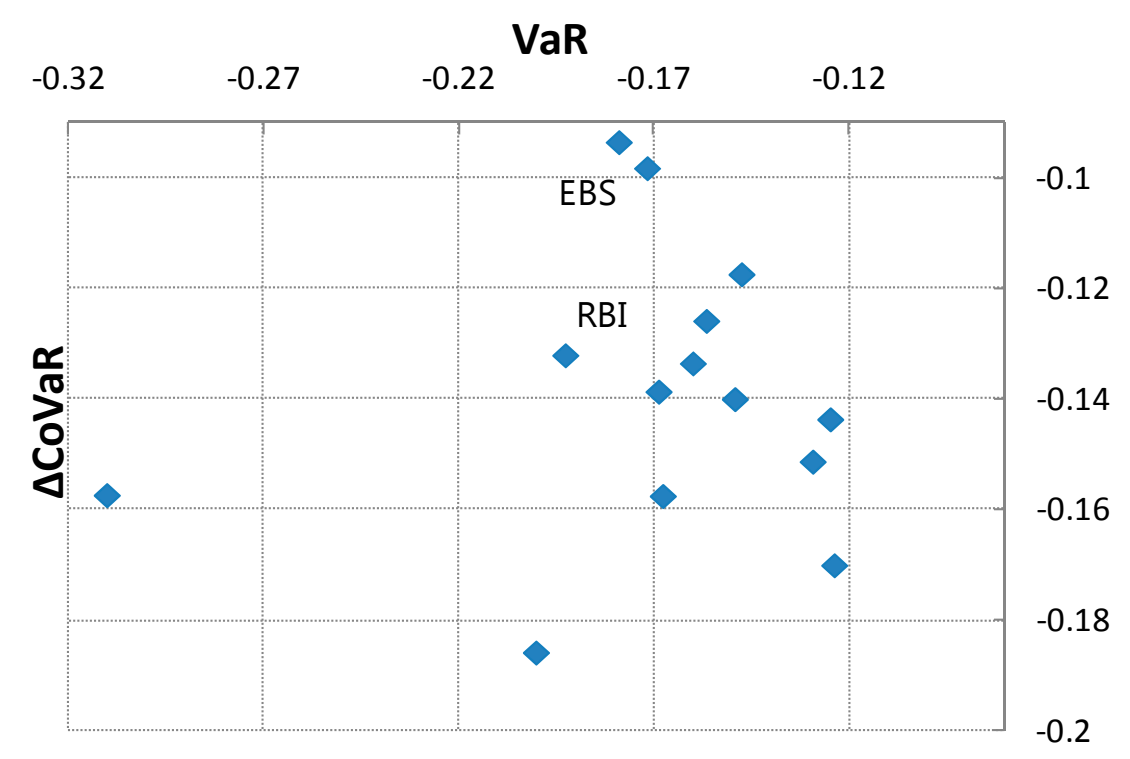

Source: IMF Staff calculations

Note: The sample includes fourteen international banks active in the CESEE region (based on both absolute exposure and share of CESEE operations in consolidated assets), including two Austrian banks, namely Erste Group (EBS), and Raiffeisen Bank International (RBI). The scatter plot shows the link between banks' solvency risk (measured by their $\mathrm{VaR})$ and their contribution to systemic risk ( $\triangle \mathrm{CoVaR}$ ). The latter captures how much risk an individual bank adds to overall distress of the banking system when it reaches its VaR. Both measures are averages of weekly market asset valued returns over 2005-2012, controlling for financial state variables. 


\section{Appendix I. Implementation of the Key Recommendations of 2007 FSAP Update}

\begin{tabular}{|c|c|c|}
\hline Priority & All Sectors & Implementation \\
\hline High & $\begin{array}{l}\text { Continue to develop cooperation with } \\
\text { foreign home and host supervisors. }\end{array}$ & Implemented \\
\hline High & $\begin{array}{l}\text { Define government institutional liability for } \\
\text { financial sector supervision more narrowly. }\end{array}$ & In progress \\
\hline High & $\begin{array}{l}\text { Intensify the on-site inspection program } \\
\text { and complementary off-site analysis and } \\
\text { monitoring. }\end{array}$ & Implemented \\
\hline High & $\begin{array}{l}\text { Enhance supervisory staff resources and } \\
\text { expertise. }\end{array}$ & Implemented \\
\hline Medium & $\begin{array}{l}\text { Raise administrative fines to European } \\
\text { standards. }\end{array}$ & Implemented \\
\hline Medium & $\begin{array}{l}\text { Define the responsibilities of external } \\
\text { auditors in line with supervisory priorities. }\end{array}$ & Fully implemented \\
\hline Medium & $\begin{array}{l}\text { Promote the periodic rotation of external } \\
\text { audit firms. }\end{array}$ & Fully implemented \\
\hline \multicolumn{3}{|l|}{ Banking } \\
\hline High & $\begin{array}{l}\text { Have the FMA and the OeNB publicly } \\
\text { acknowledge their common commitment } \\
\text { to cooperate very closely in bank } \\
\text { regulation and supervision, and corrective } \\
\text { action and enforcement, and enshrine the } \\
\text { commitment in operating procedures. }\end{array}$ & Implemented \\
\hline High & $\begin{array}{l}\text { Intensify coordinated or joint inspections } \\
\text { with foreign supervisors, and joint risk } \\
\text { assessments of groups, followed by joint } \\
\text { supervisory plans. }\end{array}$ & Ongoing \\
\hline High & $\begin{array}{l}\text { Follow up the planned crisis management } \\
\text { exercise with peers in CESE countries with } \\
\text { an exercise involving countries farther } \\
\text { afield where Austrian banks are active. }\end{array}$ & $\begin{array}{l}\text { Implemented and } \\
\text { ongoing }\end{array}$ \\
\hline High & $\begin{array}{l}\text { Ensure that banks continue to manage } \\
\text { indirect credit risk stemming from foreign } \\
\text { currency loans ( } \mathrm{FCL}) \text {, both domestically and } \\
\text { abroad, and promote borrowers' awareness } \\
\text { of the risks. }\end{array}$ & In progress \\
\hline High & $\begin{array}{l}\text { Set up a system mandating early remedial } \\
\text { action when warning signs are detected. }\end{array}$ & In progress \\
\hline High & Further develop stress testing, focusing & Fully implemented \\
\hline
\end{tabular}




\begin{tabular}{|c|c|c|}
\hline & $\begin{array}{l}\text { especially on links between credit quality } \\
\text { and macroeconomic performance in all } \\
\text { markets where Austrian banks operate. }\end{array}$ & \\
\hline Medium & $\begin{array}{l}\text { Give the FMA greater authority to object to } \\
\text { group structures that impede effective } \\
\text { supervision and corporate governance. }\end{array}$ & In progress \\
\hline Medium & $\begin{array}{l}\text { Reconsider current exemptions of small } \\
\text { banks from some corporate governance } \\
\text { regulations. }\end{array}$ & $\begin{array}{l}\text { Not implemented (in } \\
\text { the context of fit and } \\
\text { proper tests). }\end{array}$ \\
\hline \multicolumn{3}{|c|}{$\begin{array}{l}\text { Insurance, Pensions, and } \\
\text { Securities }\end{array}$} \\
\hline High & $\begin{array}{l}\text { Abolish the current restriction that } 30 \\
\text { percent of contributions in } \\
\text { Zukunftsvorsorge funds must be invested } \\
\text { in European Economic Area stock markets } \\
\text { with low market capitalization. }\end{array}$ & Fully implemented \\
\hline High & $\begin{array}{l}\text { Become a full signatory to the International } \\
\text { Organization of Securities Commission } \\
\text { (IOSCO) Multilateral Memorandum of } \\
\text { Understanding. }\end{array}$ & Fully implemented \\
\hline Medium & $\begin{array}{l}\text { Ensure that tax and regulatory policies are } \\
\text { neutral across otherwise comparable } \\
\text { savings vehicles to support competition. }\end{array}$ & Implemented \\
\hline Medium & $\begin{array}{l}\text { Support the expansion of the supply of } \\
\text { well-trained actuaries. }\end{array}$ & Fully implemented \\
\hline Medium & $\begin{array}{l}\text { Extend stress testing of insurance } \\
\text { companies' and pension funds' liabilities } \\
\text { and investigate the use of market-based } \\
\text { soundness indicators. }\end{array}$ & Fully implemented \\
\hline
\end{tabular}




\section{Appendix II. Risk Assessment Matrix (RAM)}

\begin{tabular}{|c|c|c|}
\hline \multirow[b]{2}{*}{$\begin{array}{l}\text { Nature / Source } \\
\text { of Main Threats }\end{array}$} & \multicolumn{2}{|c|}{ Overall Level of Concern } \\
\hline & $\begin{array}{c}\text { Likelihood of Realization of Threat in the } \\
\text { Next 1-3 Years } \\
\text { (high, medium or low) }\end{array}$ & $\begin{array}{l}\text { Expected Impact on Financial Stability if Threat } \\
\text { is Realized } \\
\text { (high, medium or low) }\end{array}$ \\
\hline $\begin{array}{l}\text { 1. Global } \\
\text { shock/ } \\
\text { Intensification } \\
\text { of the Euro } \\
\text { Area debt crisis }\end{array}$ & $\begin{array}{l}\text { Medium } \\
\text { The IMF's Global Risk Assessment Matrix } \\
\text { assigns a low/medium probability to a } \\
\text { sharp slowdown in global growth or } \\
\text { subdued domestic demand in the hard-hit } \\
\text { euro zone periphery countries. }\end{array}$ & $\begin{array}{l}\text { High } \\
\text { - A global/euro area slowdown would decrease } \\
\text { demand for Austrian exports and trigger a } \\
\text { slowdown in the CESEE/CIS region, resulting in } \\
\text { higher NPLs, lower profitability, and potential } \\
\text { solvency pressures in some institutions. In turn, } \\
\text { the fiscal impact of financial sector-related } \\
\text { public liabilities may trigger adverse market } \\
\text { dynamics. } \\
\text { In addition, tight funding conditions could affect } \\
\text { some Austrian banks if European banks } \\
\text { accelerate deleveraging, hoard liquidity and cut } \\
\text { interbank lending. } \\
\text { Safe haven strategies by international investors } \\
\text { may lead to sudden CHF appreciation (despite } \\
\text { SNB interventions), heightening credit risk from } \\
\text { FX lending to domestic borrowers. } \\
\text { The authorities have already taken steps to } \\
\text { promote local funding and to decrease the flow } \\
\text { of FX lending in Austria. }\end{array}$ \\
\hline $\begin{array}{l}\text { 2. Contagion } \\
\text { to/from CESEE } \\
\text { countries }\end{array}$ & $\begin{array}{l}\text { Medium } \\
\text { - Several large CESEE countries may be } \\
\text { subject to severe macroeconomic and } \\
\text { financial shocks. The highest Austrian } \\
\text { bank exposures are to the Czech Republic, } \\
\text { Croatia, Romania, Slovakia and Hungary. } \\
\text { Banks also carry large exposure to FCL in } \\
\text { host countries. }\end{array}$ & $\begin{array}{l}\text { Medium } \\
\text { The Austrian banking system is a major gateway } \\
\text { to CESEE, providing significant cross-border } \\
\text { lending both relative to Austrian banks and to } \\
\text { local markets. Thus, and despite ongoing shifts } \\
\text { in country exposures, a sharp slowdown in } \\
\text { CESEE countries would likely result in higher } \\
\text { NPLs, lower profitability, and potential solvency } \\
\text { problems for Austrian banks. } \\
\text { - Local currency depreciation in host countries } \\
\text { could raise debt burdens of borrowers, also } \\
\text { raising NPL levels for Austrian banks. } \\
\text { - Accelerated deleveraging in CESEE by Austrian }\end{array}$ \\
\hline
\end{tabular}




\begin{tabular}{|c|c|c|}
\hline \multirow[b]{2}{*}{$\begin{array}{l}\text { Nature / Source } \\
\text { of Main Threats }\end{array}$} & \multicolumn{2}{|c|}{ Overall Level of Concern } \\
\hline & $\begin{array}{c}\text { Likelihood of Realization of Threat in the } \\
\text { Next 1-3 Years } \\
\text { (high, medium or low) }\end{array}$ & $\begin{array}{l}\text { Expected Impact on Financial Stability if Threat } \\
\text { is Realized } \\
\text { (high, medium or low) }\end{array}$ \\
\hline & & $\begin{array}{l}\text { banks could fuel a negative feedback loop, } \\
\text { possibly involving the two effects above. In turn, } \\
\text { the fiscal impact of financial sector-related } \\
\text { public liabilities may trigger adverse market } \\
\text { dynamics. }\end{array}$ \\
\hline $\begin{array}{l}\text { 3. Severe } \\
\text { Funding Stress } \\
\text { of Global Banks }\end{array}$ & $\begin{array}{l}\text { Medium } \\
\text { - Given the still fragile environment globally } \\
\text { and in the euro area, there is a significant } \\
\text { risk that some global banks may be hit by } \\
\text { renewed disruption in international } \\
\text { funding and foreign currency swap } \\
\text { markets, reinforcing home bias shifts and } \\
\text { tightening cross-border funding for } \\
\text { Austrian banks. }\end{array}$ & $\begin{array}{l}\text { Medium } \\
\text { - Significant net cash outflows would trigger } \\
\text { higher haircuts and unexpected margin calls on } \\
\text { Austrian banks securities portfolios. } \\
\text { - Austrian banks may pass on rising funding costs } \\
\text { to customers, and cut activities with high risk } \\
\text { weights, exacerbating the credit crunch. This } \\
\text { effect would be particularly severe for banks } \\
\text { with negative funding gaps in USD and CHF. } \\
\text { Liquidity support from the ECB, repo operations } \\
\text { conducted by the SNB, and swap facilities } \\
\text { provided by the SNB and the ECB, may mitigate } \\
\text { funding pressures in secured and unsecured } \\
\text { money markets. Moreover, the FX-liquidity } \\
\text { position of the system has substantially } \\
\text { improved since } 2008 \text { through the lengthening of } \\
\text { tenors and diversification of counterparties. }\end{array}$ \\
\hline
\end{tabular}




\section{Appendix III. Stress Test Matrix (STeM) For the Banking Sector}

\begin{tabular}{|c|c|c|c|}
\hline \multicolumn{2}{|c|}{ Domain } & ‘Bottom-Up by Banks & $\begin{array}{l}\text { Top-Down by OeNB with } \\
\text { FSAP Team Inputs }\end{array}$ \\
\hline \multicolumn{4}{|c|}{ Banking Sector: Solvency Risk } \\
\hline \multirow[t]{3}{*}{$\begin{array}{l}\text { 1.Institutional } \\
\text { Perimeter }\end{array}$} & Institutions included & - Five largest banks. & $\begin{array}{l}\text { - All banking institutions: } \\
\text { approx. } 585 \text { consolidated. }\end{array}$ \\
\hline & Market share & $\begin{array}{l}\text { - Two thirds of banking sector } \\
\text { assets. }\end{array}$ & $\begin{array}{l}\text { - } 100 \text { percent of banking } \\
\text { sector assets. }\end{array}$ \\
\hline & $\begin{array}{l}\text { Data and baseline } \\
\text { date }\end{array}$ & $\begin{array}{l}\text { - Institutions' own data as of } \\
\text { Q4 } 2012 . \\
\text { - Consolidated banking group. }\end{array}$ & $\begin{array}{l}\text { - Supervisory data as of Q4 } \\
2012 \text {. } \\
\text { - Consolidated banking group. }\end{array}$ \\
\hline \multirow{3}{*}{$\begin{array}{l}\text { 2. Channels of } \\
\text { Risk Propagation }\end{array}$} & Methodology & - Banks' internal models. & - OeNB Balance-sheet model. \\
\hline & $\begin{array}{l}\text { Satellite Models for } \\
\text { Macrofinancial } \\
\text { linkages }\end{array}$ & $\begin{array}{l}\text { - Internal models for market } \\
\text { risk. }\end{array}$ & $\begin{array}{l}\text { - Separate satellite model for } \\
\text { the Austrian (using } \\
\text { insolvency data across six } \\
\text { industry sectors) and the } \\
\text { CESEE/CIS portfolio (using } \\
\text { LLPR data broken down by } \\
\text { currency), linking PDs/LGDs } \\
\text { with macro scenarios. } \\
\text { - Stressed PDs and LGDs. } \\
\text { - OeNB consensus rating } \\
\text { across banks applied to } \\
\text { single loans. } \\
\text { - Solvency and funding } \\
\text { interactions included. }\end{array}$ \\
\hline & Stress test horizon & - Instantaneous & - 2013-2015 \\
\hline 3. Tail shocks & Scenario analysis & & $\begin{array}{l}\text { - Global Slowdown/Euro Area } \\
\text { Debt Crisis. Deviation of 2- } \\
\text { year accumulated growth } \\
\text { rate of } 2.0 \text { SD for the } \\
\text { Austrian economy and } 1.5 \\
\text { SD for the CESEE/CIS region. } \\
\text { Country specific projections } \\
\text { developed for twenty-two } \\
\text { CESEE/CIS countries. } \\
\text { - Recession in the CESEE/CIS } \\
\text { region. Country-specific add- } \\
\text { on shocks are applied to } \\
\text { seven countries raising the } \\
\text { overall size of the shock to }\end{array}$ \\
\hline
\end{tabular}




\begin{tabular}{|c|c|c|c|}
\hline \multicolumn{2}{|c|}{ Domain } & \multirow[t]{2}{*}{ ‘Bottom-Up by Banks } & \multirow{2}{*}{$\begin{array}{l}\text { Top-Down by OeNB with } \\
\text { FSAP Team Inputs } \\
\text { 1.7 SD for CESEE and 1.8 for } \\
\text { CIS. } \\
\text { - Global Funding Scenario } \\
\text { (domestic currency, } \\
\text { Eurocurrency, deposit runs, } \\
\text { FX swap markets, market } \\
\text { issuances) calibrated to Q3 } \\
\text { 2008. }\end{array}$} \\
\hline & & & \\
\hline & Sensitivity analysis & $\begin{array}{l}\text { - Market risk applied to } \\
\text { trading book positions as of } \\
\text { Dec } 2012 \text {. Valuation effects } \\
\text { reported for a wide spectrum } \\
\text { of stressed risk parameters. } \\
\text { - Sovereign risk in both } \\
\text { banking and trading book, } \\
\text { including of CESEE } \\
\text { subsidiaries (government, } \\
\text { regional, and local } \\
\text { authorities) applied to } 64 \\
\text { countries, across all } \\
\text { remaining maturities (3m, } \\
6 \mathrm{~m}, 1 \mathrm{y}-10 \mathrm{y}, 15 \mathrm{y}, 20 \mathrm{y}, 30 \mathrm{y}) \text {. }\end{array}$ & $\begin{array}{l}\text { - Credit risk from foreign } \\
\text { currency lending for Austrian } \\
\text { exposures, cross-border } \\
\text { lending, and the loan book } \\
\text { of CESEE subsidiaries } \\
\text { (assumption: } 1.5 \text { SD of CHF). } \\
\text { - Funding risk for deposits and } \\
\text { capital market issuance } \\
\text { calibrated to 2008Q3- } \\
\text { 2009Q1. } \\
\text { - Securitization portfolio } \\
\text { following 2011 EBA } \\
\text { methodology. } \\
\text { - Market risk from } \\
\text { underperformance of } \\
\text { repayment vehicles and FX } \\
\text { appreciation. }\end{array}$ \\
\hline \multirow[t]{2}{*}{$\begin{array}{l}\text { 4.Risks and } \\
\text { Buffers }\end{array}$} & Risks/factors assessed & $\begin{array}{l}\text { - Market risk parameters: } \\
\text { interest rates (23), major FX } \\
\text { (8), equity indices (15), } \\
\text { commodities (4), credit } \\
\text { spreads (8), and } \\
\text { counterparty risk (2). }\end{array}$ & $\begin{array}{l}\text { - Credit losses, operating } \\
\text { profits, funding costs, } \\
\text { performance of repayment } \\
\text { vehicles, sovereign risk, } \\
\text { counterparty risk, exchange } \\
\text { rate, taxes. } \\
\text { - Full implementation of Basel } \\
\text { III phase-in arrangements on } \\
\text { aggregate CET1. }\end{array}$ \\
\hline & $\begin{array}{l}\text { Behavioral } \\
\text { adjustments }\end{array}$ & & $\begin{array}{l}\text { - Constant balance sheet. } \\
\text { - No asset disposals allowed } \\
\text { - No credit growth assumed. }\end{array}$ \\
\hline $\begin{array}{l}\text { 5. Regulatory and } \\
\text { Market-Based } \\
\text { Standards and } \\
\text { Parameters }\end{array}$ & $\begin{array}{l}\text { Calibration of risk } \\
\text { parameters }\end{array}$ & $\begin{array}{l}\text { - Major interest rates and FX } \\
\text { rates jointly determined with } \\
\text { the macro adverse scenario } \\
\text { for consistency. } \\
\text { - EBA's EU-wide stress test } \\
\text { 2011, historical volatility, and }\end{array}$ & $\begin{array}{l}\text { - Stressed PDs and LGDs: } \\
\text { - They are applied to compute } \\
\text { both credit losses and } \\
\text { stressed RWA calculations. }\end{array}$ \\
\hline
\end{tabular}




\begin{tabular}{|c|c|c|c|}
\hline \multicolumn{2}{|c|}{ Domain } & \multirow{2}{*}{$\begin{array}{l}\text { 'Bottom-Up by Banks } \\
\text { expert judgment for the } \\
\text { remaining risk factors. }\end{array}$} & \multirow[t]{2}{*}{$\begin{array}{c}\text { Top-Down by OeNB with } \\
\text { FSAP Team Inputs }\end{array}$} \\
\hline & & & \\
\hline & $\begin{array}{l}\text { Regulatory/Accountin } \\
\mathrm{g} \text { and Market-Based } \\
\text { Standards }\end{array}$ & & $\begin{array}{l}\text { - Capital definition according } \\
\text { to EBA CT1 and Basel } 2.5 \\
\text { RWAs. } \\
\text { - Estimates of Basel III capital } \\
\text { ratios (CET1, Tier 1, CAR) and } \\
\text { RWAs for top 3, and whole } \\
\text { banking system. } \\
\text { - Hurdle rate: EBA's Core Tier } \\
1 \text { (5 percent), Tier } 1 \text { ( } 6 \\
\text { percent), and CAR (8 } \\
\text { percent) for whole banking } \\
\text { system } \\
\text { - Aggregate estimate of CET1 } \\
\text { ratio for large } \\
\text { internationally-active banks. }\end{array}$ \\
\hline $\begin{array}{l}\text { 6. Reporting } \\
\text { Format for } \\
\text { Results }\end{array}$ & Output presentation & $\begin{array}{l}\text { - Dispersion of valuation } \\
\text { losses. } \\
\text { - Absolute and in terms of } \\
\text { capital. }\end{array}$ & $\begin{array}{l}\text { - Distribution of capital ratios. } \\
\text { - Percentage of assets in } \\
\text { capital buckets. } \\
\text { - Weighted average capital } \\
\text { ratios. } \\
\text { - Percentage of assets that fail. } \\
\text { Recapitalization needs. }\end{array}$ \\
\hline
\end{tabular}

\begin{tabular}{|c|c|c|}
\hline \multicolumn{2}{|c|}{ Domain } & Top-Down by OeNB in collaboration with FSAP Team \\
\hline \multicolumn{3}{|r|}{ Banking Sector: Liquidity Risk } \\
\hline \multirow[t]{3}{*}{$\begin{array}{l}\text { 1. Institutional } \\
\text { Perimeter }\end{array}$} & $\begin{array}{l}\text { Institutions } \\
\text { included }\end{array}$ & $\begin{array}{l}\text { - } 29 \text { banking institutions. } \\
\text { - All banking institutions subject to weekly cash-flow based liquidity } \\
\text { reporting. }\end{array}$ \\
\hline & Market share & - 80 percent of banking sector assets. \\
\hline & $\begin{array}{l}\text { Data and } \\
\text { baseline date }\end{array}$ & $\begin{array}{l}\text { - Supervisory data as of Q4 } 2012 \text {. } \\
\text { - Consolidated banking group. } \\
\text { - Granular data based on contractual and behavioral expected cash- } \\
\text { flows over five maturity buckets ( } 5 \text { days, } 1 \mathrm{~m}, 3 \mathrm{~m}, 6 \mathrm{~m} \text {, and } 12 \mathrm{~m} \text { ). }\end{array}$ \\
\hline
\end{tabular}




\begin{tabular}{|c|c|c|}
\hline \multicolumn{2}{|c|}{ Domain } & \multirow{2}{*}{$\begin{array}{l}\text { Top-Down by OeNB in collaboration with FSAP Team } \\
\text { - Cash-flow-based using } 6 \text { major currency buckets. } \\
\text { - All scenarios are based on the underlying macroeconomic scenarios } \\
\text { of the solvency stress test: (i) PD shifts feed into the } \\
\text { counterbalancing capacity and cash inflows; (ii) feedback effects are } \\
\text { included due to rising funding costs projected under the adverse } \\
\text { macro scenario. }\end{array}$} \\
\hline $\begin{array}{l}\text { 2. Channels of } \\
\text { Risk Propagation }\end{array}$ & Methodology & \\
\hline \multirow[t]{2}{*}{$\begin{array}{l}\text { 3.Risks and } \\
\text { Buffers }\end{array}$} & Risks & $\begin{array}{l}\text { - Impact of solvency on liquidity via three channels: NPL impact on } \\
\text { cash inflows via a credit risk migration matrix; capital ratios on cash } \\
\text { outflows (funding cost and rollover rates); asset quality on } \\
\text { counterbalancing capacity. } \\
\text { - Funding liquidity shock. } \\
\text { - Market liquidity shock. }\end{array}$ \\
\hline & Buffers & $\begin{array}{l}\text { - Counterbalancing capacity taking into account haircuts to liquid } \\
\text { assets. }\end{array}$ \\
\hline 4. Tail shocks & Size of the shock & $\begin{array}{l}\text { - Bank run and dry up of wholesale funding markets over } 45 \\
\text { scenarios including full/limited/restricted/closed access to money } \\
\text { markets covering funding in domestic currency, Eurocurrency } \\
\text { funding, FX swap markets. } \\
\text { - Scenarios are grouped into a baseline, market mild, market } \\
\text { medium, market severe, and combined scenario (including market } \\
\text { and idiosyncratic shocks). } \\
\text { - Detailed assumptions and results are reported for the mild market } \\
\text { scenario which is consistent with recent EU FSAPs liquidity stress } \\
\text { test scenarios. } \\
\text { - Instantaneous outflow of funding and gradual outflow over 30-day, } \\
\text { 90-day, and 1-year horizon. }\end{array}$ \\
\hline $\begin{array}{l}\text { 5. Regulatory and } \\
\text { Market-Based } \\
\text { Standards and } \\
\text { Parameters }\end{array}$ & $\begin{array}{l}\text { Regulatory } \\
\text { standards }\end{array}$ & $\begin{array}{l}\text { - Hurdle metrics: liquidity gap by major currency. } \\
\text { - Definition of liquidity: local regulatory requirements. } \\
\text { - Mapping with recent EU FSAP scenarios (stricter than revised Basel } \\
\text { III LCR) }\end{array}$ \\
\hline $\begin{array}{l}\text { 6. Reporting } \\
\text { Format for } \\
\text { Results }\end{array}$ & $\begin{array}{l}\text { Output } \\
\text { presentation }\end{array}$ & - Percentage of assets that fail under each horizon. \\
\hline
\end{tabular}

\begin{tabular}{|c|c|c|c|}
\hline Domain & & Top-Down by OeNB & Top-Down by FSAP Team \\
\hline \multicolumn{4}{|c|}{ Banking Sector: Contagion Risk } \\
\hline \multirow[t]{3}{*}{$\begin{array}{l}\text { 1.Institutional } \\
\text { Perimeter }\end{array}$} & $\begin{array}{l}\text { Institutions } \\
\text { included }\end{array}$ & $\begin{array}{l}\text { - Banks operating in the Austrian } \\
\text { interbank market. }\end{array}$ & $\begin{array}{l}\text { - Top listed Austrian banks and } \\
\text { major global European banks } \\
(40) \text { and in the CESEE (14) }\end{array}$ \\
\hline & Market share & $\begin{array}{l}\text { - All banking institutions: } 585 \\
\text { consolidated. }\end{array}$ & $\begin{array}{l}\text { - Ranging between } 40 \text { percent } \\
\text { and } 60 \text { percent of banking } \\
\text { system assets. }\end{array}$ \\
\hline & Data and & - Supervisory, data as of Q4 2012. & - Balance sheet, market data as \\
\hline
\end{tabular}




\begin{tabular}{|c|c|c|c|}
\hline \multicolumn{2}{|l|}{ Domain } & \multirow{2}{*}{$\begin{array}{l}\text { Top-Down by OeNB } \\
\text { - Unconsolidated exposures but } \\
\text { consolidated capital ratios. }\end{array}$} & \multirow{2}{*}{$\begin{array}{l}\text { Top-Down by FSAP Team } \\
\text { of Q4 } 2012 . \\
\text { - Consolidated basis. }\end{array}$} \\
\hline & baseline date & & \\
\hline $\begin{array}{l}\text { 2. Channels of } \\
\text { Risk Propagation }\end{array}$ & Methodology & $\begin{array}{l}\text { - Impact study of liquidity risk on } \\
\text { solvency risk. } \\
\text { - Network Analysis in the } \\
\text { Austrian interbank market using } \\
\text { a default cascade model. }\end{array}$ & $\begin{array}{l}\text { - CoVaR framework. } \\
\text { - Asymmetric response in } \\
\text { episodes of deleveraging. } \\
\text { - State variables include: a } \\
\text { volatility index, a liquidity } \\
\text { spread, changes in the short- } \\
\text { end and the slope of the yield } \\
\text { curve, changes in high-yield } \\
\text { credit spreads, and equity } \\
\text { market returns. } \\
\text { - European and US financial } \\
\text { variables considered. } \\
\text { - Tail co-dependence assessed } \\
\text { in (i) banks' market valued } \\
\text { assets' growth rates, and (ii) } \\
\text { banks' equity returns. } \\
\text { - Individual risk computed using } \\
\text { (i) a quantile approach, and (ii) } \\
\text { a GARCH (1,1) framework. }\end{array}$ \\
\hline 3. Tail shocks & Size of the shock & $\begin{array}{l}\text { - Contagion from negative } \\
\text { funding gaps (linked to macro } \\
\text { stress test) leading to: (i) fire } \\
\text { sales of assets; (ii) rising funding } \\
\text { costs; and (iii) partial closure of } \\
\text { capital markets under a Global } \\
\text { Funding Scenario replicating } \\
\text { post-Lehman funding strains. }\end{array}$ & $\begin{array}{l}\text { - } 5 \% \text { quantile of the conditional } \\
\text { loss distribution. } \\
\text { - Robustness checks applied to } \\
1 \% \text { and } 2.5 \% \text { of the conditional } \\
\text { loss distribution. }\end{array}$ \\
\hline $\begin{array}{l}\text { 4. Reporting } \\
\text { Format for } \\
\text { Results }\end{array}$ & $\begin{array}{l}\text { Output } \\
\text { presentation }\end{array}$ & $\begin{array}{l}\text { - Capital shortfall, system wide. } \\
\text { - Impact on regulatory capital } \\
\text { ratios. }\end{array}$ & $\begin{array}{l}\text { - Contribution to systemic risk. } \\
\text { - Vulnerability to systemic risk. } \\
\text { - Effect of financial state variables } \\
\text { on tail inter-dependence. } \\
\text { - Distribution of results for (i) a } \\
\text { European banking system, and (ii) } \\
\text { a CESEE banking system peer } \\
\text { group. }\end{array}$ \\
\hline
\end{tabular}




\section{Appendix IV. Risks to the Financial Sector from Repayment Vehicles}

\section{Repayment vehicle loan (RPV) exposures continue to pose a challenge to the Austrian} banking system. In the third quarter of 2012, 11.2 percent of net loans to the private sector (mainly to households) were based on repayment vehicles (Figure 22). During the life of an RPV loan, the borrower makes regular payments towards an investment fund or other repayment vehicle to generate funds to pay back the loan principal at maturity. This exposes the borrower to the risks of capital market underperformance and adverse exchange rate developments (as the majority of these loans are denominated in foreign currencies). Funding gaps could arise as a result. The total funding gap of RPV loans was estimated to be about $€ 5.5$ billion (or 18.2 percent of the total loan amount) as of September 2012, with mutual funds-based life insurance products as the main contributors (Table 7). ${ }^{35}$

The short-term risk of RPV loans to the financial sector in Austria, however, is mitigated by several factors. Almost 80 percent of FC bullet loans will mature after 2020. RPV loans are often over-collateralized, thus providing a substantial buffer against adverse market developments. As noted, Austrian household indebtedness is low compared to other advanced countries. Based on OeNB estimates, the share of vulnerable households (with negative financial margins) would remain below 10 percent under a scenario of a 5 percent appreciation of the CHF or a 3 percentage point decrease in RPVs yields. Austrian banks have refrained from issuing new FCLs and RPVs amid tightened regulatory standards and put in place stronger risk management practices for RPVs.

FSAP sensitivity analyses suggest that RPV-related risks are manageable for the Austrian banking system, even in adverse circumstances (Table 8). Adding an additional annual yield shock of 100 yield shock (adverse), and 200 yield shock (severe) across market sensitive product categories to current funding gaps over the remaining maturity of the RPVs, the maximum funding gap would increase from an accumulated $€ 4.2$ billion over the life of the loan to $€ 6.3$ billion (an estimated annual increase of $€ 159 \mathrm{mn}$ ). When combining capital market shocks with adverse foreign exchange developments (13 percent CHF appreciation, equivalent to 1.5 standard deviations), the accumulated funding gap would rise to $€ 8.6$ billion (equivalent to an annual increase of $€ 332 \mathrm{mn}$ ).

${ }^{35}$ This is consistent with the most recent OeNB survey on this issue, showing $€ 5.3$ billion funding gap in mid-2011. 
Figure 22. Austria: Structure of Product Categories of RPVs

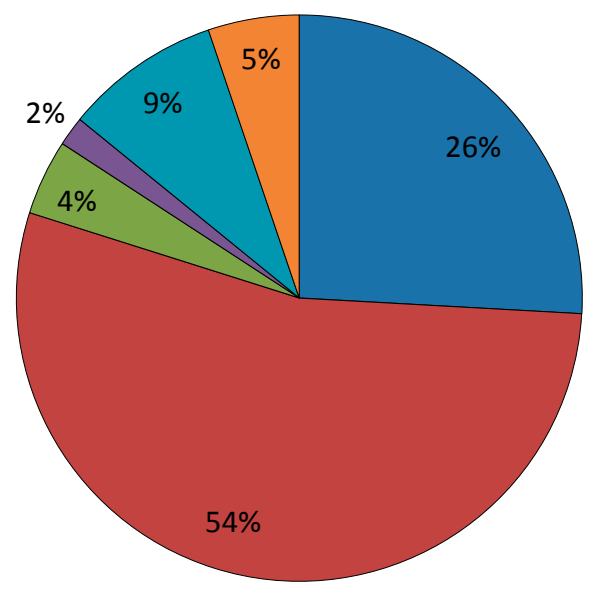

Classic life insurance

Mutual funds-based life insurance

Equity funds

Fixed income funds

Balanced funds

Other instruments

Source: OeNB.

Table 7. Breakdown of RPV's Funding Gap by Product Category

\begin{tabular}{lrrrr}
\hline Sep 2012 estimates, all currences, & Projected & Outstanding & \multicolumn{1}{c}{ Shortfall } & Funding gap \\
\hline Classic life insurance & 6,703 & 7,770 & 1,067 & $13.7 \%$ \\
Mutual funds-based life insurance & 12,812 & 16,218 & 3,406 & $21.0 \%$ \\
Equity funds & 1,084 & 1,299 & 215 & $16.6 \%$ \\
Fixed income funds & 433 & 502 & 69 & $13.8 \%$ \\
Balanced funds & 2,292 & 2,679 & 386 & $14.4 \%$ \\
Other instruments & 1,223 & 1,557 & 335 & $21.5 \%$ \\
\hline Estimated Total & 24,546 & 30,025 & 5,479 & 18.26 \\
\hline
\end{tabular}

Source: OeNB and IMF staff estimates. 


\section{Table 8. Stress Test for RPV Yield and CHF Shock by Product Category}

\begin{tabular}{|c|c|c|c|c|c|c|c|c|}
\hline & \multicolumn{2}{|c|}{ Outstanding Debt } & \multicolumn{6}{|c|}{ Projected Funding Gap (yield and FX shock) } \\
\hline & \multirow[t]{2}{*}{ Baseline } & \multirow[t]{2}{*}{$1.5 \mathrm{SD}$ CHF } & \multicolumn{3}{|c|}{ (in million euros) } & \multicolumn{3}{|c|}{ (in percent) } \\
\hline & & & Baseline & $\begin{array}{l}\text { Adverse } \\
\text { (100 bps) }\end{array}$ & $\begin{array}{c}\text { Severe } \\
\text { (200 bps) }\end{array}$ & Baseline & Adverse & Severe \\
\hline Equity funds & 1,254 & 1,388 & 342 & 405 & 464 & $24.6 \%$ & $29.2 \%$ & $33.4 \%$ \\
\hline Fixed income funds & 485 & 510 & 93 & 119 & 143 & $18.2 \%$ & $23.3 \%$ & $28.0 \%$ \\
\hline Balanced funds & 2,586 & 2,782 & 569 & 706 & 833 & $20.5 \%$ & $25.4 \%$ & $30.0 \%$ \\
\hline Mutual funds-based life insurance & 15,655 & 17,386 & 5,019 & 5,794 & 6,514 & $28.9 \%$ & $33.3 \%$ & $37.5 \%$ \\
\hline Other instruments & 1,503 & 1,663 & 483 & 556 & 624 & $29.0 \%$ & $33.4 \%$ & $37.5 \%$ \\
\hline Total market sensitive & 21,483 & 23,730 & 6,506 & 7,580 & 8,578 & $27.4 \%$ & $31.9 \%$ & $36.1 \%$ \\
\hline Total RPVs & 28,983 & & & & & & & \\
\hline
\end{tabular}

Source: OeNB survey (June 2011) and IMF staff estimates (December 2012).

Note: ${ }^{1 /}$ 50th percentile of daily annual returns over Jan 2005 through Dec 2012 of the following proxy instruments: equity funds (Eurostoxx 50 Equity Index, fixed income funds (JPM euro EMBI global Europe), balanced funds (JPMorgan Investment Funds-

Global Balanced Fund in EUR), mutual funds-based life insurance (Franklin Mutual Series Fund Inc.--Mutual European Fund), other instruments (average yield of the above instruments).

${ }^{2 /}$ The analysis assumes average residual maturity of 13 years drawing from Figure 31 (September 2012).

${ }^{3 /}$ A foreign exchange appreciation increases outstanding debt at maturity as a function of CHF denominated debt across product categories. 


\section{Annex I. Report on the Observance of Standards and codes- Basel Core Principles-Summary Assessment}

1. This assessment was conducted during February 18-25 and April 3-18, 2013 by Arnoud Vossen (Central Bank of the Netherlands), Michael Deasy (Consultant) and Diane Marie Mendoza (IMF). The assessors would like to note their deep appreciation of the full cooperation and courtesy they received from the Austrian authorities and private sector representatives. The grading for each Principle is based on the essential criteria (EC); additional criteria are commented upon but are not reflected in the grading.

\section{A. Supervision Overview of the Institutional Setting and Market Structure}

2. Financial intermediation in Austria is dominated by the banking sector. CIs cover approximately 80 percent of financial market intermediation. The Austrian banking sector is characterized by a large number of CIs, with 822 registered CIs as of mid-2012, mostly due to the prominent role of the decentralized sectors, i.e., local cooperative banks. In June 2012, consolidated total assets of the Austrian banking sector amounted to $€ 1,189$ billion or about 350 percent of GDP, which is large by international comparison.

3. The banking system is characterized by extensive cross-border operations, especially in the CESEE region. Partly due to historical links in the region, Austrian banks expanded through an extensive network of local subsidiaries. CESEE activities have been more profitable than domestic activities, contributing to about 50 percent of total profits in the recent period, while representing less than one-quarter of total bank assets. Within CESEE countries, Austrian banks have market shares above one-third in the Czech Republic, Croatia, Romania, Slovakia and Bosnia. Austrian is also a host country for foreign banking groups, which represent more than 20 percent of total domestic bank assets.

4. The tasks of the supervisory system are governed by a range of separate laws. These include the Financial Market Authority Act, the National Bank Act, the Banking Act, the Insurance Supervision Act, the Pension Funds Act, the Stock Exchange Act, the Investment Fund Act, the Provision of Payment Act, and the Capital Market Act.

\section{Austria's supervisory approach is characterized by a dual supervisory system.}

Responsibilities are shared between the Financial Market Authority (FMA) and the Central Bank of Austria (OeNB). Specifically:

- The FMA, as the integrated supervisory institution, is responsible for supervising all significant providers of financial services and functions. It supervises credit institutions (CIs), financial institutions (e.g., payments institutions, e-money institutions), insurance undertakings, pension companies, corporate provision funds, investment firms and investment service providers, investment funds, financial conglomerates and stock exchanges. 
- The OeNB is responsible for the execution of all on-site inspections on the basis of inspection orders issued by the FMA. The OeNB also has the right to request audits or the expansion of inspection orders. Furthermore, the OeNB is responsible for off-site analysis taking into account all the data which CIs are obliged to report. The FMA issues all the necessary rulings and considers all legal questions in the field of banking supervision. A key element of this cooperation is the sharing of all supervisory-related data held by both institutions in a single database. The OeNB is solely responsible for the oversight of payment systems in Austria.

\section{B. Precondition for Effective Supervision}

6. Macroeconomic environment. The sustainability of public finances and growth-promoting policies have contributed to the generally healthy state of the banking industry in Austria. Due to several policy measures, the Austrian housing market is characterized by a high share of rented accommodation thereby reducing price volatility in the real estate market.

7. Legal environment. Austria has a highly developed system of business laws including corporate, bankruptcy, contract, consumer protection, and private property laws. Its legal and accounting regime are in keeping with an advanced economy.

8. Financial stability framework. The OeNB's Financial Markets Analysis and Surveillance Division, as part of the Financial Stability and Bank Inspections Department, is responsible for identifying, monitoring and assessing the build-up of systemic risk. This would include stress testing on a number of levels. Also, the FMA and the OeNB participate actively in the bodies of the European System of Financial Supervision.

9. Recent changes. In anticipation of the adoption of EU Commission's proposals regarding a framework for the recovery and resolution of banks and investment firms, Austria has recently passed a law including additional national measures and instruments for early intervention; however provisions for bank resolution are currently postponed for the implementation of the pending EUBank Recovery and Resolution Directive. This national law requires credit institutions to set up recovery and resolution plans and provides the FMA with a set of early intervention tools.

\section{Main Findings}

Objectives, powers, independence, accountability, and cooperation (CPs 1-3)

10. Clear responsibilities, objectives and powers are attributed to the FMA as the financial sector supervisor in Austria. The FMA is the only competent authority for regulatory supervision in Austria. The OeNB is assigned non-regulatory banking supervision tasks and powers. A key element of the cooperation between the FMA and the OeNB is the sharing of all supervisory-related data held by both institutions in a single database. In general, the existing supervisory approach, techniques and tools, and reporting systems are adequate.

11. There are adequate resources to undertake effective supervision, including skilled professionals to undertake the various supervisory tasks. 
12. Governance improvements are needed in a number of areas related to FMA's independence and accountability. In addition, the FMA has only limited authority to issue legallybinding rules, and the current liability framework does not sufficiently protect the FMA and its staff.

\section{Ownership, licensing and structure (CPs 4-7)}

13. The FMA is the licensing authority, and permissible activities of institutions that are licensed and subject to supervision are clearly defined. The Austrian legislation provides for a clear definition of the term 'bank' and clear processes for handling new licenses.

14. The FMA performs a fit and proper test on all directors that comprise the management board irrespective of the balance sheet and on the chairman of the supervisory board for CIs with total assets exceeding $\mathbf{€ 7 5 0}$ million. The FMA does not have the legal powers to undertake a fit and proper test on any other senior employee of the $\mathrm{CI}$, on members of the supervisory board, or on the chairman of the supervisory board in CIs with total assets below $€ 750$ million. Additionally, the supervisor does not have the power to require changes in the composition of the supervisory board if members of the supervisory board are not fulfilling their duties. In case the chairman of the supervisory board would no longer qualify, the FMA could address measures towards the CI, not directly towards the persons concerned. The FMA would then order the CI to have the chair of the supervisory board removed. In second instance, the FMA could prevent senior management from taken decisions that need approval of the supervisory board and/or the FMA could make its order towards the $\mathrm{CI}$ about the chairman of its supervisory board public. Legislative changes are being implemented to provide the FMA with more extensive powers with regard to fit and proper tests.

15. New entrants are subject to all relevant regulations as of the time of their licensing, but no specific supervisory regime applies to them. A more hands-on regime for new entrants in their first years of establishment might be warranted.

16. The FMA has adequate powers with respect to the transfer of significant ownership, although there is no explicit legal requirement for banks to notify the FMA as soon as they become aware of any material information which may negatively affect the suitability of a major shareholder or a party that has a controlling interest.

17. Concerning major acquisitions or investments by a bank, there is no prior approval process for investments by an Austrian bank in non-bank financial institutions outside the EEA or for non-bank non-financial institutions inside or outside the EEA. Also no prior approval is necessary for setting up a credit institution in a third country when this would be done by means of a Greenfield operation.

Methods of ongoing banking supervision (CPs 8-10)

18. The FMA develops and maintains a forward-looking assessment of individual banks' risk profiles that is proportionate to their systemic importance. Amongst others, it uses an extensive 
early warning system for identifying potential risks and has adequate mechanisms to address them under on-going supervision.

19. The obligation to draw up recovery and resolution plans currently exists only for the three largest internationally active banking groups. On January 1, 2014 the Bank Reorganisation Act (Federal Law Gazette no. I 160/2013) enters into force which will require credit institutions to set up recovery and resolution plans. Also, the FMA at the moment does not have a clear framework for handling banks in times of stress, such that the necessary decisions to require recovery and resolution actions are made in a timely manner, notwithstanding the extra powers the FMA has concerning corrective action for cases of danger to fulfillment of the bank's obligations vis-à-vis its creditors.

20. An appropriate range of supervisory tools and techniques is used in on- and off-site supervision, including a state-of-the-art supervisory reporting system. OeNB and FMA jointly define an audit plan for each upcoming year. A multi-year planning process may be considered, since specific multi-year planning cycles exist for certain credit institutions.

\section{Corrective and sanctioning powers of supervisors (CP11)}

\section{Corrective supervisory powers rely heavily on extra capital requirements and on} penalties at present. The FMA does not have the powers to directly intervene at an early stage by issuing an order to remedy a deficiency, for instance regarding a bank's risk management systems, or by issuing an order that would prohibit, limit or set other conditions on the business activities or exposures of the bank in question, when risks are building up or are not properly captured. Also, only natural persons can be penalized for administrative and criminal offences, not the institution. It is understood that with the implementation of the CRD IV Directive, sanctioning powers will also be extended to legal persons.

\section{Consolidated and cross-border banking supervision (CPs 12-13)}

22. While the current legal and regulatory framework generally supports adequate crossborder supervisory cooperation, legal constraints hamper effective information exchange with some countries. Many Austrian banks operate cross-borders, and an adequate framework for cooperation with other authorities is implemented, including an adequate protection of confidential information. In particular, for the largest cross-border operating banks, fully-fledged colleges are in place, and Austria has played a leading role in this respect. However, it has not been possible to conclude agreements on the exchange of confidential supervisory information with some non-EEA host supervisors, which limits effective supervisory cooperation for the banking groups concerned.

\section{Corporate governance (CP 14)}

23. The internal auditor reports directly to the board of directors, and audit results must also be reported quarterly to the chairman of the supervisory committee. In keeping with best 
international practice, it would be more appropriate for the internal auditor to report directly to the chairman of the supervisory committee and have full access to the chairman on an on-going basis.

Prudential requirements, regulatory framework, accounting and disclosure (CPs 15-29)

24. There is no explicit requirement for larger and more complex banks to have a dedicated risk management unit overseen by a Chief Risk Officer or equivalent function. The FMA and OeNB expect such arrangements to exist and, as far as can be ascertained, this is indeed the case. To eliminate uncertainty, however, it is proposed that the FMA introduce such a requirement explicitly.

25. Austria has applied Basel II through the adoption of the EU CRD. It will implement Basel III through the adoption of CRD IV/CRR1 later this year. The estimated additional capital required by the Austrian Bank Sector to meet Basel III requirements was $€ 3-8$ billion. (The difference relates to the uncertainty surrounding Tier II capital.) The three largest banking groups (Erste Group Bank, Raiffeisen Zentralbank and Unicredit Bank Austria) already meet the 7 percent threshold for Common Equity Tier 1.

26. In 2008, the Austrian Government, and to a much lesser extent the private sector, invested a total of $€ \mathbf{5 . 2}$ billion by way of participation shares in a number of Austrian banks. This capital, which under a special transitional provision in CRD IV qualifies as Tier I capital until 2017, is due for repayment at end 2017.

27. There are no specific provisions requiring banks to make credit decisions free of conflicts of interest and on an arm's length basis.

28. The level of NPLs has remained more or less stable within Austria over the last number of years, at less than 5 percent. That of CESEE, however, has risen by 5 percentage points over the last 4 years and now stands at 16 percent, giving an overall consolidated figure of about 9 percent for Austrian banks.

29. Of particular concern in Austria is FCL, both domestically (largely Swiss Francs) and through foreign subsidiaries (largely Euros), which stand at more than $€ 50$ billion. No new FCLs are now being extended. These loans (many mortgages) were structured as investment vehicles, the proceeds of which on maturity were intended to clear the loan in one bullet payment. However, the value of these investments is falling short of their anticipated value at inception and the proceeds may not be sufficient to clear the loan on maturity (as well as possibly incurring an FX loss). NPL levels tend to be higher for these loans. For instance, in the CESEE region total NPLs stood at 15.9 percent at end June 2012 whereas the figure for FX loans stood at 19.7 percent. Since the first publication of FMA minimum standards on FCL in 2003 the FMA has taken several measures such as the issuance of a recommendation to stop immediately FC-lending to private households in October 2008 or the publication of new encompassing minimum standards on FCL and loans with repayment vehicles (LRV) in January 2013. The goal of these new minimum standards was a unification of the existing standards, the full implementation of ESRB recommendations (September 2011) on national 
scale and the incorporation of past supervisory experience. As key figures are showing regulatory action was effective. From October 2008 to March 2013 the total FCL volume to private households declined by 35 percent ( $f x$-adj.) or $€ 16.3$ billion. The $F C L$ share (priv. households) decreased to 23.1 percent in Q1 2013 (Q4 200831.2 percent).

30. There are a number of deficiencies in relation to rules and regulations dealing with transactions with related parties. These include the absence of an explicit requirement to the effect that transactions with related parties must not be undertaken on more favourable terms than corresponding transactions with non-related counterparties.

\section{Austria has detailed requirements relating to market, interest rate and operational} risks. Compliance with these requirements is monitored closely by the authorities.

\section{Austrian banks have a stable funding profile relying heavily on retail and corporate} deposits. Loan to deposit ratios both within Austria and including foreign subsidiaries are comparatively low and have been decreasing in recent years. One possible liquidity problem facing Austrian banks relates to their FCL exposures which are mostly long term (mortgages). The FMA monitors these currency risk exposure, and banks have swap arrangements in place to deal with this risk.

33. There is a very restrictive requirement for Austrian banks to have a compliance function related to securities services. There is no general requirement for banks to have a total business-wide compliance function.

34. Austrian local GAAP are based on EU regulation. All Austrian banks must prepare their unconsolidated financial statements on this basis. In relation to the role of the external auditor, the supervisor has no power to access the auditors' internal working papers due to the latter's professional confidentiality requirements.

\section{Austria was criticized on a number of fronts during the 2008 FATF Mutual Evaluation}

Assessment. That Mutual Evaluation Assessment was followed up by two follow-up reports (in 2011 and 2012). A third follow-up report is scheduled for later in 2013. According to the FMA, there is just one minor issue outstanding relating to the definition of terrorist financing. Accordingly, Austria has asked of FATF that this be the last follow-up meeting. 
Annex Table 1. Recommendations to Improve Observance of BCPs

\begin{tabular}{|c|c|}
\hline Reference Principle & Recommended Actions \\
\hline $\begin{array}{l}\text { 2. Independence, } \\
\text { accountability, resourcing } \\
\text { and legal protection for } \\
\text { supervisors }\end{array}$ & $\begin{array}{l}\text { On independence: } \\
\text { Delete the confirmation by the supervisory board of the second level } \\
\text { staff, just below the level of the supervisory board. } \\
\text { Discontinue the presence of the industry in the Supervisory Board of } \\
\text { the FMA, by creating a separate industry forum or panel not linked to the } \\
\text { supervisory board } \\
\text { - Consider a staggered scheme for the starting and ending of the terms } \\
\text { of the supervisory board members. } \\
\text { Introduce the legal obligation to publicly disclose the reasons for the } \\
\text { dismissal of a member of the Executive Board. } \\
\text { Clarify at a minimum ex ante based upon which considerations and } \\
\text { criteria the MoF could make use of Article } 16 \text { para } 4 \text {. } \\
\text { Clarify ex ante that the MoF will always give its consent on a proposed } \\
\text { FMA regulation, in case this regulation would fall within the scope of its } \\
\text { mandate to set up such a regulation } \\
\text { Consider a more limited and focused right for the MoF to receive } \\
\text { information in the context of its oversight of the operations of the FMA } \\
\text { Clarify that considering the national economic interest might never } \\
\text { impede FMA's supervisory considerations and might consequently not in any } \\
\text { way weaken its operational independence } \\
\text { On governance: } \\
\text { - } \\
\text { - } \\
\text { On lopics that it considers relevant. } \\
\text { scrutinized than prudential measures }\end{array}$ \\
\hline 5. Licensing criteria & $\begin{array}{l}\text { Introduce fit and proper criteria for all members of supervisory boards. } \\
\text { Provide the supervisor with the legal basis and powers to require changes in } \\
\text { the composition of the Supervisory Board } \\
\text { Implement a more hands-on regime for new entrants in their first years of }\end{array}$ \\
\hline
\end{tabular}




\begin{tabular}{|c|c|}
\hline & $\begin{array}{l}\text { establishment, which is used to monitor the progress of new entrants in } \\
\text { meeting their business and strategic goals, and to determine that supervisory } \\
\text { requirements are met. }\end{array}$ \\
\hline $\begin{array}{l}\text { 6. Transfer of significant } \\
\text { ownership }\end{array}$ & $\begin{array}{l}\text { Introduce an explicit notification requirement for CI's to notify to the } \\
\text { supervisor as soon as they become aware of any material information which } \\
\text { may negatively affect the suitability of a major shareholder or a party that has } \\
\text { a controlling interest. }\end{array}$ \\
\hline 7. Major acquisitions & $\begin{array}{l}\text { Provide the FMA with the necessary powers that will enable it to pre-approve } \\
\text { investments or acquisitions in non-bank financial institutions as well as in non- } \\
\text { bank non-financial institutions, given the risks involved. } \\
\text { Clarify or revise the current Banking Act in such a way that Greenfield } \\
\text { operations when undertaken via setting up a subsidiary in another country, } \\
\text { would also need pre-approval by the FMA. }\end{array}$ \\
\hline 8. Supervisory approach & $\begin{array}{l}\text { Consider introducing a specific unit or functionary responsible for the further } \\
\text { development of the supervisory approach and methods and for the quality } \\
\text { control of the supervisory processes. } \\
\text { Provide the FMA the powers to require CI's to set up recovery and resolution } \\
\text { plans and to assess thereon the bank's resolvability, and to require banks to } \\
\text { adopt appropriate measure in case barriers for an orderly resolution would be } \\
\text { identified and that it will be provided with a clear framework or process for } \\
\text { handling CI's in time of stress, such that any decisions to require or undertake } \\
\text { recover or resolution actions are made in a timely manner, in line with } \\
\text { international best practices. }\end{array}$ \\
\hline $\begin{array}{l}\text { 9. Supervisory techniques } \\
\text { and tools }\end{array}$ & $\begin{array}{l}\text { Consider using a supervisory planning process beyond the time frame of one } \\
\text { year, which also facilitates a multi-year audit plan. (See Recommendation } \\
\text { under CP2). } \\
\text { Consider to implement a periodic independent review on the supervisory } \\
\text { processes undertaken by the FMA and OeNB. }\end{array}$ \\
\hline 10. Supervisory reporting & $\begin{array}{l}\text { Implement the current draft Article } 4 \mathrm{No.53} \text { of the CRR as soon as possible, } \\
\text { concerning the changeover for prudential purpose of national GAAP to IFRS. }\end{array}$ \\
\hline $\begin{array}{l}\text { 11. Corrective and } \\
\text { sanctioning powers of } \\
\text { supervisors }\end{array}$ & $\begin{array}{l}\text { Provide the supervisor with the powers to directly intervene at an early stage } \\
\text { by issuing an order to remedy a deficiency in for instance the CI's risk } \\
\text { management systems or by issuing an order that would prohibit, limit, or set } \\
\text { conditions on the business activities or exposures of a CI, when risks are } \\
\text { building up or are not properly captured by the CI. } \\
\text { Consider extending the FMA's power in applying penalties to the CIs in } \\
\text { addition to natural persons, which might also impact the maximum level of } \\
\text { these penalties. } \\
\text { Provide the FMA with the power to directly take a measure against a person } \\
\text { (more specifically the director or member or chairman of the supervisory }\end{array}$ \\
\hline
\end{tabular}




\begin{tabular}{|c|c|}
\hline & board of the CI) which is not deemed fit and proper. \\
\hline $\begin{array}{l}\text { 13. Home-host } \\
\text { relationships }\end{array}$ & $\begin{array}{l}\text { Evaluate the measures that have been taken to effectively exercise supervision } \\
\text { in the absence of such arrangements, amongst others in the context of the } \\
\text { effective handling of a crisis situation. } \\
\text { Assess in the context of the supervisory college, the recovery and resolution } \\
\text { plans that will be developed by the CI's and assessed by the supervisory } \\
\text { authority as a result of the changes to the law in Austria, in conjunction with } \\
\text { the host authorities concerned. }\end{array}$ \\
\hline 14. Corporate governance & $\begin{array}{l}\text { Require the internal auditor to report to the supervisory board in the first } \\
\text { instance. }\end{array}$ \\
\hline $\begin{array}{l}\text { 15. Risk management } \\
\text { process }\end{array}$ & $\begin{array}{l}\text { Introduce explicit requirements for all larger and complex banks to have a } \\
\text { dedicated risk management unit overseen by a Chief Risk Officer or equivalent } \\
\text { function. }\end{array}$ \\
\hline 17. Credit risk & $\begin{array}{l}\text { Introduce specific provisions requiring banks to make credit decisions free of } \\
\text { conflicts of interest and on an arm's length basis. }\end{array}$ \\
\hline $\begin{array}{l}\text { 18. Problem assets, } \\
\text { provisions, and reserves }\end{array}$ & $\begin{array}{l}\text { Ensure that the supervisor has appropriately trained staff who are familiar with } \\
\text { local laws and regulations in the CESEE region, particularly in the area of } \\
\text { collateral valuations (e.g., real estate). }\end{array}$ \\
\hline $\begin{array}{l}\text { 20. Transactions with } \\
\text { related parties }\end{array}$ & $\begin{array}{l}\text { There are quite a number of deficiencies in the area of related party lending, } \\
\text { although in certain areas there are indirect mitigants. It is recommended that } \\
\text { the Austrian authorities re-examine the whole area of related party } \\
\text { regulations. They should also consider introducing new, more restrictive, limits } \\
\text { on such lending than that which exists currently. }\end{array}$ \\
\hline $\begin{array}{l}\text { 26. Internal control and } \\
\text { audit }\end{array}$ & $\begin{array}{l}\text { Introduce an explicit requirement for banks to have a total business wide } \\
\text { compliance function (as opposed to the current restrictive securities-related } \\
\text { one). } \\
\text { Consider lowering the threshold for the need for banks to establish an audit } \\
\text { committee from } € 1 \text { billion to, say, } € 500,000 \text { in total assets. }\end{array}$ \\
\hline $\begin{array}{l}\text { 27. Financial reporting } \\
\text { and external audit }\end{array}$ & $\begin{array}{l}\text { Consider allowing banks to prepare their non-consolidated financial } \\
\text { statements using IFRS. } \\
\text { It is recommended that the FMA be given the power to access external } \\
\text { auditors' working papers, where necessary. }\end{array}$ \\
\hline $\begin{array}{l}\text { 28. Disclosure and } \\
\text { transparency }\end{array}$ & $\begin{array}{l}\text { Consider developing specific indicators for publication that provide risk } \\
\text { information from one to the other year for individual } \mathrm{CI} \text {. }\end{array}$ \\
\hline
\end{tabular}




\section{Authorities' Response}

The Austrian authorities, i.e., the Ministry of Finance (hereinafter "MoF"), the Austrian Financial Market Authority (hereinafter "FMA") and the OeNB (hereinafter "OeNB") appreciated the good discussions and the extensive analysis contained in this report. Nevertheless, it seems necessary to comment on the following issues:

\section{CP 2: Independence, accountability, resourcing and legal protection for supervisors}

On independence:

For constitutional reasons (accountability and governance) even independent bodies such as the FMA are subject to legal supervision. This legal supervision is limited on whether the FMA carries out their business within the legal framework. The legal supervision does not interfere with the operational work of the FMA as it is limited on cases of wrongful action or omission. Section 16 FMABG deals with this legal supervision and has to be read together with section 1 FMABG. Considering the compliance with the essential and additional criteria of BCP 2 relating to the operational independence of the FMA and the already very limited form of legal supervision stipulated in section 16 FMABG we can't agree to amending Article 16 FMABG in the proposed way. As the assessors noted, the FMA has been commissioned only once with an on-site examination. The consent of the MoF on regulations of the FMA is limited to a small number of cases. Article 16 para. 1 allows requests for information only to ensure that the FMA fulfills its statutory tasks and does not violate laws and regulations or overstep its scope of duties. As regards the participation of representatives of the industry in the supervisory board it should be noted that they participate in the meetings only on specific, cost-related topics, do not receive the full set of documents and have no voting rights. This way the effect is de facto the same as with a special panel, but less time consuming.

As regards the appointment of members of the supervisory board of the FMA, it is the general approach for all corporations that members are appointed for the same period of office. Thus, there is no particularity or difference with regard to the appointments of supervisory board members of the FMA compared with the relevant procedures of any other Austrian corporation.

Possible reasons for dismissals of members of the Executive Board of the FMA are clearly stipulated in Article 7 para. 3 FMABG. In case of a dismissal conducted by the MoF, information on the case is subject to the general obligation of all governmental entities to give information according to the "Auskunftspflichtgesetz" (Duty of Information Act) as well as the case is subject to the Parliament's information right.

On governance:

The recommendation concerning the reporting line of the Internal Audit does not adequately reflect the two-tier governance system prevailing in Austria. Contrary to the one-tier governance model in which one body (usually the « Board ») exercises both executive and supervisory functions and is 
composed of executive and non-executive members, the task of the supervisory board within a twotier system is limited to monitoring and overseeing the performance of the executive board including the implementation of the company's strategic objectives. The day-to-day management of the organisation is the sole responsibility of the executive board which has the power to issue binding instructions in relation to (all) managers and employees. This is mirrored in the reporting line (first executive board, then supervisory board). The audit function should thus in principle remain as a tool of the executive board. Furthermore, the Internal Audit must report quarterly on significant findings to the chair of the supervisory board. Direct and constant access of the Internal Audit to the supervisory board does not fit within the two-tier governance system as applicable in Austria.

On legal protection:

Currently, the arrangements for protection of employees of the FMA "acting in good faith" are comprehensive. The FMA staff cannot be held directly (personally) liable by third parties. Damages must be claimed against the Republic of Austria. If a court rules that the Republic is to be held liable, the Republic may (but need not) decide to claim compensation from liable staff, but with major limitations. According to the "Amtshaftungsgesetz-AHG," no compensation can be claimed by the Republic for minor or ordinary negligence, and even in cases of gross negligence, the deciding court can reduce damages to be paid by the employees. In situations which could cause compensation claims against employees of the FMA but which do not fall within the scope of the "Amtshaftungsgesetz", the employees of the FMA are protected by the rules of the "Organhaftpflichtgesetz-OrgHG" or the "Dienstnehmerhaftpflichtgesetz-DNHG." In such cases, no compensation can be claimed for minor negligence and even in cases of ordinary negligence, the deciding court can reduce or completely release employees from paying damages. In general, any court ruling to pay damages must not threaten the livelihood of the employee. For the very unlikely case that an employee is sued for damages in practice, the FMA has to grant adequate legal protection to its employees according to Article 14 para. 3 FMABG. However, we share the view expressed by the IMF that with the introduction of the SSM, in particular when the FMA's bodies and staff act on behalf of the ECB, complementary arrangements in the public liability framework will need to be considered. Similarly, the forthcoming resolution powers may raise new issues regarding the effectiveness of the public liability framework to ensure legal protection of the FMA's bodies and staff, which also will need to be considered.

\section{CP 5: Licensing criteria}

The recommended action to introduce fit and proper criteria for all members of supervisory boards will be fulfilled by May 22, 2013, when the EBA Guidelines on the Assessment of the Suitability of the Members of the Management body and Key Function Holders (EBA/GL/2012/06, "F\&P-GL") enter into force. According to Article 69 para. 5 Banking Act these Guidelines are directly applicable by the FMA.

The F\&P-GL apply to competent authorities and CIs. Financial and mixed financial holding companies are also included in the scope of the Guidelines, because they have significant influence 
on their CIs. In order to inform the public (most notably CIs and their boards members) about the new requirements and supervisory approach and to ultimately ensure maximal compliance by CIs the FMA published a Circular setting out the criteria and minimum requirements for assessing the fitness and propriety of members of the management body and key function holders (Rundschreiben zur Eignungsprüfung von Geschäftsleitern, Aufsichtsratsmitgliedern und Inhabern von Schlüsselfunktionen (Fit \& Proper-Rundschreiben) as of May 2013). (Please refer to CP 5 EC 7 for further details).

According to the F\&P-GL "key function holders" are those staff members whose positions give them significant influence over the direction of the $\mathrm{CI}$, but who are not members of the management body. Key function holders might include heads of significant business lines, EEA branches, third countries subsidiaries, support and internal control functions. The fit and proper assessment has to be undertaken on newly appointed members of the management body, supervisory board and key function holders as well as on ongoing review. In this context "key functions holders" are considered as equivalent to "senior employees."

Already now, the FMA monitors the suitability of the internal auditor of the $\mathrm{CI}$ according to Article 42 paras. 1 and 2 Banking Act and-as appropriate - verifies that the persons in question have the required expertise and experience in banking. According to Article 42 para. 1 Banking Act the duties of the internal audit must not be entrusted to persons who lack the required expertise and experience in banking. The internal auditor has to be notified to the FMA and all documents that prove the required expertise and experience have to be presented, too. The FMA has the power to require the exclusion of an inappropriate internal auditor by an administrative ruling according to Article 70 para. 4 Banking Act.

The FMA has to make every effort to comply with the F\&P-GL, which set out prerequisite conditions on the assessment of the suitability of the members of the supervisory board and will not accept any breach of these requirements. The FMA is currently incorporating the F\&P-GL into its supervisory practices and expanding the scope of fit and proper assessments to all members of the supervisory board in risked based manner. Whenever a supervisory board member is not considered suitable, the FMA will order the $\mathrm{CI}$ to reestablish lawful conditions by having a supervisory board in line with the legal requirements according to Article 70 para. 4 Banking Act.

Upon an amendment of the respective articles in the Banking Act as of January 1, 2014, the FMA will have the direct power in the Banking Act to ensure a greater scope for action following a breach and to ultimately require changes in the composition of the supervisory board if members of the supervisory board are not fulfilling their duties relating to these requirements.

It is correct that no specific supervisory regime applies to new entrants, as the new entrants have to fulfill all relevant regulations as of the time of their licensing.

However, in the course of application for a license (according to Articles 4-6 Banking Act) new entrants are obliged to present the business plan, budget calculation and all other processes, 
systems, models etc. which are necessary to run the applied banking business. The license will only be granted if the analysed plans, processes, models, etc. (in accordance with the OeNB) are considered as plausible and effective. Considerable differences between the budget calculation in the business plan presented with the application and the results later-on would be detected through the monthly/quarterly and annual reports to be submitted by the CI to the OeNB. Adequate measures would then be taken immediately by the FMA, starting within the framework of routine management discussions. Furthermore, the FMA takes new entrants into due consideration, when establishing its yearly planning (together with the OeNB) for on-site inspections of CIs, so that such new entrants are audited in due time after the start of their business activities.

The FMA notes the recommendation to implement a more hands-on regime for new entrants in their first years of establishment to monitor the progress of new entrants in meeting their business and strategic goals, and to determine that supervisory requirements are met. However, the FMA already considers the current procedure regarding new entrants as a hands-on regime.

On the one hand the new entrants are individually monitored in the course of their application for license, as they have to present the business plan, budget calculation and all other processes, systems, models etc which are necessary to run the applied banking business. The license will only be granted if the presented and analysed plans and processes etc are considered as plausible and effective. On the other hand the new entrants are continually monitored after being licensed through the monthly/quarterly and annual reports to be submitted by the CI to the OeNB.

Considerable differences between the budget calculation in the business plan presented with the application and the results later-on would be detected and the adequate measures would then be taken immediately by the FMA, starting within the framework of routine management discussions. Furthermore, the FMA takes new entrants into due consideration, when establishing its yearly planning (together with the OeNB) for on-site inspections of CIs, so that such new entrants are audited in due time after the start of their business activities.

\section{CP 7: Major acquisitions}

It is planned to introduce an obligation for prior approval for setting up a $\mathrm{CI}$ in a third country by means of a greenfield operation by amending the relevant provision in Article 21 Banking Act.

Regarding the recommendation to provide the FMA with additional powers to pre-approve investments or acquisitions in non-bank financial institutions it should be noted that the FMA is already able to prohibit such investments if it is deemed necessary (see also CP 11). Concerning the risks involved with such investments, the Austrian authorities would like to point out that

- The OeNB and the FMA have regular meetings and discussions with the executive board of CIs, which also cover cross-border participations in particular. Additional information on emerging risks in participations may be obtained by the state commissioner, if applicable. 
- An individual acquisition of a non-bank non-financial institution is permitted up to 15 percent of own funds. The total share of such non-bank non-financial activities must not exceed 60 percent of own funds. Any exceeding amount must be fully covered by own funds due to Article 29 Banking Act which is audited regularly by the internal auditor and the bank auditor. An individual acquisition of non-bank non-financial institution must not exceed 25 percent of own funds in any case.

- $\quad$ Furthermore, the risks connected with participations in non-bank financial institutions are monitored by the supervision on a consolidated group level (Article 30 Banking Act).

Hence, there are rules in place to mitigate the risks connected with such investments.

Furthermore, the Austrian authorities would like to point out that of all CP 7's essential criteria only the aspect of prior permission of certain—but not all—types of investments (mainly concerning investments in non-bank non-finance institutions) is not fully covered by legislation.

\section{CP 8: Supervisory approach with respect to recovery and resolution}

The Bank Reorganisation Act has entered into force (Federal Law Gazette I Nr. 160/2013). Accordingly all institutions are obliged to draw up recovery and resolution plans that will be assessed by the FMA. This obligation is subject to the proportionality principle. Furthermore the FMA has a set of early intervention tools at its disposal.

\section{CP 11: Corrective and sanctioning powers of supervisors}

Within the supervision of CIs, it is the main task of the FMA to ensure that the arrangements, processes and mechanisms of credit institutions are comprehensive and proportionate to the nature, scale and complexity of the risks inherent in the credit institutions' business activities. If the FMA concludes that risks stemming from certain activities are not adequately covered, supervisory measures (e.g., the order to cease a certain conduct) will be imposed.

The FMA notes the recommendation to be provided with extra powers to issue an administrative order that would prohibit, limit, or set conditions on the business activities and exposures of a $\mathrm{CI}$, due to a deterioration of its financial position. However, the FMA has already a range of corrective and sanctioning powers at its disposal: Article 70 Banking Act provides the FMA with a broad range of corrective and sanctioning powers if the fulfillment of the CI's obligations to its creditors is jeopardized. As pointed out in EC 6, for instance, in case of a quick deterioration in the financial position of a CI the FMA may issue administrative rulings under threat of penalty as remedial action according to Article 70 para. 2 Banking Act. This administrative ruling may (fully or partly) prohibit the withdrawal of capital and earnings as well as distributions of capital and earnings, appoint an expert supervisor (i.e., government commissioner) who prohibits transactions that are deemed to exacerbate the mentioned jeopardy or-in case that the $\mathrm{CI}$ has been enjoined to refrain from certain or all types of business-allows individual transactions that are deemed to not exacerbate the 
mentioned jeopardy. Further the administrative ruling may (partly) prohibit directors from managing the $\mathrm{CI}$ or (partly) prohibit the continuation of business operations.

Further on, the FMA will be informed of a "problem situation" immediately by the bank auditor (Article 63 para. 3 Banking Act), the state commissioner (Article 76 para. 8 Banking Act), the CI e.g., on circumstances that allow a prudent director to recognize that the ability to fulfill obligations is endangered, on the occurrence of insolvency or of over-indebtedness, any non-compliance in excess of one month with standards prescribed by the Banking Act (Article 73 Banking Act).

Nevertheless, it is planned to further clarify the range of possible supervisory tools of the FMA in more detail, enabling the FMA explicitly by law to restrict or limit the business, operations or network of credit institutions or to request the divestment of activities that pose excessive risk to the soundness of a $\mathrm{CI}$ or to require the reduction of the risk inherent in the activities, products and systems of CIs.

Taking the above into account, the Austrian supervisor has already under the present set of rules the possibility to intervene directly in case of a risk of the fulfillment of the CI's obligation to its creditors by issuing an administrative ruling that would prohibit, limit, or set other conditions on the business activities or exposures. Furthermore, some early intervention measures for the supervisor are provided in the Austrian Bank Reorganisation Act.

\section{CP 13: Home-host relationships}

FMA is fully committed to information exchange and cross border cooperation. Austria is in line with the requirements set by EBA and the European framework on the establishment of supervisory colleges. Therefore the recognition of equivalence of a respective country has to be assessed and determined within these parameters on a European level and be in line with the confidentiality regime of the participating countries.

According to Article 131a Directive (EC) 2006/48 (=CRD) the main requirement to conclude arrangements for the confidential exchange of supervisory information with competent authorities of third countries is that these third country competent authorities are subject to confidentiality requirements that are equivalent to Articles 44 to 52 CRD. Therefore, according to the European framework, the Austrian supervisor must not conclude arrangements on confidential supervisory information exchange with third-country competent authorities not being subject to equivalent confidentiality requirements.

There is no European framework for resolutions plans yet. Ahead of the regulation to come the Austrian supervisor received resolution plans from the three largest CI's accounting for almost half of total bank assets of the Austrian market. The recovery and resolution plans will be part of the discussions within the colleges. 


\section{CP14: Corporate Governance}

There is the legal obligation for the internal audit to report quarterly to the chair of the supervisory board and the audit committee. It has to be stated that an audit committee is obligatory for all banks with a balance sheet exceeding $€ 1$ billion. The committee guarantees a frequent and direct reporting line to the relevant committee of the supervisory board. Please refer also to the Austrian comments with respect to CP 2 on the reporting line of internal audit.

\section{CP 15: Risk management process}

Currently, there is no explicit legal requirement for the appointment of a dedicated risk officer. However, the FMA Minimum Standards for the Credit Business and other Transactions entailing Credit Risks (FMA-MS-K) stipulate a clear functional separation between front office and risk management / back office functions. Also in all other lines of business the supervisory expectations concerning the segregation of duties between risk-taking and risk management units are following the same standards as set out for the area of credit risk. In fact, a dedicated CRO is in place in all larger banks, as well as a strict separation of market/control-functions.

It is planned to introduce an explicit requirement for CIs to have a dedicated risk management function in the course of 2013. The main task of the risk management function, which has to be independent from operational functions, will be to ensure that all material risks are identified, measured and properly reported. Moreover, there will be the obligation for CIs to establish a "risk committee" as a subcommittee of the supervisory board as the Banking Act has been amended accordingly. The risk committee shall advise the executive board on the CI's overall risk strategy and will assist the supervisory board in overseeing the implementation of the risk strategy.

\section{CP 17: Credit Risk}

The Austrian supervisor has set comprehensive rules and regulations regarding credit risk in credit institutions. Regarding credit decisions free of conflict of interest and on an arm's length (EC 5) it needs to be pointed out that even though there is no specific provision requiring banks to make such credit decisions the FMA relies on "Minimum Standards for the Credit Business and other Transactions entailing Counterparty Risks" and other requirements. The detailed assessment of the IMF rightly notes that according to these Minimum Standards "prudent lending practices imply a segregation of duties and the involvement of more than one person when granting a loan.

Depending on the amount of the loan, different hierarchies are involved. This system of involvement of different groups in the lending process (loan officer, risk manager, credit committee, supervisory board, etc.) provides a high level of safety against a possible conflict of interests or pressure from outside parties." However, this aspect is not adequately reflected in the assessment.

\section{CP 18: Problem assets, provisions and reserves}

The setup of the supervisory colleges guarantees mutual exchange with colleagues from the host countries that have broad knowledge of the laws, procedures and specific risks within their home 
jurisdiction. Furthermore, supervisory actions in (CESEE-) host countries may take place in various forms of inspections of host subsidiaries in coordination with the respective supervisory authorities. On-site actions have taken place in several CESEE-countries in the past years, dedicated experience with respect to local laws and regulations as well as risk management issues have been built up; furthermore OeNB supervisory staff is partly from CESEE-countries.

\section{CP 20: Transactions with related parties}

Provisions relating to related party transactions are primarily aimed at protecting shareholders (as reflected by IFRS transparency requirements) and not at contributing to the reduction of supervisory risks. Liability and criminal law provisions also have to be taken into account as well as the fact that in practice, based on our supervisory findings transactions with related parties are not a major concern. According to the current legal regime, any transaction requires unanimous consent of the Board and approval of the Supervisory Board, there is annual reporting about these transactions towards the Supervisory Board, and the Supervisory Board has access to individual cases. The current comprehensive framework is based on experience and external recommendations.

\section{CP 26: Internal Control and Audit}

The assessment does not adequately take into consideration that there is already an explicit legal requirement in Art. 15 and 18 Securities Supervision Act $^{1}$ for all CIs carrying out investment services ${ }^{2}$ to have a compliance function with duties as enshrined in Directive 2004/39/EC (MiFID).

\section{CP 27: Financial Reporting and external audit}

The Austrian authorities would like to draw attention to the fact that the accounting rules and principles of the Company Code (Austrian GAAP) comply with the EC's harmonized accounting standards as defined in the EC's accounting directives (as indicated in EC2):

- $\quad$ Fourth Council Directive 78/660/EEC on the annual accounts of certain types of companies.

- Seventh Council Directive 83/349/EEC on consolidated accounts of certain types of companies.

- $\quad$ EC Regulation 1606/2002 on the application of international accounting standards.

\footnotetext{
${ }^{1}$ Article 18 para. 3 Securities Supervision Act, Article 18 para. 4 no. 2 Securities Supervision Act, Article 15 para. 1 Securities Supervision Act.

${ }^{2}$ According to Article 1 Securities Supervision Act, investment services are defined as reception and transmission of orders in relation to one or more financial instruments, execution of orders on behalf of the client, dealing on own account, portfolio management by way of managing portfolios in accordance with mandates given by clients on a discretionary client-by-client basis where such portfolios include one or more financial instruments, investment advice in relation to financial instruments, underwriting of financial instruments and/or placing of financial instruments on a firm commitment basis, placing of financial instruments without a firm commitment basis, and operation of Multilateral Trading Facilities.
} 
The rules of the EC Regulation are binding in Austria, please see Article 5 of EC Regulation 1606/2002:

Options in respect of annual accounts and of non publicly-traded companies

Member States may permit or require:

a) the companies referred to in Article 4 to prepare their annual accounts,

b) companies other than those referred to in Article 4 to prepare their consolidated accounts and/or their annual accounts,

c) in conformity with the international accounting standards adopted in accordance with the procedure laid down in Article 6(2).

Due to the European regulation, Austrian GAAP are widely accepted in the EC, respectively internationally.

According the preparation of (un-)consolidated financial statements in accordance with IFRS, the Austrian situation can be summarized as follows:

It is a fact that due to the Austrian legislation, Austrian banks have to prepare their unconsolidated financial statements in accordance with Austrian GAAP, whereas consolidated financial statements are usually prepared in accordance with IFRS, binding or on an optional basis. But this fact cannot be connected with the raising of public funds.

There are several ways for banks of raising public funds:

1) Small banks within the banking sectors use Austrian GAAP for their unconsolidated financial statements. Those banks never come in the position of raising public funds, because they will be financed by the rest of the sector.

2) If the whole sector comes in the position of raising public funds, the consolidated financial statements of the sector are prepared in accordance with IFRS.

Also under the aspect of raising public funds, it can be subsumed that financial statements are calculated in accordance with accounting policies and practices that are widely accepted internationally.

Consolidated accounts have to be prepared according to Article 59a Banking Act by using IFRS. According to FINREP consolidated financial statements have to be prepared by using IFRS, beginning in 2014. Also within the COREP-context IFRS will be used if this enhances the data quality of institutions. 